1. Er is weinig verschil tussen de samenstelling en het gedrag van caseïnemicellen in ijsplasma van $-10^{\circ} \mathrm{C}$ en in melk bij kamertemperatuur.

Dit proefschrift

2. Denaturatie van serumeiwitten verloopt langzamer in ijsmix dan in melk. Dit proefschrift

3. Verschillende anionen binden calcium en andere tweewaardige kationen in verschillende mate. Daardoor kan het type zuur dat gebruikt wordt om melk aan te zuren grote invloed hebben op de eigenschappen van caseïnemicellen en daarmee op de fysische eigenschappen van een verzuurd melkproduct.

Dit proefschrift

4. Het effect van calcium op aggregatie van caseïnemicellen in melk bij aanzuren in de kou is tegengesteld aan het effect bij hogere temperaturen: bij aanzuren met GDL bij $3^{\circ} \mathrm{C}$ leidt een verhoging van de calciumionactiviteit tot een verlaagde stevigheid van het gel, bij $50^{\circ} \mathrm{C}$ leidt dit echter tot een steviger gel.

Dit proefschrift

B.Y. Kim and J.E. Kinsella (1989) Rheological changes during slow induced gelation of milk by dgluconic- $\delta$-lactone. Journal of Food Science 54, 894-898.

5. Een oorzaak voor de door Goff et al. (1999) waargenomen clusters van caseïnemicellen in ijs zou thermodynamische incompatibiliteit kunnen zijn.

H.D. Goff, E. Verespej and A.K. Smith (1999) A study of fat and air structures in ice cream International Dairy Journal 9, 817-829.

6. Er is nog relatief weinig bekend over de invloed van verhitting op het gedrag van individuele wei-eiwitten in zuivelproducten. Dit komt vooral doordat er geen goede fysische scheidings- en chemische analysemethoden voor gedenatureerde wei-eiwitten bestaan of doordat de resultaten niet correct worden geïnterpreteerd.

oa C. Holt, D. McPhail, I. Nevison, T. Nylander, J. Otte, R.H. Ipsen, R. Bauer, L. Øgendal, K. Olieman, K. de Kruif, J. Léonil, D. Mollé, G. Henry, J.L. Maubois, M. Dolores Pérez, P. Puyol, M. Calvo, S.M. Bury, G. Kontopidis, I. McNae, L. Sawyer, L. Ragona, L. Zetta, H. Molinari, B. Klarenbeek, M. Jonkman, J. Moulin, D. Chatterton (1999) Apparent chemical composition of nine commercial or semi-commercial whey protein concentrates, isolates and fractions International Journal of Food Science and Technology 34, 543-556

7. Hoewel de ijsindustrie het imago heeft van een innovatieve bedrijfstak, is het ontwerp van een softijsmachine nog steeds zeer ouderwets te noemen.

8. Beslagen ten ijs komen is niet een kenmerk van de meeste wetenschappelijke artikelen over consumptie-ijs.

9. Ondanks het feit dat in veel bedrijven technologie van wezenlijk belang is, is het in weinig van deze bedrijven zo dat toptechnologen even hoog gewaardeerd worden als topmanagers.

10. Gezien het prijsverschil tussen gebotteld water en consumptiemelk, zou het voor de zuivelindustrie economisch interessant kunnen zijn om water uit melk te winnen en te vermarkten. 
11. De bewering van mensen dat ze graag naar verre landen reizen om kennis te maken met een andere cultuur en andere eetgewoonten wordt tegengesproken door het feit dat er in die landen altijd lange rijen Europeanen bij de McDonald's staan en men op reis bij voorkeur elkaars gezelschap zoekt.

12.In Nederland wordt het sociaal vaak niet geaccepteerd dat moeders fulltime werken, terwijl dat voor vaders geen probleem is. Als er in de media gesproken wordt over rechten en privileges van werkende ouders lijkt dat alleen betrekking te hebben op werkende moeders. Deze twee waarnemingen geven aan dat gelijkwaardigheid tussen mannen en vrouwen in het arbeidsproces nog niet in ons denken verankerd is.

13. Vrouwennetwerken zijn de nieuwe vorm van theekransjes.

Stellingen behorende bij het proefschrift "Behaviour of casein micelles at conditions comparable to those in ice cream". Margrethe Jonkman, 7 november 2000. 
Promotor: dr.ir. P. Walstra

emiritus-hoogleraar in de zuivelkunde

Co-promotor: dr.ir. M.A.J.S. van Boekel

universitair hoofddocent, werkzaam bij het departement

Levensmiddelentechnologie en Voedselwetenschappen 


\section{Behaviour of casein micelles at conditions comparable to those in ice cream}




$$
\text { noos? } 201,2824
$$

Margrethe J. Jonkman

Behaviour of casein micelles at conditions comparable to those in ice cream

\section{Proefschrift}

ter verkrijging van de graad van doctor

op gezag van de rector magnificus

van Wageningen Universiteit,

dr.ir. L. Speelman,

in het openbaar te verdedigen

op dinsdag 7 november 2000

des namiddags te vier uur in de Aula. 
ISBN 90-5808-303-9

This research was financed by Unilever Research Colworth, UK. 
Jonkman, M.J. (2000). Behaviour of casein micelles at conditions comparable to those in ice cream.

Ph.D. thesis, Wageningen University, the Netherlands. (pp. 123, English and Dutch summaries).

\title{
Keywords:
}

casein micelles, ice cream, frozen yoghurt, low temperature, freezing, cold aggregation, divalent kations

\begin{abstract}
:
The physical properties of ice cream are mainly determined by the processing and the ingredients. Milk (powder) is one of the ingredients and ice cream thus contains casein, the major milk protein. A large proportion of casein in ice cream is present in the plasma phase of ice cream. Since the behaviour of casein in ice cream plasma was not known and could not be predicted and is expected to be important for the properties of ice cream, the behaviour of casein micelles in ice cream plasma and the influence of several processing steps on its behaviour was studied.

Properties of casein micelles in ice cream plasma obtained at $-10^{\circ} \mathrm{C}$ were studied. Structure and behaviour of the casein micelles did not differ greatly from those in milk. A slightly increased amount of salts was associated with the micelles in ice cream plasma and fewer submicelles and small micelles were present. The increase in size was primarily due to fusion of micelles. The properties of the micelles in ice cream could be explained by the two conditions which differ of milk: high concentration of milk components and low temperature. Preheating did hardly affect the properties of casein micelles in ice cream.

In a model frozen yoghurt plasma nearly all the calcium and inorganic phosphorus was present in the serum. Frozen yoghurt plasma formed a gel during storage, due to aggregation of casein particles. The rheological properties of the gel changed during storage, presumably due to rearrangement of the casein network.

The effects of type of acidulant, addition of various salts, concentration and preheat treatment on aggregation of casein micelles in skim milk in the cold were studied. The $\mathrm{pH}$ of aggregation was strongly influenced by the activity of divalent cations. At $\mathrm{pH} 4.7$ at $3^{\circ} \mathrm{C}$ casein micelles aggregate if the calcium ion activity is $2.5 \mathrm{mM}$ or lower. At higher calcium ion activities the casein micelles appear stable against aggregation. By varying the calcium ion activity of skim milk, the $\mathrm{pH}$ and temperature of aggregation in the cold can be changed.
\end{abstract}


2 Ice cream $\quad 5$

Abstract 5

2.1 Introduction 6

2.2 Constituents $\quad 6$

2.2.1 Fat and fat substitutes $\quad 7$

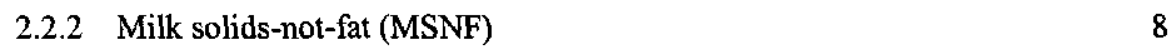

$\begin{array}{lll}2.2 .3 & \text { Sugars } & 9\end{array}$

2.2.4 Emulsifiers 9

$\begin{array}{lll}2.2 .5 & \text { Stabilizers } & 10\end{array}$

$\begin{array}{ll}2.2 .6 & \text { Flavour and colour substances } \\ 2.2 .7 & 10\end{array}$

2.2.7 Water/Ice 11

2.2 .8 Air 11

2.3 Processing 11

2.3.1 Mixing and pasteurizing 11

2.3.2 Homogenizing 12

$\begin{array}{lll}\text { 2.3.3 Ageing } & 13\end{array}$

2.3.4 Freezing and aeration 15

$\begin{array}{ll}\text { 2.3.5 Packaging, hardening and storage } & 16\end{array}$

$\begin{array}{ll}2.4 \text { Microstructure } & 17\end{array}$

$\begin{array}{lll}2.4 .1 & \text { Ice crystals } & 18\end{array}$

$\begin{array}{ll}2.4 .2 \text { Air cells } & 19\end{array}$

$\begin{array}{lll}2.4 .3 & \text { Fat } & 19\end{array}$

2.4.4 Plasma phase 20

References $\quad 20$

3 Casein $\quad 25$

Abstract 25

3.1 Introduction 26

3.2 Casein micelles in milk $\quad 26$

3.3 Heat treatment 29

3.4 Cooling $\quad 30$

3.5 Concentrating 31

3.6 Addition of sucrose $\quad 32$

3.7 Addition of polysaccharides 33

3.7 Acidification 33

3.8 Casein micelles in ice cream $\quad 34$

References $\quad 35$ 
4 Behaviour of casein micelles at conditions comparable to those in ice cream made from low heat milk

Abstract

4.1 Introduction

4.2 Materials and methods

4.2.1 Materials

4.2.2 Separation of the serum phase

4.2.3 Chemical analysis

4.2.4 Measurement of $\mathrm{pH}$ and calcium ion activity

4.2.5 Rheological measurements

4.2.6 Microscopy

4.3 Results and discussion

4.3.1 Salt distribution

4.3.2 $\mathrm{pH}$ and calcium ion activity 51

4.3.3 Rheology

4.3.4 Microscopy

4.4 Conclusions

Acknowledgements

References

5 Effect of preheating on behaviour of casein micelles at conditions comparable to those in ice cream

Abstract

5.1 Introduction

5.2 Materials and methods

5.2.1 Materials

5.2.2 Separation of the serum phase

5.2.3 Chemical analysis

5.2.4 Microscopy

5.2.5 Rheological measurements $\quad 63$

$\begin{array}{lll}\text { 5.2.6 Turbidity measurements } & 63\end{array}$

5.3 Results and discussion

5.3.1 Denaturation of whey proteins in ice cream mix 64

$\begin{array}{lll}\text { 5.3.2 Salt distribution } & 64\end{array}$

5.3.3 Rheology 65

5.3.4 Electron microscopy of ice cream plasma 66

5.3.5 Influence of concentration and heating on casein micelles size 68 distribution in skim milk solutions 
6 Behaviour of casein micelles at conditions comparable to those in frozen yoghurt

Abstract

6.1 Introduction

6.2 Materials and methods

6.2.1 Materials

78

6.2.2 Separation of the serum phase

6.2.3 Chemical analyses

6.2.4 Calcium ion activity

6.2.5 Determination of proteins

6.2.6 Microscopy

6.2.7 Rheological measurements

6.3 Results and discussion

$\begin{array}{ll}6.4 \text { Conclusions } & 88\end{array}$

$\begin{array}{ll}\text { Acknowledgements } & 88\end{array}$

$\begin{array}{ll}\text { References } & 88\end{array}$

7 The effect of various cations on aggregation of casein micelles in the cold 91

Abstract $\quad 91$

7.1 Introduction $\quad 92$

7.2 Materials and methods $\quad 93$

7.2.1 Materials $\quad 93$

7.2.2 Methods 95

7.3 Results and discussion $\quad 96$

$\begin{array}{ll}7.4 \text { Conclusions } & 110\end{array}$

Acknowledgements 111

$\begin{array}{ll}\text { References } & 111\end{array}$

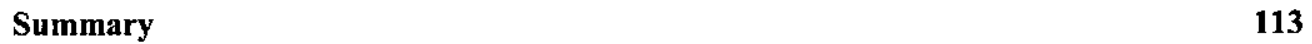

$\begin{array}{ll}\text { Samenvatting } & 117\end{array}$

$\begin{array}{ll}\text { Nawoord } & 121\end{array}$

$\begin{array}{ll}\text { Curriculum vitae } & 123\end{array}$ 
1

Introduction 
Ice cream is a popular dairy dessert and snack consumed all over the world. Important quality attributes of the product are closely related to its physical properties. These properties are mainly determined by the processing and the ingredients. From a scientific and technological point of view, ice cream is a complicated product; several different unit operations are applied, various types of ingredients are used and the resulting product has a complicated structure, being a frozen emulsion as well as a foam dispersed in concentrated, sweetened milk plasma to which polysaccharides are added. Much of the knowledge on relationships between processing, ingredients and physical properties of ice cream is still based on empiricism. However, in-depth knowledge is necessary to be able to forecast and control the physical properties of ice cream. Recently, research on ice cream has increased. This is for instance reflected by the first International Symposium on Ice Cream organised by the International Dairy Federation in 1997. A lot of research is done by the large ice cream companies. Last years also several universities and research institutes have studied ice cream. Excellent work in this field has, for instance, been done by the groups of D. Goff (University of Guelph, Canada) and E. Windhab (ETH, Zurich).

In chapter 2 an overview of the literature on ice cream is given. The liquid phase of ice cream is for the most part derived from milk and thus contains casein, the major milk protein. In milk, casein mostly occurs in colloidal aggregates, called casein micelles. The behaviour of casein micelles is important for the physical properties of milk and milk products. However, little is known of the behaviour of casein in ice cream and its relation with physical properties.

In chapter 3 the behaviour of casein micelles in milk and the influence of several processing steps and conditions are described. Using this knowledge, it was tried to predict the behaviour of casein in ice cream. However, since the conditions in ice cream are so extreme and all the conditions affect the interaction forces between the components of the casein micelles, and often in an opposite direction, it was concluded that it is not possible to predict the behaviour of casein in ice cream.

Since the behaviour of casein in ice cream is not known and hard to predict and since it is expected to be important for the physical properties of ice cream, the behaviour of casein in ice cream should be studied. It is known that casein is present in three structural elements in ice cream: in the plasma phase (i.e the phase surrounding the ice crystals, air bubbles and fat globules), at the fat-plasma interface and at the air-plasma interface. Because some work has been done on behaviour of casein at these interfaces and since the largest part of casein is present in the plasma phase, the main purpose of this work was to study the behaviour of casein in ice cream plasma. This should provide a knowledge base for understanding and influencing the role of casein in the physical properties of ice cream.

The behaviour of casein in a model ice cream plasma at $-10^{\circ} \mathrm{C}$ is described in chapter 4. The main properties studied were the casein micelle size distribution, the voluminosity and the partition of several salts over the micellar and serum phase. 
Since all ice cream mixes are pasteurised or sterilised, results on the influence of a preheating step on the behaviour of casein micelles in ice cream plasma are described in chapter 5. To obtain a better understanding of the phenomena occurring, the influence of concentration and heating on casein micelle size in skim milk solutions was studied also.

The $\mathrm{pH}$ of frozen yogurt is lower than that of ice cream. A decrease in $\mathrm{pH}$ has a large effect on the properties of casein micelles in milk. Therefore the effect of a decrease in $\mathrm{pH}$ on properties of casein micelles in ice cream plasma is studied in chapter 6.

Since some interesting phenomena were observed on acidification of ice cream mix in the cold, aggregation of casein micelles at low temperatures was studied in more detail in chapter 7. Because ice cream mix is rather complicated, milk was used as the system. The influence of type of acidulant, addition of various salts, concentration and preheat treatment on aggregation of casein micelles in milk in the cold is described.

In the summary the results obtained are outlined and general conclusions are drawn. 


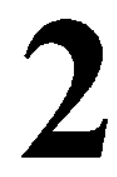

\title{
Ice cream
}

\begin{abstract}
In this chapter an overview of literature on ice cream is given, including a short introduction on the history and the consumption of ice cream. The role, the levels used and the source of the various constituents are reviewed. The processing steps are briefly described, the reason why they are applied and what happens with the various constituents during processing. Finally, the microstructure of ice cream is discussed. Quality aspects of ice cream (e.g. melting resistance, sensory properties) are discussed in the most appropriate sections.

Recently some scientific papers have been published on ice cream, especially on the effect of stabilizers on ice (re)crystallization and on the rearrangements in the fat-plasma interface during ageing. However, most knowledge is based on practical experience or based on knowledge of other dairy products (e.g. cream) and gaps remain in our knowledge. Especially the effects of ingredients and processing on sensory and textural properties are still poorly understood.
\end{abstract}




\subsection{Introduction}

Ice cream is a popular confection and dessert which has been consumed in various forms for hundreds of years. Some literature claims that it is a treat already enjoyed by the Roman Emperor Nero, others allege that it is an invention brought by Marco Polo in the thirteenth century from China. Ice cream as we know it was probably first made during the Renaissance in Italy. In the 17th century ice cream was introduced in Europe on a wider scale. However, it was only affordable by the aristocratic elite. The first wholesale ice cream industry was established in the nineteenth century. In that period ice cream became widely popular. During the last century, the ice cream industry has grown enormously, mainly due to advances in process engineering, such as homogenization and refrigeration, the distribution of frozen products and the mechanization of the production process. In the 1960s a process of business concentration began. This resulted in a rapid decrease in the number of manufacturers (Reinders, 1999). More recently ice cream manufacturers have tried to diversify their products: developing ice cream products for various types of consumers, for various occasions in the day and for various seasons.

Consumption of ice cream varies among continents and countries. In the United States, Australia and Sweden large quantities of ice cream are consumed per capita. The consumption in 1997 was $20.4,18.5$ and 15.8 litres per capita, respectively. In the Netherlands about 7.5 litres per capita is currently consumed. Recently sales in Europe and the United States have hardly increased. However, ice cream becomes more and more an established snack beyond these regions. In the period between 1993 and 1997, sales of ice cream in Asia more than doubled (Reinders, 1999; Voorbergen, 1999).

In the Netherlands in 1998 industrially produced ice cream contributed to about $70 \%$ of ice cream consumption. The market for industrially produced ice cream in 1998 can be divided into impulse ice creams $(18.0 \%)$, foodservice market $(11.6 \%)$ and take home market (multipacks 30.8\%, desserts 39.6\%) (Anonymous, 1999).

Various products may be designated ice cream or ice cream related products; e.g. ice cream, milk ice, frozen yoghurt, sherbets, water ices, soft-serve products. In this thesis "classical" ice cream is taken as typical. As a general term of reference, ice cream may contain by volume $50 \%$ of air and by weight $10 \%$ fat, $11 \%$ solids-not-fat from milk, $15 \%$ added sugar, a few tenths of a per cent stabilizer and emulsifier, and $63.5 \%$ water, most of it in the form of ice crystals.

\subsection{Constituents}

Ice cream is composed of a mixture of food materials such as milk products, sweetening agents, stabilizers, and flavour substances, which are referred to as ingredients. The effect of 
the ingredients on the finished product is due to the constituents of the ingredients and the processing applied. In this section, the role, the levels used and the source of the various constituents in ice cream are described.

\subsubsection{Fat and fat substitutes}

Fat is a constituent of major importance in ice cream. It affects flavour, structure, structural stability and mouthfeel. Fat acts as a flavour carrier for (added) characteristic flavours. Milk fat also contributes to the subtle dairy flavour. The role of fat in the structure and structure stability is largely via the clumping of the fat globules. A partially crystalline fat is necessary for clumping to occur. Clumping is essential for dryness of extrusion, stabilisation of air bubbles and shape retention on melting. When ice cream melts in the mouth the fat produces a characteristic smooth texture by lubricating the palate (Kilara, 1998; Walstra and Jonkman, 1998).

Ice cream usually contains $8-16 \%$ fat by weight. The amount of fat used is mainly limited by its cost. Other limitations on excessive use are hindered whipping ability, reduced consumption of the product due to excessive richness, and high energy value.

Milk is an important ingredient for the manufacture of ice cream. The fat content of milk is, however, too low. Therefore other supplies of fat are required. Fresh cream is the best source of concentrated fat but it is expensive. Other sources are frozen cream, unsalted butter, butter oil, anhydrous milk fat, fractionated milk fat and concentrated milk blends (Marshall and Arbuckle, 1996). Milk fat is a complex mixtures of triacyl glycerides with a wide range in melting points. Between $-30^{\circ} \mathrm{C}$ and $40^{\circ} \mathrm{C}$ there is always a mixture of solid and liquid fat, i.e. oil with various types of crystals (Walstra et al., 1999).

Because of the high cost of milk fat and certain nutritional aspects, ice cream is also manufactured with other fats. They are usually based on mixtures of (partly hydrogenated) vegetable fats. Physical factors of the fat (mixture) that are considered important are the proportion of the fat that is liquid at the time of entry into the freezer and the way in which the fat crystallizes. Besides these physical properties, it is also important that the fats and oils used have bland flavour and odour (Madden, 1989; Berger, 1997).

Especially in the United States there has been an interest to decrease the energy value of ice cream by developing low and non fat products. As a substitute for fat in ice cream several products based on polysaccharides (e.g. starches, cellulosic products, maltodextrins) and proteins (typically derived from whey or egg white) have been developed (Marshall and Arbuckle, 1996). Many studies have been carried out on the effect of fat substitution on ice cream properties (e.g. Ohmes et al., 1998; Roland et al., 1999; Specter and Setser, 1994). Kilara (1998) concluded that presently no ideal fat substitute is available in the marketplace. A combination of substitutes, process technology (e.g. pre-aeration, lower drawing 
temperatures, high pressure homogenization, high displacement dashers) and flavour technology may possibly lead to successful development of low and non fat ice cream.

\subsubsection{Milk solids-not-fat (MSNF)}

The milk solids-not-fat include milk proteins, milk sugar (lactose), and minerals. Ice cream usually contains $8-15 \%$ MSNF. The maximum concentration of MSNF varies somewhat with the conditions under which ice cream is produced and stored. The low solubility of lactose imposes a limit on the proportion of MSNF that can be used satisfactorily in ice cream.

Liquid milk has been mentioned as a source of milk fat but it also contains $9 \%$ MSNF. Additional MSNF is usually added by means of skimmed or whole milk powder, concentrated skim milk, sweetened condensed milk, or buttermilk products. To reduce costs, last years whey powder and whey protein concentrates are also applied. However, at high replacement levels the quality of ice cream diminishes in terms of flavour, firmness, meltdown properties and air bubble size distribution due to insufficient destabilisation of the ice cream emulsion. This may be solved by using other emulsifier/stabilizer combinations or modified whey protein products (e.g. Kokelaar and Lipsch, 1998; Westerbeek, 1996; Westerbeek, 1999).

In ice cream the milk protein content is about $4 \%$. It is thought that the protein in ice cream plays a number of roles, of which the most important ones may be acting as an emulsifier during homogenization and as a foaming agent during the freezing process. Proteins also contribute to the desired high viscosity of the aqueous phase of ice cream (Walstra and Jonkman, 1998). The main protein components of milk are caseins and serum proteins. An overview of the literature on casein is given in chapter 3 . The behaviour of casein micelles in ice cream is hardly known. The aim of this study is to determine and understand the behaviour of casein micelles in the plasma phase of ice cream.

Most ice cream contains about $0.6-0.9 \%$ salts. The main cations present are calcium, potassium, sodium, and magnesium, and the main anions are chloride, phosphate, and citrate. The salts in ice cream mainly come from milk. Sometimes, $\mathrm{NaCl}$ is added to enhance certain flavours, and other salts (citrates, phosphates, calcium and magnesium salts) may be added for various reasons. Part of the salts in milk is dissolved in the serum phase and present as ions or ion pairs. The other, undissolved, part is present in casein micelles as counterions and especially as colloidal calcium phosphate (see section 3.2). According to Hamilton (1983), the salts give a slightly salty taste, which enhances the overall flavour of the ice cream.

The concentration of lactose ranges from 4 to $7 \%$ in ice cream. The role of lactose is the same as of the added sugars (section 2.2.3); lactose reduces the freezing point of the mix and adds to the sweet taste of ice cream which is largely caused by added sugars. Lactose is not very soluble and therefore tends to crystallize. If the lactose crystals become large enough, they cause a gritty texture in the finished product, a defect known as "sandiness". Nickerson 
$(1954,1956,1957,1962)$ investigated factors involved in lactose crystallisation in ice cream. Sandiness is promoted by a high MSNF content, prolonged storage, and by fluctuating storage temperatures. Sandiness was a major problem in the past, but under current manufacturing principles it rarely occurs.

\subsubsection{Sugars}

Sugars are added primarily to increase the acceptance of the product, not only by making it sweeter but also by enhancing the creamy and the fruit flavours. Sugars lower the freezing point of the mix so that there is less ice at a given serving temperature. Besides the amount of ice, sugars may also influence the recrystallization rate of ice crystals. Hagiwari and Hartel (1996) observed a direct relationship between recrystallization rate and freezing point of the mix, but Trgo et al. (1999) did not find a significant effect. In addition to their effect on the quality of the ice cream, sugars are usually the cheapest source of solids in the mix.

Although the sugar most often used is still sucrose, from cane or beet, other sugars are also used. The chief ones are the so called glucose syrups and dextrose. By replacing part of the sucrose by other sugars control of sweetness and freezing point (and hence hardness) can be achieved. In some products, especially in the United States, nonnutritive sweeteners are used to reduce the caloric value.

Sucrose is normally used at a rate between 12 and $15 \%$ in ice cream. Usually not more than $25-35 \%$ of the total sweetener is supplied by corn syrup solids (Marshall and Arbuckle, 1996; Rothwell, 1998).

\subsubsection{Emulsifiers}

The prime role of the emulsifier in ice cream has nothing to do with emulsifying, but to assist in the controlled partial destabilisation of the emulsion in the freezer by displacement of protein from the fat globule surface (section 2.3.3 and 4). The fat destabilisation imparts desirable properties to ice cream (section 2.2.1). Emulsifiers are also important for aeration quality.

Egg yolk used to be a common ice cream emulsifier. Currently, two main types of emulsifiers are used: monoglycerides, and sorbitan esters (spans, polysorbates/tweens). The type of emulsifier used is of major importance for the amount of displaced protein and may possibly have an effect on the amount of fat crystallized (section 2.3.3).

The amount of emulsifier needed depends on the composition of the mix. It is generally agreed that the higher its fat content, the lower the emulsifier level needed. The 
extent of protein displacement is a function of emulsifier concentration relative to the fat globule surface area. The amount of emulsifier in ice cream averages about 0.2 per cent.

\subsubsection{Stabilizers}

Stabilizers perform several functions in ice cream. Their main function is to limit recrystallization of ice crystals during temperature fluctuations. Recently much research has been done to describe and explain the effects of stabilizers on ice recrystallization (Donhowe and Hartel, 1996a,b; Flores and Goff, 1999a,b; Goff et al., 1999; Hagiwari and Hartel, 1996; Miller-Livney and Hartel, 1997; Sahagian and Goff, 1995; Sutton and Wilcox, 1998a,b). It was generally observed that stabilizers have little impact on the initial ice crystal size distribution in ice cream at the time of draw from the scraped surface heat exchanger and also little or no impact on initial ice growth during quiescent freezing and hardening, but they do limit the growth of ice crystals during recrystallization. The mechanism has extensively been studied but is not yet clear. Goff et al. (1999) postulated that reduction in recrystallization results from the formation of a continuous polymer network and structural heterogeneity in the unfrozen phase. During temperature fluctuation, ice melting and growth becomes more favourable within the pore of the network than water diffusion to larger crystals, thus resulting in a preservation of the initial ice crystal size distribution. The recrystallization rate depends on the type and concentration of the stabilizer present. Besides influence on the ice crystal size, stabilizers might also inhibit the growth of sugar crystals.

The second important function of stabilizers is to increase the viscosity of the continuous phase. They thereby contribute to eating characteristics, such as body and creaminess, and to resistance to melting (Berger, 1997; Goff, 1997).

Stabilizers that are commonly used include guar gum, locust bean gum, carrageenans, alginate, carboxymethylcellulose and xanthan. Usually $0.1-0.3 \%$ stabilizer is used in ice cream mix. Each of the stabilizers has its own characteristics and two or more of these stabilizers are often used in combination to improve their overall effectiveness (Marshall and Arbuckle, 1996).

\subsubsection{Flavour and colour substances}

Most ice cream is flavoured by the addition of natural or synthetic substances, such as vanilla, chocolate and cacao, nuts, fruits and fruit extracts.

Colour substances are used to increase the aesthetic appeal of ice cream. They are generally matched with the flavour substances added and would thereby help identifying the flavour (Marshall and Arbuckle, 1996). 


\subsubsection{Water/Ice}

Water present in the ice cream mix comes from liquid dairy products, or from added water. Ice cream mix normally contains $57-64$ per cent water. Water is present as ice crystals and as unfrozen water. The proportion frozen is about $50 \%$ at extrusion temperature $\left(-5\right.$ to $\left.-6^{\circ} \mathrm{C}\right)$, about $90 \%$ at hardening temperature $\left(-30^{\circ} \mathrm{C}\right)$ and about $85 \%$ at storage temperature in a home freezer $\left(-18^{\circ} \mathrm{C}\right)$.

Without unfrozen water, the ice cream would be too hard to scoop and to eat. Ice crystals are essential for consistency and coolness. The low temperature lessens the sweetness. If the water content is low, there is a risk that crystals of the less soluble sugars (especially lactose) will be perceived as 'sandiness' after freezing and storage. With a high water content, problems may occur due to large ice crystals or the melting of the product between unpackaging and consumption (Walstra et al., 1999).

\subsubsection{Air}

The air cells have four main functions. They make the ice cream light; it would be considered too rich without air. They make the ice cream soft and deformable during eating. They isolate against excessive coolness; the ice cream would be too cold in the mouth without air. Another effect of air is to provide a whiter product (Walstra et al., 1999). The content by weight of air in ice cream is about $0.06 \%$. The air content by volume is about $50 \%$ and is in some countries limited by legal regulations. Premium ice cream usually has a lower air content.

\subsection{Processing}

After selecting the ingredients, several process steps are needed to obtain ice cream: (1) mixing, (2) pasteurizing, (3) homogenizing, (4) ageing, (5) freezing, aeration and extrusion, and (6) packaging, hardening and storage. Homogenization can also take place before pasteurization ("up-stream"). In this section the processing steps are briefly described, the reason why they are applied and what happens with the different constituents, especially proteins, during processing.

\subsubsection{Mixing and pasteurizing}

After blending of the liquid and dry ingredients, the ice cream mix is pasteurized. Continuous HTST pasteurization is usually applied with conditions of $82-87^{\circ} \mathrm{C}$ for $15-30 \mathrm{~s}$ (Andreasen and Nielsen, 1992). Pasteurization is compulsory because it destroys pathogenic bacteria. 
Furthermore, most enzymes that could damage flavour and texture are destroyed by pasteurization. The heating also speeds up dissolution of some of the constituents and fat is melted to ensure proper homogenization (Marshall and Arbuckle, 1996). During pasteurization, part of the serum proteins may denature and form aggregates and/or associate with the caseins.

\subsubsection{Homogenizing}

Homogenization of the ice cream mix is essential. As a result of homogenization the size of fat globules is reduced to less than $2 \mu \mathrm{m}$. Homogenization considerably enlarges the fat surface and thus creates denuded fat. The natural membrane cannot spread out appreciably to cover a larger area, though most of it stays at the globules. Surface active molecules (emulsifiers, casein micelles, native and denatured serum proteins) will move to the new fatplasma interface. As homogenization is such a dynamic process, the movement of surface active material to the interface is believed to be by convection rather than by diffusion. This causes an extremely quick coverage and a preferential adsorption of larger species, i.e. casein micelles. They will arrive faster than the smaller serum proteins and polar lipids and are more rapidly adsorbed (Gelin et al., 1994; Walstra and Oortwijn, 1982). Pelan et al. (1997) found in an ice cream mix without emulsifier a surface coverage of $11 \pm 2 \mathrm{mg}$ protein $/ \mathrm{m}^{2}$ after homogenization. Compared to skim milk emulsions the surface coverage is rather high. This could be due to other properties (e.g. size distribution) of casein micelles in ice cream mix compared to in skim milk emulsions.

Homogenization affects milk protein mostly through fat-protein interaction, but another effect can not be ruled out. Walstra (1980) observed that in milk plasma the larger casein micelles are disrupted at a high homogenization pressure. The fragments reassociate with a relaxation time of about 3 minutes, but whether this is in precisely the original form is uncertain.

The net effects of homogenization are in the production of smaller droplets, resulting in a greater stability of fat droplets during ageing, a better whipping ability and a smoother, more uniform final product. Homogenization also decreases the danger of churning the fat in the freezer (Goff, 1997).

The efficiency of homogenization is optimised by using a temperature of $70-75^{\circ} \mathrm{C}$, which ensures that the fat remains liquid and the mix viscosity is not too great (Mulder and Waistra, 1974). The homogenization pressure needed will mainly depend on formulation (percentage of fat, type of fat, total solids content) and equipment used. The higher the fat content and total solids in the mix, the lower the pressure should be. It is common to use a two stage process. First the ice cream mix is homogenized at a pressure of about 10 to 22 $\mathrm{MPa}$. At the end of this treatment it is often found that individual small fat globules cohere in 
clumps, resulting in a very viscous mix which has poor processing properties in subsequent stages (Andreasen and Nielsen, 1992; Madden, 1989; Berger, 1997). These clusters arise due to two fat globules sharing one or more casein micelles in their interface (Mulder and Walstra, 1974). A second homogenizing stage at a lower pressure such as $3.5 \mathrm{MPa}$ is used to break up the clusters (Berger, 1997). Since casein micelles spread more rapidly over the fat-serum interface at higher temperatures, a high homogenization temperature also aids to prevent formation of homogenization clusters (Walstra et al., 1999).

\subsubsection{Ageing}

After homogenization, the mix is cooled to about $5^{\circ} \mathrm{C}$ and left for ageing for about 2 up to 24 hours. Practical experience has indicated a better quality product is obtained after an ageing period. Ice cream from a non-aged mix exhibits poor standup, is very wet at extrusion, and exhibits variable whipping abilities. The whipping qualities of the mix are usually improved with ageing (Goff, 1997). The following and possibly other processes may occur during ageing: (1) rearrangements in the fat-plasma interface, (2) crystallization of liquid fat, and (3) swelling of stabilizers and milk proteins.

Several studies have been carried out on the rearrangement of the fat-plasma interfacial layer (Abd El-Rahman et al., 1997; Barfod et al., 1991; Buchheim and Dejmek, 1997; Gelin et al., 1994; Goff et al., 1987; Goff and Jordan, 1989; Pelan et al., 1997). With the exception of the study of Abd El-Rahman et al. (1997), it was observed that the amount of protein adsorbed on the fat globules in ice cream mix decreased during ageing. In the presence of emulsifiers a more complete desorption of protein at the interfaces will take place. Pelan et al. (1997) showed that in ice cream mix Tween 60 was much more effective in displacing protein than were monoglycerides. Barfod et al. (1991) observed that among the monoglycerides partially unsaturated monoglycerides (GMO) were more effective than saturated monoglycerides (GMS). This could not be confirmed by Pelan et al. (1997). As a result of desorption of protein the fat globules become more susceptible to coalescence induced by the shear forces during freezing and aeration. As expected by the protein adsorption results, Tweens gave a stronger destabilization of ice cream mixes than monoglycerides. Among the monoglycerides GMO destabilized the mixes stronger than GMS (Barfod et al., 1991; Goff and Jordan, 1989; Pelan et al., 1997). Destabilisation of fat is of major importance for some properties of ice cream (see section 2.2.1).

Barfod et al. (1991) suggest that the effect of ageing on monoglycerides is due to their strong interfacial activity at low temperature. They observed that at high temperatures the monoglycerides reduce the surface tension of the oil/water interface a little. However, the interfacial activity of monoglycerides increases dramatically at low temperature. The interfacial tension decreases to values below that of the protein film, and, consequently, 
monoglycerides may displace protein molecules. The low interfacial tension of surfactants at low temperature was described many years ago by Lutton et al. (1969). They proposed that the effect is due to crystallization of the hydrophobic carbon chains in the monomolecular layer of emulsifier adsorbed at the interface. Due to chain crystallization the surface concentration of emulsifier would increase, leading to a decrease in surface tension. Barfod $e t$ al. (1991) did not measure the interfacial activity of Tweens at low temperatures. However, it is not expected that temperature has such a pronounced effect on the surface activity of Tweens. Goff and Jordan (1989) compared the interfacial tensions of six emulsifiers (Tweens, Spans, GMO, GMS) at oil/skim milk solution interfaces. However, these measurements were performed at $70^{\circ} \mathrm{C}$ and these results cannot probably be used to explain the behaviour of these emulsifiers at $5^{\circ} \mathrm{C}$.

The desorption of protein may also partly be due to some characteristics of casein micelles. When the temperature is lowered hydrophobic interactions become much weaker, and part of the casein, particularly of the $\beta$-casein, dissociates from the micelles. The voluminosity of the micelles increases, probably in part from increased "hairiness", as $\beta$ casein may protrude from the micelle surface. A small part of the calcium phosphate dissolves. These changes may be a cause of desorption and slight disintegration of the micelles (Barfod et al., 1991; Walstra et al., 1999).

Cooling to $5^{\circ} \mathrm{C}$ induces crystallization within the fat droplets of the mix. Barfod et al. (1991) observed that most of the fat crystallization in ice cream mix usually takes place within an hour, but that it proceeds at a slower rate for several hours. Pelan et al. (1997) did not observe an effect of emulsifiers on fat crystallization. However, Barfod et al. (1991) and Abd El-Rahman et al. (1997), showed that in the presence of some emulsifiers, the degree of crystallization is increased resulting in higher solid fat contents, GMS being more effective than GMO. Fat crystallization was not affected by polysorbates. The influence of monoglycerides on crystallization of fat might be explained by the observation that the orientated fatty-acid chains of adsorbed emulsifier molecules can act as nucleation sites for crystallization of the glycerides of high melting point (Dickinson and Stainsby, 1982). The fat crystallization causes distortion of the initial spherical globule shape, which in combination with partial desorption of protein, may result in enhanced partial coalescence of fat globules during freezing (Dickinson, 1992; Goff and Jordan, 1989).

The stabilizers and other macromolecules may further swell during ageing. Therefore the viscosity of the mix increases somewhat. Optimum functionality of the stabilizers is only realised after complete hydration. This may enable the polymer chains to interact and to form a very viscous or gelled aqueous phase. However, the importance of ageing will vary among stabilizers. For instance, sodium carboxymethyl cellulose hydrates completely in the original mix solution and is not affected by ageing, whereas gelatin needs an ageing period of 5 to 10 hours (Berger, 1997). 


\subsubsection{Freezing and aeration}

After ageing, the ice cream mix is frozen and aerated in a scraped-surface heat exchanger. Besides freezing and aeration, another important process takes place during this step: partial coalescence of fat globules. In a continuous freezer air is drawn into the mix by vacuum or injected under pressure. After 0.4 to $2 \mathrm{~min}$ freezing the ice cream reaches a certain consistency and it is discharged at a temperature of -5 to $-6^{\circ} \mathrm{C}$. At this time, the ice cream contains the desired amount of air ( $50 \%$ by volume), but not the desired amount of ice crystals.

The objective of the freezing process is to form very small ice crystals through control of ice nucleation and growth. Ammonia vaporizing on the outside of the freezer barrel provides a refrigeration effect to cool the ice cream below its freezing point $\left(-2\right.$ to $\left.-3^{\circ} \mathrm{C}\right)$ and cause nucleation, or the formation of small ice crystals. Ice crystals are continuously scraped form the region near the wall and dispersed into the bulk of the mix. Here, ice crystal nuclei grow and "ripen" into block shape crystals. By formation of pure ice crystals the sugar and the other solutes become more concentrated. Increasing the concentration of these solutes causes the freezing point of the liquid portion to be lower, so that the temperature must be lowered before more ice crystals will form. Ice cream leaving a standard freezer at -5 to $-6^{\circ} \mathrm{C}$ will have about $50 \%$ of its water content as ice. The mean size of the ice crystals at this moment is $30-35 \mu \mathrm{m}$, depending on conditions in the freezer. The most important conditions influencing the ice crystal size are: type of freezer, intensity of mixing within the freezer, type of dasher, dasher speed, scraper-blade sharpness and draw temperature (Hartel, 1996).

Air bubbles are beaten in and broken up into smaller ones. Coalescence of air bubbles also occurs, until an approximately steady state is reached. Air being incorporated into the mix is initially stabilized by a layer of adsorbed milk protein, but then there is secondary adsorption of fat globules with the air-plasma interface (Anderson and Brooker, 1988). Aeration is dependent on mixing and freezing parameters, on the foaming properties of the mix components (proteins, emulsifiers) and the rheology of the mix. Aeration studies on model ice cream have shown that the mix viscosity should be so high as to prevent entrained air from rapidly creaming before it can be sheared to produce smaller gas cells. If the mix viscosity is too high, much of the mechanical energy, required to shear large gas cells, is dissipated into heat and the air is not broken up into small gas cells and is difficult to retain (Turan, 1997).

During freezing and aeration the emulsion is subjected to very high stresses. A combination of air, applied shear stress (from the dashers and scraper blades), and ice formation all contribute to partial coalescence. Fat globules will collide with great force and at a high rate. Fat crystals may distort the surface of the fat globules. These distortions can pierce the film between two colliding globules and clumping of fat globules takes place. Part of the liquid oil in some of the globules may flow out and spread over the air surface. The 
network of crystals in the globules prevents their complete coalesce into bigger ones; instead irregularly shaped clumps are formed. The fat globule clusters formed are responsible for surrounding and stabilising the air cells and creating a semi-continuous or matrix of fat throughout the product (Goff, 1997; Walstra and Jonkman, 1998).

A certain amount of fat clumping is desirable in order to obtain a 'dry' product, good shape retention, slow melt down, and a firm texture. Excessive partial coalescence, however, is undesirable and is associated with poor whipping properties, unsatisfactory extrusion, a buttery texture, and a 'does not melt' defect accompanied by separation of some thin watery serum (Berger and White, 1971). It is clear, therefore, that an optimum degree of clumping is needed, and in practice most manufacturers aim at producing a controlled amount of partial coalescence in the freezer (Berger, 1972a). The conditions during freezing and aeration (dasher capacity, dasher speed, extrusion temperature) will have a great influence on partial coalescence and hence on ice cream properties (Kokubo et al., 1996, 1998; Sakurai et al., 1996).

The amount of protein adsorbed at the fat surface is lower in thawed ice cream than in ice cream mix after ageing. The decrease in protein load is attributed to several reactions occurring during freezing and aeration (Barfod et al., 1991; Gelin et al., 1994).

Recently, Windhab and co-workers (e.g. Windhab and Bolliger, 1998) developed a low temperature freezing and aeration process, existing of three steps: pre-aeration, freezing and extrusion. This enables ice cream outlet temperatures below $-15^{\circ} \mathrm{C}$ and consequently packaging without hardening. Ice cream extruded at such low temperatures has been shown to yield a more finely dispersed microstructure and improved organoleptic properties.

\subsubsection{Packaging, hardening and storage}

When ice cream is drawn from the freezer, particulate matter (e.g. fruit pieces) can be added to the ice cream. After they have been added, the product is put into containers and hardened. "Novelties" are frozen in molds or extruded. Packaging of novelties can take place before or after hardening.

During hardening the temperature of ice cream is further reduced to -25 to $-30^{\circ} \mathrm{C}$. About $85-90 \%$ of the water is frozen at the end of the hardening stage. Since during hardening the supercooling does rarely reach a level at which nucleation can occur, the ice continues to form only by further growth of crystals. The number of ice crystals decreases during the hardening, which shows that recrystallization (Ostwald ripening and/or accretion) must occur (Cebula and Russell, 1998). The initial freezing should be fast to keep ice crystal size small and to maintain a fine foam. During hardening the fat continues to crystallize and the unfrozen plasma phase is further concentrated. 
After hardening, ice cream is generally stored at about -18 to $-25^{\circ} \mathrm{C}$ and is then rather stable with respect to chemical and enzymatic reactions and with respect to physical structure changes for some months (Berger, 1997; Marshall and Arbuckle, 1996). Since the glass transition temperature $T_{g}$ ' of ice cream mix would be about $-30^{\circ} \mathrm{C}$ (Goff et al., 1993) and the temperature during storage is usually above it, ice may recrystallize leading to larger crystals. If ice crystal size increases above a formulation dependent threshold the crystals become detectable by the consumer. Recrystallization rate increases with storage temperature and extent of temperature fluctuation (Donhowe and Hartel, 1996b) and depends on type and concentration of stabilizer present (see section 2.2.5). Hagiwari and Hartel (1996) observed at a given temperature a direct relationship between recrystallization rate and freezing point of the mix, but Trgo et al. (1999) did not find a significant effect.

Lactose may also crystallize and become detectable during poor storage conditions (see also section 2.2.2).

Low storage temperatures are also required to ensure that the foam does not continue to deteriorate, since the air bubbles are subject to Ostwald ripening. Air will diffuse from smaller to larger bubbles, causing the disappearance of small and the growth of large bubbles. Too large air cells might lead to a coarse and fluffy structure (Walstra and Jonkman, 1998). Another problem which may occur during transportation from low to high altitudes or vice versa is shrinkage of the product. This defect results from the escape of air that has been freed by the collapse of air cells. Several factors that decrease and increase shrinkage are reported by Dubey and White (1997).

\subsection{Microstructure}

A great deal of the knowledge about the microstructure of ice cream has been acquired, by the electron microscopical studies of Berger et al. (1971, 1972a,b) and Caldwell et al. (1992a,b). Micrographs of ice cream revealed four types of structural elements: ice crystals, air cells, fat globules, and a continuous plasma phase containing dissolved and/or colloidal sugars, salts, proteins and stabilizers (Caldwell, 1992a). The microstructure is illustrated in figure 2.1. In this chapter the four structural elements will be discussed. 


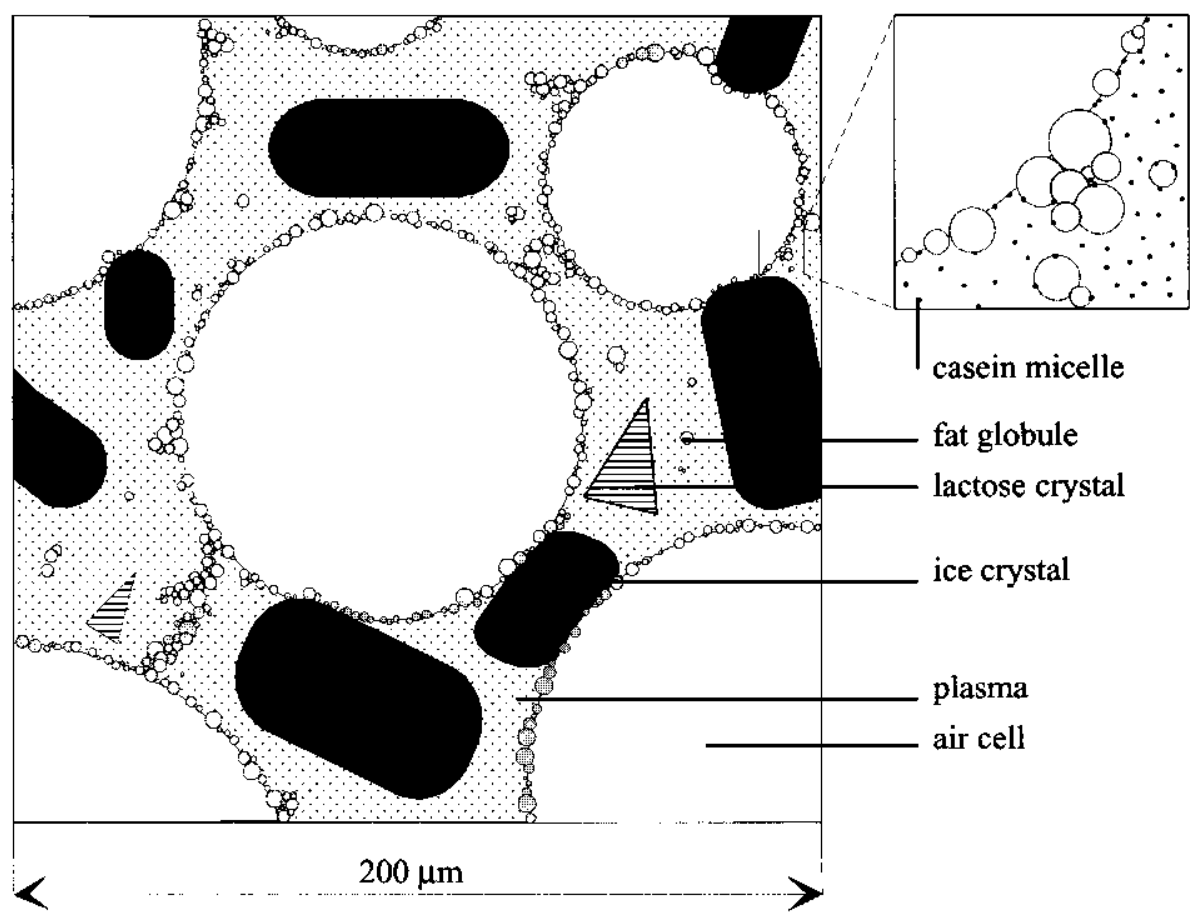

Fig. 2.1. Microstructure of ice cream at $-5^{\circ} \mathrm{C}$; highly schematic (Walstra and Jonkman, 1998)

\subsubsection{Ice crystals}

The volume fraction of ice crystals at $-5^{\circ} \mathrm{C}$ is 0.16 , at $-18^{\circ} \mathrm{C} 0.27$. The number of ice crystals per litre ice cream is approximately $4 \times 10^{9}$ (Nielsen, 1973). The diameter of ice crystals in ice cream ranges from 20-130 $\mu \mathrm{m}$, with a mean value of about 40 to $50 \mu \mathrm{m}$ (Berger, 1997; Caldwell et al., 1992a). The size of and the interactions between the ice crystals are one of the major factors governing the texture of ice cream. If a significant proportion of the ice crystals is larger than about $55 \mu \mathrm{m}$, the texture is judged as coarse and icy (Berger, 1972a). The size and the shape of the crystals is mainly governed by composition of the mix (stabilizers, freezing point), conditions during freezing and aeration, the rate of freezing in the hardening room and the temperature history during storage (Hartel, 1996) (see also sections 2.2.3, 2.2.5, 2.3.4 and 2.3.5). Recently also studies are reported in which anti-freeze proteins are added to ice cream to control ice crystal size (Wichers et al., 1998). This is however not yet commercially applicable. 


\subsubsection{Air cells}

The volume fraction of air is about $50 \%$ in most types of ice cream. About $4 \times 10^{9}$ air cells are present in one litre of ice cream (Nielsen, 1973). Many different figures have been given in the literature for the mean diameter of air cells in ice cream, and the values range from 5 to $250 \mu \mathrm{m}$. The mean air cell diameter should be of the order of $30 \mu \mathrm{m}$. If air cells are too large, the texture is snowy or flaky and the ice cream seems to melt too quickly. On the other hand, if the air cells are too small, the foam becomes too stable, and an undesirable 'head' is left after melting (Berger and White, 1979; Dickinson, 1992).

Electron microscopical studies showed that air bubbles are spherical (Caldwell et al., 1992a). Buchheim and Dejmek (1997) observed that in the absence of surfactants air cells are stabilized by a thin protein film only and that there are almost no fat globules adsorbed at the air cells. In the presence of surfactants the interface is lined with many fat globules which protrude into the air cells. It is also believed that a thin layer of oil additionally lines the air cells (Berger and White, 1979). Although no protein has been observed at the air-plasma interface, it is to be expected that, like in cream (Anderson and Brooker, 1988), some surface layer of protein is found at the interface.

\subsubsection{Fat}

The volume fraction of fat globules and clusters in ice cream is about 0.05 . In 1 litre of ice cream about $5 \times 10^{14}$ fat globules are present (Nielsen, 1973). The fat globule diameter in ice cream ranges from 0.05 to $3.0 \mu \mathrm{m}$, with a mean diameter of $0.5 \mu \mathrm{m}$ (Berger, 1997; Caldwell et al., 1992a). The fat globules in ice cream are situated at three places: (1) at the air-plasma interface, (2) in a network of clumped (and clustered) fat globules in the plasma phase, and (3) free in the plasma phase.

Goff et al. (1987) observed on electron micrographs needle-like crystals which are distributed throughout the fat globules. Several fat globules exhibited crystals that appeared to influence the spherical shape of the globule. These crystals may be able to pierce the film between two existing droplets upon close approach, thus promoting rupture of the globule membrane and subsequent partial coalescence. Berger and White (1976) observed in fat globules a crystalline shell composed of the high-melting glycerides and a core of noncrystalline material. This is however less likely and could also not be observed by Goff $e t$ al. (1987).

Each fat globule is surrounded by a membrane, whose composition and structure are of practical importance. The substances competing for a position at the fat-plasma interface are casein micelles, (partially) denatured serum proteins, water, fragments of the natural 
membrane, emulsifiers and high-melting tri-glycerides. Depending on the ingredients and processing the composition of the membrane will vary, but in most cases the fat globules will be coated by a combined protein-emulsifier layer. According to Bergenståhl and Claesson (1997) the fat globule membrane consists, besides an inner layer of milk proteins and emulsifier, also of an adsorbed outer layer which is made up of polysaccharides and water.

\subsubsection{Plasma phase}

The plasma phase of ice cream surrounds the ice crystals, air bubbles and fat globules and results from a freeze-concentration process as water is removed from the solution in the form of ice. The volume fraction of the plasma phase at $-5^{\circ} \mathrm{C}$ is approximately 0.29 , at $-18^{\circ} \mathrm{C} 0.18$. Ice cream plasma contains water, sugars, salts, proteins and water soluble additives like stabilizers. In normal ice cream the sucrose and lactose are in a non-crystalline form (Berger et al., 1972b). Only very occasionally sucrose crystals can be found, and these are very small, ranging from $40 \mathrm{~nm}$ to $160 \mathrm{~nm}$ in size. In ice cream both $\alpha$-lactose monohydrate and $\beta$-lactose crystals may be found. If the crystals are more than $25 \mu \mathrm{m}$ in size, they cause a sandiness in texture (Berger and White, 1979).

At storage temperatures the plasma phase of ice cream is usually a viscoelastic liquid with a very high viscosity and not an amorphous solid (glass). It has been observed that the glass transition temperature for stabilized ice cream mix is approximately $-30^{\circ} \mathrm{C}$ (Goff et al., 1993).

The behaviour of casein micelles in the plasma phase of ice cream will be discussed in section 3.9 .

\section{References}

Abd El-Rahman, A.M., Madkor, S.A., Ibrahim, F.S. and Kilara, A. (1997) Physical characteristics of frozen desserts made with cream, anhydrous milk fat, or milk fat fractions. Journal of Dairy Science 80, 19261935.

Andersen, M. and Brooker, B.E. (1988) Dairy Foams. In Advances in food emulsions and foams, eds. E. Dickinson and G. Stainsby. Elsevier Applied Science, London, pp. 221-255.

Andreasen, T.G. and Nielsen, H. (1992) Ice Cream and aerated desserts. In The technology of dairy products, ed. R. Early. VCH Publishers Inc, New York, pp. 197-220.

Anonymous (1999) IJsconsumptie in Nederland flink gedaald. Consudel, juni 1999, 39.

Barfod, N.M., Krog, N., Larsen, G. and Buchheim, W. (1991) Effects of emulsifiers on protein-fat intercation in ice cream mix during ageing. 1. Quantitative Analyses. Fat Science Technology 93, 24-35. 
Bergenståhl, B.A. and Claesson, P.M. (1997) Surface forces in emulsions. In Food emulsions, eds. K. Larsson and S.E. Friberg. Marcel Dekker Inc., New York, third edition.

Berger, K.G. and White, G.W. (1971) An electron microscopical investigation of fat destabilization in ice cream. Journal of Food Technology 6, 285-294.

Berger, K.G., Bullimore, B.K., White, G.W. and Wright, W.B. (1972a) The structure of ice cream-Part 1. Dairy Industries 37,493-497.

Berger, K.G., Bullimore, B.K., White, G.W. and Wright, W.B. (1972b) The structure of ice cream -Part 2. Dairy Industries 37, 419-425.

Berger, K.G. and White, G.W. (1976) The fat globule membrane in ice cream. Part 2. Emulsifiers and highmelting triglycerides. Dairy Industries International 41, 236-243.

Berger, K.G. and White, G.W. (1979) Ice cream. In Food Microscopy, ed. J.G. Vaughan. Academic Press, London, pp. 499-530.

Berger, K.G. (1997) Ice cream. In Food emulsions, eds. K. Larsson and S.E. Friberg. Marcel Dekker Inc., New York, third edition, pp. 413-490.

Buchheim, W. and Dejmek, P. (1997) Milk and dairy-type emulsions. In Food emulsions, eds. K. Larsson and S.E. Friberg. Marcel Dekker Inc., New York, third edition, pp. 235-278.

Caldwell, K.B., Goff, H.D. and Stanley, D.W. (1992a) A low-temperature scanning electron microscopy study of ice cream. 1. Techniques and general microstructure. Food Structure 11, 1-9.

Caldwell, K.B., Goff, H.D. and Stanley, D.W. (1992b) A low-temperature scanning electron microscopy study of ice cream. 2. Influence of selected ingredients and processes. Food Structure 11, 11-23.

Cebula, D.J. and Russell, A.B. (1998) Ice crystallization control in ice cream. In Ice cream, ed. W. Buchheim. IDF. Proceedings of the International Symposium held in Athens, Greece, 18-19 September 1997, Brussels, pp. 131-140.

Dickinson, E. and Stainsby, G. (1982) Colloids in food. Applied Science Publishers, London.

Dickinson, E. (1992) An introduction to Food Colloids. Oxford University Press, Oxford.

Donhowe, D.P. and Hartel, R.W. (1996a) Recrystallization of ice in ice cream during controlled accelerated storage. International Dairy Journal 6, 1191-1208.

Donhowe, D.P. and Hartel, R.W. (1996b) Recrystallization of ice during bulk storage of ice cream. International Dairy Journal 6, 1209-1221.

Dubey, U.K. and White, C.H. (1997) Ice cream shrinkage: A problem for the ice cream industry. Journal of Dairy Science 80, 3439-3444.

Flores, A.A. and Goff, H.D. (1999a) Ice crystal size distributions in dynamically frozen model solutions and ice cream as affected by stabilizers. Journal of Dairy Science 82, 1399-1407.

Flores, A.A. and Goff, H.D. (1999b) Recrystallization in ice cream after constant and cycling temperature storage conditions as affected by stabilizers. Journal of Dairy Science 82, 1408-1415.

Gelin, J.L., Poyen, L., Courthaudon, J.L., Le Meste, M. and Lorient, D. (1994) Structural changes in oil-in-water emulsions during the manufacture of ice cream. Food Hydrocolloids 8, 299-308. 
Goff, H.D., Liboff, M., Jordan, W.K. and Kinsella, J.E. (1987) The effects of polysorbate 80 on the fat emulsion in ice cream mix: evidence from transmission electron microscopy studies. Food Microstructure 6, 193 198.

Goff, H.D. and Jordan, W.K. (1989) Action of emulsifiers in promoting fat destabilisation during the manufacture of ice cream. Journal of Dairy Science 72, 18-29.

Goff, H.D., Caldwell, K.B., Stanley, D.W. and Maurice, T.J. (1993) The influence of polysaccharides on the glass transition in frozen sucrose solutions and ice cream. Journal of Dainy Science 76, 1268-1277.

Goff, H.D. (1997) Colloidal aspects of ice cream - a review. International Dairy Journal 7, 363-373.

Goff, H.D., Ferdinando, D. and Schorsch, C. (1999) Fluorescence microscopy to study galactomannan structure in frozen sucrose and milk protein solutions. Food Hydrocolloids 13, 353-362.

Hagiwara, T. and Hartel, R.W. (1996) Effect of sweetener, stabilizer, and storage temperature on ice recrystallization in ice cream. Journal of Dairy Science 79, 735-744.

Hamilton, M.P. (1983) Use of milk and milk products in ice cream. Society of dairy technology, Huntingdon Cambs. Proceedings of symposium "Ice Cream", 19-20 October 1981.

Hartel, R.W. (1996) Ice crystallization during the manufacture of ice cream. Trends in Food Science and Technology 7, 315-321.

Kilara, A. (1996) Fat mimetics in ice cream and frozen dessert manufacture. In Ice cream, ed. W. Buchheim. IDF, Proceedings of the International Symposium held in Athens, Greece, 18-19 September 1997, Brussels, pp. 65-74.

Kokelaar, A. and Lipsch, M. (1998) Application of emulsifiers in high whey ice cream. Poster presented at the symposium "Dairying behind the Dikes", the Netherlands, September 1998.

Kokubo, S., Sakurai, K., Hakamata, K., Tomita, M. and Yoshida, S. (1996) The effect of manufacturing conditions on the de-emulsification of fat globules in ice cream. Milchwissenschaft 51, 262-265.

Kokubo, S., Sakurai, K., Iwaki, S., Tomita, M. and Yoshida, S. (1998) Agglomeration of fat globules during the freezing process of ice cream manufacturing. Milchwissenschaft 53, 206-209.

Krog, N. (1998) The use of emulsifiers in ice cream. In Ice cream, ed. W. Buchheim. IDF, Proceedings of the International Symposium held in Athens, Greece, 18-19 September 1997, Brussels, pp. 37-44.

Lutton, E.S., Stauffer, C.E., Martin, J.B. and Fehl, A.J. (1969) Solid and liquid monomolecular film at $0 \mathrm{il} / \mathrm{H}_{2} \mathrm{O}$ interfaces. Journal of Colloid and Interface Science 30, 283-290.

Madden, J.K. (1989) Ice cream. InFoams: Physics, chemistry and structure, ed. A.J. Wilson. Springer-Verlag, London, pp. 184-196.

Marshall, R.T. and Arbuckle, W.S. (1996) Ice cream. Chapman \& Hall, New York, fifth edition.

Miller-Livney, T. and Hartel, R.W. (1997) Ice recrystallization in ice cream: Interactions between sweeteners and stabilizers. Journal of Dairy Science 80, 447-456.

Mulder, H. and Walstra, P. (1974) The milk fat globule. Emulsion science as applied to milk products and comparable foods. Pudoc, Wageningen.

Nickerson, T.A. (1954) Lactose crystallization in ice cream. I. Control of crystal size by seeding. Journal of Dairy Science 37, 1099-1105. 
Nickerson, T.A. (1956) Lactose crystallization in ice cream. II. Factors affecting rate and quantity. Journal of Dairy Science 39, 1342-1350.

Nickerson, T.A. (1957) Lactose crystallization in ice cream. III. Mode of action of milk powder in preventing sandiness. Journal of Dairy Science 40, 309-313.

Nickerson, T.A. (1962) Lactose crystallization in ice cream. IV. Factors responsible for reduced incidence of sandiness. Journal of Dairy Science 45, 354-359.

Nielsen, B.J. (1973) Building and formation of ice cream microstructure during processing. Modern Dairy, May 1973, 10-12.

Ohmes, R.L., Marshall, R.T. and Heymann, H. (1998) Sensory and physical properties of ice creams containing milk fat or fat replacers. Journal of Dairy Science 81, 1222-1228.

Pelan, B., Watts, K.M., Cambell, I.J. and Lips, A. (1997) The stability of aerated milk protein emulsions in the presence of small molecule surfactants. Journal of Dainy Science 80, 2631-2638.

Reinders, P. (1999) Ice cream in the Netherlands. Netherlands Association of the Ice Cream Industry, Zoetermeer.

Roland, A.M., Philips, L.G. and Boor, K.J. (1999) Effects of fat replacers on the sensory properties, color, melting, and hardness of ice cream. Journal of Dairy Science 82, 2094-2100.

Rothwell, J. (1998) Sugars and other sweeteners for ice cream and frozen desserts. In Ice cream, ed. W. Buchheim. IDF, Proceedings of the International Symposium held in Athens, Greece, 18-19 September 1997, Brussels, pp.46-53.

Sahagian, M.E. and Goff, H.D. (1995) Influence of stabilizers and freezing rate on the stress relation behaviour of freeze-concentrated suctose solutions at different temperatures. Food Hydrocolloids 9, 181-188.

Sakurai, K., Kokubo, S., Hakamata, K., Tomita, M. and Yoshida, S. (1996) Effect of production conditions on ice cream melting and hardness. Milchwissenschaft 51, 451-454.

Specter, S.E. and Setser, C.S. (1994) Sensory and physical properties of a reduced-calorie frozen dessert system made with milk fat and sucrose substitutes. Journal of Dairy Science 77, 708-717.

Sutton, R.L. and Wilcox, J. (1998a) Recrystallization in model ice cream as affected by stabilizer concentration. Journal of Food Science 63, 9-11.

Sutton, R.L. and Wilcox, J. (1998b) Recrystallization in ice cream as affected by stabilizers. Journal of Food Science 63, 104-110.

Trgo, C., Koxholt, M. and Kessler, H.G. (1999) Effect of freezing point and texture regulating parameters on the initial ice crystal growth in ice cream. Journal of Dairy Science 82, 460-465.

Turan, S. (1997) Ice cream: A frozen foam. IOP Magazine 4, no 2, 10-11

Voorbergen, M. (1999) Afzet van consumptie-ijs blijft wereldwijd groeien. Zuivelzicht 91, 10 maart '99, 28-29.

Walstra, P. (1980) Effect of homogenization on milk plasma. Netherlands Milk and Dairy Journal 34, 181-190.

Walstra, P. and Oortwijn, H. (1982) The membranes of recombined fat globules. 3. Mode of formation. Netherlands Milk and Dairy Journal 36, 103-113.

Walstra, P., Geurts, T.J., Noomen, A., Jellema, A. and Van Boekel, M.A.J.S. (1999) Dairy Technology. Principles of milk properties and processes. Marcel Dekker Inc., New York. 
Walstra, P. and Jonkman, M.J. (1998) The role of milkfat and protein in ice cream. In Ice cream, ed. W. Buchheim. IDF, Proceedings of the International Symposium held in Athens, Greece, 18-19 September 1997, Brussels, pp. 17-24.

Westerbeek, H. (1996) Milk proteins in ice cream. Dairy Industries International, June 1996, 21-24.

Westerbeek, J.M.M. (1999) Ingrediënten op maat voor luchtige desserts en ijsproducten. Voedingsmiddelentechnologie 32, $\mathrm{nr} 24,19-21$.

Wichers, H.J., Kreuwels and Stolle-Smits, T. (1998) IJs lekkerder met antivrieseiwitten, Voedingsmiddelentechnologie 32, $\mathrm{nr} 22,26-27,50$.

Windhab, E.J. and Bolliger, S. (1998) New developments in ice cream freezing technology and related on-line measuring techniques. In Ice cream, ed. W. Buchheim. IDF, Proceedings of the International Symposium held in Athens, Greece, 18-19 September 1997, Brussels, pp. 112-131. 


\title{
Casein
}

\begin{abstract}
Hardly any research has been done on the behaviour of casein micelles in ice cream. A lot of research has been done on the behaviour of casein micelles in milk and on the influence of processing conditions thereon. This information can be used to try to predict the behaviour of casein micelles in the plasma phase of ice cream. Therefore, a brief overview of the literature on casein in milk is given. The effects of heating, cooling, concentrating, addition of sucrose, addition of polysaccharides, and lowering $\mathrm{pH}$ are described. This provides some insight in the factors that may play a role in the behaviour of the micelle in ice cream. However, since all of these variables affect the interactions between the components, and often in different directions, it was concluded that it is not possible to predict the behaviour of casein micelles in ice cream plasma.
\end{abstract}




\subsection{Introduction}

Milk contains about $3.25 \%$ protein. The proteins in milk can be classified into two main groups, caseins and serum proteins. The serum proteins (often called whey proteins) comprise about $20 \%$ of the protein in milk and are for the most part globular proteins. They include $\beta$ lactoglobulin, $\alpha$-lactalbumin, serum albumin and immunoglobulins. Casein is defined as the protein precipitating from milk near $\mathrm{pH}$ 4.6. The principal casein fractions are $\alpha_{\mathrm{s} 1^{-}}, \alpha_{\mathrm{s} 2^{-}}, \beta-$ and $\kappa$-casein.

Much is known about the behaviour of casein in milk. As mentioned in section 2.2.2 the behaviour of casein in the plasma phase of ice cream is largely unknown. However, the influence of some of the processing steps during ice cream manufacture and some of the conditions that are prevalent in ice cream on casein micelles in milk is known to some extent. The processing steps which may affect the behaviour of micelles in the plasma phase are heating, ageing and freezing. The final conditions are low temperature, high sugar concentrations, a concentrated system and, in frozen yoghurt, a low $\mathrm{pH}$. The aim of this chapter is to see what is known of the influence of these processing steps and final conditions on the behaviour of casein micelles in milk and by means of these results try to predict what will happen with casein micelles in ice cream. Therefore first the behaviour of casein micelles in milk is discussed and after that the influence of the different processing steps and conditions. The emphasis in this review will be on the distribution of the caseins, calcium and phosphate between the serum and micellar phases, the size and voluminosity of the casein micelle and the influence on viscosity of milk. For a review of other properties see for instance Dalgleish (1997), De Kruif (1999), Holt and Horne (1996), Rollema (1992), Swaisgood (1992) and Walstra (1990).

\subsection{Casein micelles in milk}

In milk about $2.6 \%$ casein is present. The molar ratio of the main fractions $\alpha_{\mathrm{s} 1^{-},}, \alpha_{\mathrm{s} 2^{-}}, \beta-$ and $\kappa$-casein is about 4:1:4:1.6. Caseins have a fairly high negative charge around the $\mathrm{pH}$ of milk. They are fairly hydrophobic molecules, $\beta$-casein being the most hydrophobic one. $\alpha_{s^{-}}$and $\beta$ casein contain clusters of serinephosphate, which can strongly bind calcium. $\kappa$-casein contains two cysteine residues that may form inter and intramolecular disulfide bonds.

Very little casein in uncooled milk is in monomeric form. Most occurs in colloidal aggregates called casein micelles. At room temperature about $5-10 \%$ of casein is not present in casein micelles (Dalgleish and Law, 1988; Davies and Law, 1983; Downey and Murphy, 1970). Davies and Law (1983) studied the distribution of the caseins between the serum and micellar phases in skim milk at $20^{\circ} \mathrm{C}$. They observed that the caseins in the serum phase differed appreciably in composition from the micellar caseins, being rich in $\beta$-casein and 
comparatively poor in $\alpha_{s 1}$ - and $\alpha_{s 2}$-caseins. Similar results were found by Dalgleish and Law (1988).

Besides proteins there are also water (about $3 \mathrm{~g}$ per $\mathrm{g}$ casein), enzymes and salts (about $0.07 \mathrm{~g}$ per $\mathrm{g}$ casein) present in the casein micelles. Milk contains among others the cations of calcium (117 mg/100 g), magnesium (11 mg/100 g), sodium (48 mg/ $100 \mathrm{~g})$ and potassium $(143 \mathrm{mg} / 100 \mathrm{~g})$, and the anions of chloride $(110 \mathrm{mg} / 100 \mathrm{~g})$, phosphorus $(100 \mathrm{mg} / 100 \mathrm{~g})$ and citrate $(175 \mathrm{mg} / 100 \mathrm{~g}$ ) (Walstra et al., 1999). The total concentrations of calcium and inorganic phosphorus in milk are in excess of the solubilities of calcium phosphates. Part of the calcium and phosphate is present as an undissolved salt mixture in the casein micelle. This is usually called colloidal calcium phosphate (CCP). Besides calcium and phosphate also small amounts of magnesium and citrate and presumably other ions are present in CCP. CCP is an essential element in the structure of casein micelles; depletion of CCP leads to dissociation of caseins. Apparently, CCP fulfils a cross-linking function. However, controversy exists concerning the state in which $\mathrm{CCP}$ is present in the micelles. In addition to $\mathrm{CCP}$ the micelles contain counterions of the negatively charged casein. There is a dynamic equilibrium between the salts in the micelles and in the serum. The distribution of calcium, phosphorus, magnesium and citrate over the serum and micellar phase is shown in table 3.1.

Table 3.1. Approximate distribution of phosphorus, calcium and magnesium in milk (percentage of total) (Walstra et al., 1999)

\begin{tabular}{lllll}
\hline & Phosphorus & Calcium & Magnesium & Citrate \\
\hline 1. Casein micelle & & & & \\
CCP & 32 & 54 & 34 & \\
Counterions & & 14 & & 92 \\
Esterified to proteins & 22 & & 66 & \\
2. Serum & & 32 & & \\
$\quad$ Inorganic dissolved & 36 & & & \\
In the phospholipids & 1 & & & \\
Soluble esters & 9 & &
\end{tabular}

Electron microscopy has shown casein micelles to be roughly spherical, ranging from 50-300 $\mathrm{nm}$ in diameter, with a volume/surface average diameter of $80-100 \mathrm{~nm}$. On the micrographs it can be seen that the micelles are build up of small subunits. Some, however, argue that these submicelles are artefacts.

Methods based on hydrodynamic radius (e.g. intrinsic viscosity, diffusion coefficient) yield a value for the voluminosity of casein micelles $\phi$ of roughly $3.9 \mathrm{ml} / \mathrm{g}$ dry casein. Other methods (microscopy, sediment volume) indicate that the voluminosity is about $2.2 \mathrm{ml} / \mathrm{g}$. Roughly half of the discrepancy can be explained by the micelles not being perfect spherical. To explain the remaining difference, it is assumed that the micelles are hairy (Walstra, 1979). 
The hydrodynamic thickness of the hairy layer is about $7 \mathrm{~nm}$. These charged hairs provide stability against flocculation of the micelles by steric and by electrostatic repulsion. The apparent zeta potential for micelles is about $-19 \mathrm{mV}$ at $25^{\circ} \mathrm{C}$ (Pearce, 1976).

The structure of the casein micelle is subject of considerable debate. The model of the casein micelle as a roughly spherical, fairly swollen particle, with a sterically stabilizing outer layer is generally accepted. However, the synthesis of the micelles, the existence of submicelles, the way in which the salts are present and the composition of the outer layer are still discussed. At present there are three models which explain the various properties of the micelles best: the modified submicellar model of Walstra (1999), the dual bonding model of Horne (1998) and the internal structure model of Holt (1992). None of the models can, however, explain all properties of the micelles and the truth may be somewhere in between.

The modified sub-micellar model is based on work of many scientists (e.g. Schmidt, 1982; Schmidt and Buchheim, 1970; Van Dijk, 1992; Walstra, 1990, 1999). The main elements of the model are: (1) Casein micelles are roughly spherical; (2) Micelles are built of spherical subunits; (3) CCP is situated in the submicelles which makes them more compact and decreases their net negative charge. Mainly on account of this the submicelles aggregate into micelles; (4) There are two types of submicelles: one primarily consisting of $\alpha_{s}$ - and $\beta$ casein, the other of $\alpha_{s^{-}}$and $\kappa$-casein; (5) Submicelles containing $\kappa$-casein are primarily situated at the outside of the micelle. Hairs of $k$-casein protrude from the surface thereby preventing the submicelles for further aggregation and providing the micelles stability against flocculation. This model is illustrated in figure 3.1 (Walstra, 1999).
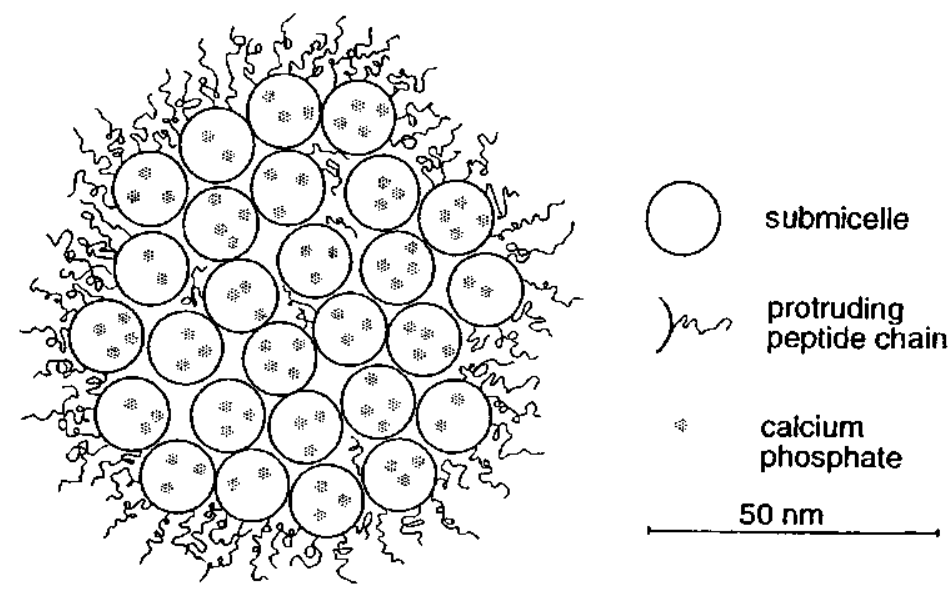

Figure 3.1 Model of a casein micelle according to the sub-micellar model, highly schematic.

The dual bonding model of Horne (1998) assumes that the synthesis and assembly of the casein micelles is governed by a balance of electrostatic repulsion and attractive hydrophobic interactions. In this model $\alpha_{s}$-casein consists of two hydrophobic regions at the 
$\mathrm{N}$ - and $\mathrm{C}$-terminal of the molecule and a hydrophilic region in between. $\beta$ - and $\kappa$-casein consist of a hydrophobic and a hydrophilic region. Hydrophilic regions of $\alpha_{s^{-}}$and $\beta$-casein contain phosphoserine clusters which can be linked by CCP. Two or more hydrophobic regions from different molecules form a bonded cluster. Growth of these polymers is inhibited by the protein charged residues the repulsion of which pushes up the interaction free energy. Neutralisation of phosphoserine clusters by incorporation into the CCP diminishes the free energy as well as producing the second type of crosslinking bridge. Since $\mathrm{K}$-casein has only one hydrophobic region and cannot link with $\mathrm{CCP}$, it acts as a terminator for both types of growth and will become part of the surface structure of the micelle. In contrast to the model described above, in this model not two types of discrete submicelles are present, but protein dense regions of various composition.

The model of Holt (1992) regards the casein micelle as an fairly open structure of protein chains crosslinked by colloidal calcium phosphate nanociusters. In contrast to the two models described above, this model suggests that the outside of the micelle is qualitatively no different in structure from the core. In this model also no submicelles are present.

\subsection{Heat treatment}

Changes caused by heat treatment may be reversible or irreversible. Since only irreversible or slowly reversible changes caused by heating may affect the behaviour of casein micelles in ice cream, these changes are mainly discussed in this chapter. Since ice cream mix is usually pasteurised, the focus here will be on mild heat treatments.

Above $70^{\circ} \mathrm{C}$ most of the serum proteins denature and aggregate. In the serum phase of milk serum protein aggregates and/or serum protein-casein complexes of various size and voluminosity can be formed. Denatured serum proteins can also associate with casein micelles. It is thought that a disulfide interaction with $\kappa$-casein plays an important role hereby and this might affect the properties of the hairy layer. The denaturation of the most important serum proteins $\beta$-lactoglobuline and $\alpha$-lactalbumine has been extensively studied (e.g. Dannenberg and Kessler, 1988a, b; Hillier and Lyster, 1979). The heat-induced proteinprotein interactions are also studied (e.g. Corredig, 1996; Oldfield et al., 1998a, b; Visser et al., 1986), but are not yet fully elucidated and understood. From the literature it is clear that the distribution of denatured serum proteins depends on various conditions during heating (heating time and temperature, and especially $\mathrm{pH}$ ). This distribution affects the properties of milk and milk products (e.g. yoghurt texture, rheological properties of milk gels). Heating of skim milk to such a degree that most of the serum protein is heat denatured causes an increase in its viscosity by about $10 \%$. This is a result of the increase in voluminosity of the serum proteins. Heat treated milk is more shear rate thinning than is unheated milk. The apparent 
diameter of the micelles increases slightly, on average by $2.6 \%$ (Jeurnink 1992; Jeurnink and De Kruif, 1993).

Heat treatment has an effect on the partition of caseins. The intensity of heat treatment plays an important role. Singh et al. (1996) observed that heating milk at physiological pH for 5 min at $70^{\circ} \mathrm{C}$ had no effect, but at $90^{\circ} \mathrm{C}$ it resulted in a small decrease of serum casein after cooling. Law (1996) observed that after heating milk for $10 \mathrm{~min}$ at $85^{\circ} \mathrm{C}$ the amount of serum casein increased from 8.0 to $12.6 \%$, especially the $\mathrm{k}$-casein content increased. The way in which $\mathrm{k}$-casein was present in the serum was not investigated in this study, but from other studies it can be concluded that it might be in the form of $\kappa$-casein/serum protein complexes, small casein aggregates or possibly casein molecules. Heating at temperatures above $90^{\circ} \mathrm{C}$ causes some complex rearrangement of casein components through a series of aggregation and dissociation reactions. The aggregation may eventually lead to coagulation. An overview of the heat coagulation of (concentrated) milk is given, for instance, by Singh et al. (1995).

During heating some calcium and phosphate are transferred from solution to the colloidal state. These changes are for the largest part reversible on cooling, albeit it slowly (Hilgeman and Jenness, 1951, Pouliot, 1989b).

\subsection{Cooling}

The effect of cooling on the behaviour of casein micelles in milk is known to some extent. A number of studies have shown that the amount of casein present in the serum phase increases when the temperature of the milk is reduced. It was found that at $30^{\circ} \mathrm{C}$ about $5 \%$ of the casein was in the serum phase and that this increased to $12-42 \%$ if the milk was cooled to $5^{\circ} \mathrm{C}$ (Ali et al., 1980; Creamer et al., 1977; Dalgleish and Law, 1988; Davies and Law, 1983; Downey and Murphy, 1970; Rose, 1968; Sharma and Randolph, 1974). In most studies it was found that $\beta$-casein is predominantly liberated. The main reason for the dissolution of $\beta$-casein is, presumably, that hydrophobic bonds, by which $\beta$-casein is primarily held in the submicelles, are weaker at low temperatures. This implies that other caseins can also go into solution or be loosened, but less so, and the $\alpha_{\mathrm{s}}$-caseins least (Walstra et al., 1999). Davies and Law (1983) observed that the changes in the composition and distribution of micellar and serum caseins induced by cooling milk at $4^{\circ} \mathrm{C}$ were completely reversible when the milk was re-equilibrated at $20^{\circ} \mathrm{C}$ for $18 \mathrm{~h}$.

Several studies have shown that cold storage of milk causes small amounts of calcium and inorganic phosphorus to dissociate from the casein micelles (Ali et al., 1980; Chen and Yamauchi, 1969; Davies and White, 1960; Pouliot et al., 1989a; Qvist, 1979; Wiechen and Knoop, 1978). Ali et al. (1980) observed that the calcium and phosphorus concentrations showed cycles of increase and decrease during storage of 7 days at $4^{\circ} \mathrm{C}$. The increase in the concentration of soluble calcium and inorganic phosphorus suggests that part of the colloidal 
calcium phosphate has gone into solution. This is supported by the fact that the $\mathrm{pH}$ values of the ultrafiltrates from milk stored at low temperature are higher than those stored at room temperature (Davies and White, 1960; Qvist, 1990). Davies and White (1960) observed that the cold-induced changes were reversible on heating.

Since colloidal calcium phosphate contains a little citrate and magnesium, it is expected that a small part of citrate and magnesium also dissolves on lowering the temperature. Pouliot (1989a) observed that the amount of magnesium and citrate in the ultrafiltrate from milk indeed increased when the holding temperature of the milk was decreased. Qvist (1979) also observed that the amount of magnesium increased. Davies and White (1960), however, observed a decrease in citrate and magnesium in the serum phase.

Several authors (Dewan et al., 1973; Sood et al., 1976) found that the apparent voluminosity of the micelles increases with decreasing temperatures. Though there are fairly large differences between results, on average the hydrodynamic voluminosity was about 4.0 $\mathrm{ml} / \mathrm{g}$ at $25^{\circ} \mathrm{C}$ and $4.7 \mathrm{ml} / \mathrm{g}$ at $5^{\circ} \mathrm{C}$, a difference by a factor of 1.15 . The increase in voluminosity is ascribed to increased hairiness and a more swollen core of the micelles. This may be due to reduced hydrophobic interactions and some dissolution of CCP, resulting in especially $\beta$-casein being less tightly bound.

Despite the increase in voluminosity, the average size of casein micelles decreases somewhat. Schmidt et al. (1974) observed that the numbers of small micelles and of free submicelles increase considerably at the expense of the number of micelles with a diameter of $40 \mathrm{~nm}$ and higher. This may be explained by the assumption that the casein that dissociates from the micelles dissociates not only as free molecules but also in small (sub)micelles. Ali et al. (1980) also found that there was a change in micelle size distribution with storage over a period of $48 \mathrm{~h}$ at $4^{\circ} \mathrm{C}$. However, they found a decrease in the number of smaller micelles (120 nm or less).

The minimum temperature applied in the aforementioned studies is around $3^{\circ} \mathrm{C}$. No research has been done to study the influence, at the same concentration factor, of a further decrease in temperature on properties of the micelle.

\subsection{Concentrating}

Concentrating milk causes numerous changes in properties. The changes depend on the concentration factor $R$ (ratio of dry matter content of the concentrated product to that in the original material) or the increase of the concentration of a substance relative to the amount of water $R^{*}$ and on the method of concentrating. In this chapter concentration methods by which only water is removed, are considered. Most research on concentrated milk has been done on evaporated milk or on frozen milk. However, evaporated milk is usually also heat treated and freezing implies that the temperature is greatly reduced. In this section it is tried to consider 
only the changes caused by concentrating. There is, however, not much literature available on this subject.

Nieuwenhuijse et al. (1991) studied association and dissociation of proteins in concentrated skim milk. The percentages of the different caseins present in the serum phase of not-preheated, not-sterilized concentrated milk hardly showed any difference from those in milk.

As a result of concentrating the salt equilibria change. The concentration of salts increases and therefore their activities. The increase is, however, not proportional to $R^{*}$ since the activity coefficients decrease due to an increase in ionic strength. Milk serum is already saturated with respect to calcium phosphate and an increase in activity as a result of concentration will therefore lead to association of calcium phosphate with the micelles (Nieuwenhuijse et al., 1988; Pouliot and Boulet, 1995). Because of the liberation of $\mathrm{H}^{+}$in calcium phosphate formation and an increase in $\mathrm{H}^{+}$activity due to concentration, the $\mathrm{pH}$ decreases. The $\mathrm{pH}$ decreases by about 0.3 and 0.5 unit for $R=2$ and $R=3$ respectively (Walstra et al., 1999).

The influence on the voluminosity of the micelles is not known. It can be postulated that the increase in $\mathrm{CCP}$ would make the micelles more compact, hence decrease the voluminosity.

According to Walstra et al. (1999) the casein micelles may increase in size as a result of concentrating. This is primarily caused by coalescence of micelles and not by swelling. The increase in size is less if the milk has been preheated to such an extent that most of the serum proteins have become associated with the casein. However, no other references could be found in literature to support this hypothesis.

\subsection{Addition of sucrose}

The addition of sucrose may influence the properties of casein micelles by changing the the solvent quality. No literature is known to us which studies the influence of sucrose on casein and salt distribution over the micellar and serum phase. Famelart (1994) studied the influence of replacement of water by sucrose on the calcium distribution over the serum and micellar phase. However she increased the concentration factor relative to water $R^{*}$ and the effects measured may have been due to concentration as well as to a specific effect of sucrose.

Geerts et al. (1983) observed that the addition of sucrose causes a considerable increase of the $\mathrm{Ca}^{2+}$ activity of skimmed milk and $\mathrm{Ca}^{2+}$-containing aqueous solutions. The increase was found to be proportioned to the amount of sucrose added. To explain the increase several possibilities (water activity, dielectric constant) were examined, but a satisfactory solution could not be found. 
Dewan et al. (1973) observed that addition of $10 \%$ sucrose to skim milk reduced the voluminosity of micelles by about $20 \%$ while further sucrose addition had little influence. From the voluminosity data they calculated a $7 \%$ reduction of hydrodynamic diameter between 0 and $10 \%$ sucrose and nothing beyond. Famelart (1994), however, found an increase in micelle size and a broadening of the size distribution at a concentration of $30 \%$ sucrose.

\subsection{Addition of polysaccharides}

In many milk products stabilizers are added. According to the type of stabilizer and the environmental conditions various types of interactions between proteins and stabilizers can occur in milk. For most casein-stabilizer systems polymer adsorption and depletion phenomena are important. This can result, for instance, in bridging or in depletion flocculation, which may lead to serum separation. Another possibility is that the viscosity of the system is increased (Syrbe et al., 1998).

\subsection{Acidification}

Acidification has a large effect on various properties of the micelles. A decrease in $\mathrm{pH}$ results in dissociation of a portion of all caseins from the micelles. At room temperature the concentration of dissociated casein increases to a maximum of about $7-30 \%$ at around $\mathrm{pH} 5.4$ and then decreases as $\mathrm{pH} 4.6$, the isoelectric point of casein, is approached (Dalgleish and Law, 1988; Singh et al., 1996). Other conditions, like temperature and preheating, affect the $\mathrm{pH}$ induced dissociation of casein. Compared with unheated milk the amount of serum caseins in pre-heated milk acidified at room temperature decreases at all $\mathrm{pH}$ conditions. The $\mathrm{pH}$ of maximum dissociation has a higher value (Law, 1996; Singh et al., 1996). A decrease in temperature of acidification from 20 to $4^{\circ} \mathrm{C}$ leads to an increase in dissociation of caseins at all $\mathrm{pH}$ values (Daigleish and Law, 1988).

When milk is acidified CCP dissociates from the micelles. At pH 5 and below nearly all of the calcium and inorganic phosphorus is present in the serum (Dalgleish and Law; 1989; Law, 1996; Singh et al., 1996; Van Hooydonk et al., 1986). Pre-heating and temperature have no influence on $\mathrm{pH}$ induced dissociation of CCP (Dalgleish and Law 1989; Singh et al., 1996).

The voluminosity of the casein micelle depends strongly on the $\mathrm{pH}$. The maximum voluminosity is around $\mathrm{pH} 5.4$ (Snoeren et al., 1984). The bonds keeping the micelles together are weakest or fewest at this $\mathrm{pH}$.

The average particle size changes little when the $\mathrm{pH}$ is decreased (Roefs et al., 1985). However, as can be concluded from the changes described above, the bonds keeping the 
casein micelles together and the composition of the micelles is different at the various $\mathrm{pH}$ values. The particles will therefore be quite different.

As the isoelectric $\mathrm{pH}$ is approached, the degree of dissociation of the carboxylic groups at the hairs of $\kappa$-casein is diminished. Therefore the solvency of the $\kappa$-casein hairs decreases and the hairy layer collapses. Near the isoelectric $\mathrm{pH}$ the micelles aggregate. Aggregation mostly leads to formation of a precipitate or, more often, of a gel. Several conditions affect the structure of these gels, e.g. preheating the milk (Cobos et al., 1995; Heertje et al., 1985; Kim and Kinsella, 1989; Lucey et al., 1997; Van Vliet and Keetels, 1995), $\mathrm{Ca}^{2+}$ activity (Johnston and Murphy, 1992; Kim and Kinsella, 1989) and concentration of casein micelles (Cobos et al., 1995).

\subsection{Casein micelles in ice cream}

As mentioned in section 2.2.2 the two main functions of casein are probably: acting as an emulsifier during homogenization and as a foaming agent during the freezing and aeration process. It will also contribute to the viscosity of the plasma phase.

Casein micelles are situated at three places in ice cream: in the plasma phase, at the air-plasma and at the fat-plasma interface. The behaviour of casein micelles at these interfaces has been studied to some extent (e.g. Barford et al., 1991; Berger et al., 1972; Berger and White, 1976a,b; Buchheim and Dejmek, 1990; Gelin et al., 1994; Goff et al., 1987). Most of these studies examine the composition of the fat-plasma interface. In general it was concluded that casein is present at the interface, but that in the presence of small molecule emulsifiers the amount decreases during ageing. On electron micrographs of ice cream or ice cream mix casein (sub)micelles could be observed on fat-plasma interface.

Goff et al. (1987) observed that in ice cream mix containing Tween 80 after ageing $7.8 \%$ of protein was adsorbed on the fat-plasma interface. Barford et al. (1991) found that in the presence of small molecule emulsifiers after ageing $8-14 \%$ of the protein was present at the interface and $0-9 \%$ after production of ice cream. Gelin et al. (1994) observed that after homogenization $29 \%$ of the protein was present in the plasma phase, after ageing $34 \%$ and in thawed ice cream $45 \%$. Although there is a large discrepancy between these data, it can, however, be concluded that ice cream plasma contains a large proportion of the casein.

So far, very little research has been done on the behaviour of casein micelles in the plasma phase of ice cream. An attempt was made by Berger and White (1979) to study the casein micelles size distribution in replicas of freeze-etched ice cream. They sized 400 casein micelles and calculated a mean diameter $d_{\mathrm{vs}}$ of $120 \mathrm{~nm}$. They concluded that this corresponds closely to the mean size of about $135 \mathrm{~nm}$ found by Carroll et al. (1968) in milk. Compared to the results of Schmidt et al. (1973), Carroll et al. (1968) observed, however, a larger average diameter. Schmidt et al. (1973) suggested that the larger diameter obtained by Carroll et al. 
(1968) would have been due to underestimation of small particles due to the methods used. It is not sure whether or not Berger and White (1979) did count the submicelles. Therefore and since the conditions of Berger and White (1979) may have been different from ours (e.g. preheat treatment, storage temperature), it is hard to draw definite conclusions from these data. No information is available on other properties of the casein micelle like voluminosity and distribution of the salts over serum and micellar phase.

The conditions in ice cream plasma are extreme: very high ionic strength, considerable supersaturation of several salts, very high sugar concentration, low temperature, etc. Compared with skim milk the concentration factor $R^{*}$ for casein and salts is in our ice cream plasma at $-10^{\circ} \mathrm{C}$ about 7 and the sucrose concentration is $38.4 \%$ (see section 4.2 .1 ). If we consider ice cream plasma to be as a sweetened concentrated skim milk at low temperature, we may try to predict several properties of the casein micelles in ice cream plasma using the knowledge summarised in the aforementioned sections. In table 3.2 it is tried to predict several properties of casein micelles in ice cream plasma based on the influence of concentration and decrease in temperature on properties of casein micelles in milk. In many cases the size of the effect is hard to predict due to differences in these conditions used in literature and our system. For instance in literature the temperature is usually decreased to $+3^{\circ} \mathrm{C}$, and no data for $-18^{\circ} \mathrm{C}$ are available. However, from table 3.2 it is clear that the properties of casein micelles shown in this table would be affected in opposite direction by the two main variables and it is very hard to forecast the net effect. It will even become more complicated if other conditions (e.g. a specific effect of sucrose, a low $\mathrm{pH}$ like in frozen yoghurt, addition of polysaccharides) or an extra processing step (preheating) are taken into account. It was therefore concluded that it is not possible to predict the behaviour of casein micelles in ice cream plasma. Hence experimental work had to be done.

Table 3.2 Estimation of the effects of temperature and solids content on properties of casein micelles in ice cream plasma (+ increase, - decrease)

\begin{tabular}{llll} 
& CCP & Voluminosity & Size \\
\hline Concentration & + & - & + \\
Decrease in temperature & - & + & - \\
\hline Total & $?$ & $?$ & $?$ \\
\hline
\end{tabular}

\section{References}

Ali, A.E., Andrews, A.T. and Cheeseman, G.C. (1980). Influence of storage on casein distribution between the micellar and soluble phases and its relation to cheese-making parameters. Journal of Dairy Research 47, 371.382 
Barford, N.M., Krog, N., Larsen, G. and Buchheim, W. (1991) Effects of emulsifiers on protein-fat interaction in ice cream mix during ageing. 1. Quantitative Analyses. Fat Science Technology 1, 24-35.

Berger, K.G., Bullimore, B.K., White, G.W. and Wright, W.B. (1972) The structure of ice cream. Part 1. Dainy Industries, 419-425.

Berger, K.G. and White, G.W. (1976a) The fat globule membrane in ice cream. Part 1. Definitions, protein components, water and the role of ions. Dairy Industries International. 199-212.

Berger, K.G. and White, G.W. (1976b) The fat globule membrane in ice cream. Part 2. Emulsifiers and highmelting triglycerides. The mosaic model of the membrane. Dairy Industries International, 236-243.

Berger, K.G. and White, G.W. (1979) Ice cream. In Food microscopy, ed. J.G. Vaughan. Academic Press. London, pp. 499-530.

Buchheim, W. and Dejmek, P. (1990) Milk and dairy-type emulsions. In Food Emulsions, eds. K. Larsson and S.E. Friberg. Marcel Dekker Inc., New York, second edition.

Carroll, R.J., Thomson, M.P. and Nutting, G.C. (1968) Glutaraldehyde fixation of casein micelles for electron microscopy. Journal of Dairy Science 51, 1903-1908.

Chen, C. and Yamauchi, K. (1969) Change of salt distribution in milk during frozen storage and its partial reversion after thawing. Agri. Biol. Chem. 33, 1333-1341.

Cobos, A., Horne, D.S. and Muir, D.D. (1995) Rheological properties of acid milk gels. 1. Effect of composition, process and acidification conditions on products from recombined milks. Milchwissenschaft 50, 444-447.

Corredig, M. and Dalgleish, D.G. (1996) Effect of temperature and $\mathrm{pH}$ on the interactions of whey proteins with casein micelles in skim milk. Food Research International 29, 49-55.

Creamer, L.K., Berry G.P. and Mills, O.E. (1977) A study of the dissociation of $\beta$-casein from the bovine casein micelle at low temperature. New Zealand Journal of Dairy Science and Technology 12, 58-66.

Dalgleish, D.G. and Law, A.J.R. (1988) pH-Induced dissociation of bovine casein micelles. 1. Analysis of liberated caseins. Journal of Dairy Research 55, 529-538.

Dalgleish, D.G. (1997) Structure-function relationships of caseins. In Food proteins and their applications, eds S. Damodaran and A. Paraf. Marcel Dekker Inc., New York, pp. 199-223.

Dannenberg, F. and Kessler, H.-G. (1988a) Application of reaction kinetics to the denaturation of whey proteins in milk. Milchwissenschaft 43, 3-7.

Dannenberg, F. and Kessler, H.-G. (1988b) Thermodynamic approach to kinetics of $\beta$-lactoglobulin denaturation in heated skim milk and sweet whey. Milchwissenschaft 43, 139-142.

Davies, D.T. and White, J.C.D. (1960) The use of ultrafiltration and dialysis in isolating the aqueous phase of milk and in determining the partition of milk constituents between the aqueous and disperse phases. Journal of Dairy Research 27, 171-190.

Davies, D.T. and Law, A.J.R. (1983) Variation in the protein composition of bovine casein micelles and serum casein in relation to micellar size and milk temperature. Journal of Dairy Research 50, 67-75.

Dewan, R.K., Bloomfield, V.A., Chudgar, A. and Mor, C.V. (1973) Viscosity and voluminosity of bovine milk casein micelles. Journal of Dairy Science 56, 699-705.

De Knif, C.G. (1999) Casein micelle interactions. International Dairy Journal 9, 183-188. 
Downey, W.K. and Murphey, R.F. (1970) The temperature-dependent dissociation of $\beta$-casein from bovine casein micelles and complexes. Journal of Dairy Research 37, 361-372.

Famelart, M-H. (1994) Rennet coagulation of milk in the presence of sucrose. Journal of Dairy Research 61, 473-483.

Geerts, J.P., Bekhof, J.J. and Scherjan, J.W. (1983) Determination of calcium ion activities in milk with an ionselective electrode. A linear relationship between the logarithm of time and the recovery of the calcium ion activity after heat treatment. Netherlands Milk and Dairy Journal 37, 197-211.

Gelin, J.L., Payen, L., Courthaudon, J.L., Le Meste, M. and Lorient, D. (1994) Structural changes in oil-in-water emulsions during the manufacture of ice cream. Food hydrocolloids 8, 299-308.

Goff, H.D., Liboff, M., Jordan, W.K. and Kinsella, J.E. (1987) The effects of polysorbate 80 on the fat emulsion in ice cream mix: evidence from transmission electron microscopy studies. Food microstructure 6, 193198.

Heertje, I., Visser, J. and Smits, P. (1985) Structure formation in acid milk gels. Food Microstructure 4, 267277.

Hilgeman, M. and Jenness, R. (1951) Observations on the effect of heat treatment upon the dissolved calcium and phosphorus in skimmilk. Journal of Dairy Science 34, 483-484.

Hillier, R.M. and Lyster, R.L.J. (1979) Whey protein denaturation in heated milk and cheese whey. Journal of Dairy Science 46, 95-102.

Holt, C. (1992) Structure and stability of the bovine casein micelle. In Advances in Protein Chemistry, eds. C.B. Anfinsen, J.B. Edsall, F.R. Richards and D.S. Eisenberg. Academic Press, San Diego, pp. 63-151.

Holt, C. and Horne, D.S. (1996) The hairy casein micelle: Evolution of the concept and its implications for dairy technology. Netherlands Milk and Dairy Journal 50, 85-111.

Horne, D.S. (1998) Casein interactions: casting light on the black boxes, the structures in dairy products. International Dairy Journal 8, 171-177.

Jeurnink, Th.J.M. (1992) Changes in milk on heating: turbidity measurements. Netherlands Milk and Dairy Journal, 46, 183-196.

Jeurnink, T.J.M. and de Kruif, K.G. (1993) Changes in milk on heating: viscosity measurements. Journal of Dairy Research 60, 139-150.

Johnston, D.E. and Murphy, R.J. (1992) Effects of some calcium-chelating agents on the physical properties of acid-set milk gels. Journal of Dairy Research 59, 197-208.

Kim, B.Y. and Kinsella, J.E. (1989) Rheological changes during slow acid induced gelation of milk by dglucono- $\delta$-lactone. Journal of Food Science 54, 894-898.

Law, A.J.R. (1996) Effects of heat treatment and acidification on the dissociation of bovine casein mcielles. Journal of Dairy Research 63, 35-48.

Lucey, J.A., Tet Teo, C., Munro, P.A. and Singh, H. (1997) Rheological properties at small (dynamic) and large (yield) deformations of acid gels made from heated milk. Journal of Dairy Research 64, 591-600.

McCrae, C.H. and Muir, D.D. (1985) Heat stability of milk. In Heat-induced changes in milk, ed. P.F. Fox. IDF, Brussels, pp. 206-230. 
Nieuwenhuijse, J.A., Timmermans, W. and Walstra, P. (1988) Calcium and phosphate partitions during the manufacture of sterilized concentrated milk and their relations to the heat stability. Netherlands Milk and Dairy Journal 42, 387-421.

Nieuwenhuijse, J.A., van Boekel, M.A.J.S. and Walstra, P. (1991) On the heat-induced association and dissociation of proteins in concentrated skim milk. Netherlands Milk and Dairy Joumal 45, 3-22.

Oldfield, D.J., Singh, H. and Taylor, M.W. (1998a) Kinetics of denaturation and aggregation of whey proteins in skim milk heated in an ultra-high temperature (UHT) plant. International Dairy Journal 8, 311-318.

Oldfield, D.J., Singh, H. and Taylor, M.W. (1998b) Association of $\beta$-lactoglobuline and $\alpha$-lactalbumine with the casein micelles in skim milk heated in an ultra-high temperature plant. International Dairy Journal 8, 765770 .

Pearce, K.N. (1976) Moving boundary electrophoresis of native and rennet-treated casein micelles. Journal of Dairy Research 43, 27-36.

Pouliot, Y., Boulet, M. and Paquin P. (1989a) An experimental technique for the study of milk salt balance. Journal of Dairy Science 72, 36-40.

Pouliot, Y., Boulet, M. and Paquin, P. (1989b) Observations on the heat-induced salt balance changes in milk II. Reversibility on cooling. Journal of Dairy Research 56, 193-199

Pouliot, Y. and Boulet, M. (1995) Observations on seasonal variations in the saltbalance of concentrated milk. International Dairy Journal 5, 75-85.

Qvist, K.B. (1979) Reestablishment of the original rennetability of milk after cooling. 1. The effect of cooling and LTST pasteurization of milk and renneting. Milchwissenschaft 34, 467-470.

Roefs, S.P.F.M., Walstra, P., Dalgleish, D.C. and Horne, D.S. (1985) Preliminary note on the change in casein micelles caused by acidification. Netherlands Milk and Dairy Journal 39, 119-122.

Rollema, H.S. (1992) Casein association and micelle formation. In Advanced Dairy Chemistry 1: Proteins, ed. P.F. Fox. Elsevier Applied Science, London, pp. 111-140.

Rose, D. (1968) Relation between micellar and serum casein in bovine milk. Journal of Dairy Science 51, 1897. 1902.

Sharma, K.K. and Randolph, H.E. (1974) Influence of mastitis on properties of milk. viii. Distribution of soluble and micellar casein. Journal of Dairy Science 57, 19-23.

Schmidt, D.G. and Buchheim, W. (1970) Elektronenmikroskopische Untersuchung der Feinstruktur von Caseinmicelles in Kuhmilk. Milchwissenschaft 25, 596-600.

Schmidt, D.G., Walstra, P. and Buchheim, W. (1973) The size distribution of casein micelles in cow's milk. Netherlands Milk and Dairy Journal 27, 128-142.

Schmidt, D.G., van der Spek, C.A., Buchheim, W. and Hinz, A. (1974) On the formation of artificial casein micelles. Milchwissenschaft 29, 455-459.

Schmidt, D.G. (1982). Association of caseins and casein micelles structure. In Developments in Dairy Chemistry 1: Proteins, ed. P.F. Fox. Elsevier Applied Science, London, pp. 61-86.

Singh, H. and Creamer, L.K. (1992) Heat stability of milk. InAdvanced Dairy Chemistry - 1: Proteins, ed. P.F. Fox. Elsevier Applied Science, London, pp. 621-656. 
Singh, H. Creamer, L.K. and Nestead, D.F. (1995) Heat stability of concentrated milk. In Heat-induced changes in milk, ed. P.F. Fox. IDF, Brussels, second edition.

Singh, H., Roberts, M.S., Munro, P.A. and Tet Teo, C. (1996) Acid-induced dissociation of casein micelles in milk: Effects of heat treatment. Journal of Dairy Science 79, 1340-1346.

Snoeren, T.H.M., Klok, H.J., Van Hooydonk, A.C.M. and Damman, A.J. (1984) The voluminosity of casein micelles. Milchwissenschaft 39, 461-463.

Sood, S.M., Sidhu K.S. and Dewan, R.K. (1976) Voluminosity of bovine and casein micelles at different temperatures. Milchwissenschaft 31, 470-474.

Syrbe, A., Bauer, W.J. and Klostermeyer, H. (1998) Polymer science concepts in dairy systems - An overview of milk protein and food hydrocolloid interaction. International Dairy Journal 8, 179-194.

Swaisgood, H.E. (1992) Chemistry of the caseins. In Advanced Dainy Chemistry 1: Proteins, ed. P.F. Fox. Elsevier Applied Science, London, pp. 63-110.

Van Dijk, H.J.M. (1992) The properties of casein micelles. 6. Behaviour above $\mathrm{pH} 9$, and implications for the micelle model. Netherlands Milk and Dairy Journal 46, 101-113.

Van Hooydonk, A.C.M., Boerrigter, J.J. and Hagedoorn, H.G. (1986) pH-induced physico-chemical changes of casein micelles in milk and their effect on renneting of milk. 2. Effect of $\mathrm{pH}$ on renneting of milk. Netherlands Milk and Dairy Journal 40, 297-313.

Van Vliet, T. and Keetels, C.J.A.M. (1995). Effect of preheating of milk on structure of acidified milk gels. Netherlands Milk and Dairy Journal 49, 27-35.

Visser, J., Minihan, A., Smits, P., Tjan, S.B. and Heertje, I. (1986) Effects of $\mathrm{pH}$ and temperature on the milk salt system. Netherlands Milk and Dairy Journal 40, 351-368.

Walstra, P. (1979) The voluminosity of bovine casein micelles and some of its implications. Journal of Dairy Research 46, 317-323.

Walstra, P. (1990) On the stability of casein micelles. Journal of Dairy Science 73, 1965-1979.

Walstra, P. (1999) Casein Sub-micelles: Do they exist? International Dairy Journal 9, 189-192.

Walstra, P., Geurts, T.J., Noomen, A., Jellema, A. and Van Boekel, M.A.J.S. (1999) Dairy Technology. Principles of milk properties and processes. Marcel Dekker Inc., New York.

Wiechen, A. and Knoop, A.M. (1978) Investigations on Ca distribution between serum and casein by means of the radioisotope $\mathrm{Ca} 45$ in low cooled and pasteurized milk. Milchwissenschafi 33, 213-215. 


\title{
4
}

\section{Behaviour of casein micelles at conditions comparable to those in ice cream made from low heat milk}

An abridged version of this chapter has been published by M.J. Jonkman, P. Walstra, M.A.J.S. van Boekel and D.J. Cebula in International Dairy Journal, 9, 201-205, 1999.

\begin{abstract}
The structure and stability of the casein micelle are fairly well known under conditions as in milk. However, much less is known and understood for conditions as are prevalent in ice cream. In this study it was observed that structure and behaviour of casein micelles in ice cream plasma at $-10^{\circ} \mathrm{C}$ did not differ greatly from casein micelles in milk. A slightly increased amount of salts was associated with the micelles in ice cream plasma. Electron microscopy showed that casein in ice cream plasma exists in the form of micelles and submicelles. However, compared to milk, fewer submicelles and small micelles were present. Since the voluminosity was about the same as in milk, it was concluded that the increase in micelle size was primarily caused by fusion of micelles and not by swelling. The properties of the casein micelles in ice cream plasma could be explained by a combination of the two conditions which differ significantly from those in milk: high concentration of milk components and low temperature.
\end{abstract}




\subsection{Introduction}

From a physical point of view, ice cream is a complicated disperse system. It is a solid foam of air cells, held together partly by emulsified fat, and partly by a network of small ice crystals dispersed in a concentrated solution of sucrose, skim milk solids and hydrocolloids. This solution (in this study called ice cream plasma) is mostly derived from milk and thus contains casein micelles, or fragments thereof. The casein micelle is an intricate particle, made up of various proteins (caseins), minerals and water. One part of the minerals in the casein micelles is an undissolved salt mixture, usually called colloidal calcium phosphate (CCP). Besides calcium and phosphate also citrate and magnesium are present in CCP. The other part of the minerals in the casein micelles consists of cations (notably $\mathrm{Ca}^{2+}$ and $\mathrm{Mg}^{2+}$ ) that are bound, or present as counterions, to the casein. There is a dynamic equilibrium between the salts in the micelles and the serum.

The structure and stability of the casein micelle are fairly well known under conditions as in milk and several milk products (e.g. Holt and Horne, 1996; Walstra and Jenness, 1984; Walstra, 1990). However, in ice cream it is hardly known. It is known that casein micelles in ice cream are in three locations: at the fat-plasma interface, at the air-plasma interface and in the plasma phase. The behaviour of casein micelles at these interfaces has been studied to some extent (e.g. Barford et al., 1991; Berger et al., 1972; Berger and White, 1976a,b; Buchheim and Dejmek, 1990; Gelin et al., 1994; Goff et al., 1987). So far, very little research has been done on the behaviour of casein micelles in the plasma phase of ice cream. An attempt was made, Berger and White (1979), to study the casein micelles size distribution in replicas of freeze-etched ice cream.

The understanding of the behaviour of casein micelles in milk is insufficient to predict what will happen with the micelles in the plasma phase of ice cream, especially because the conditions in ice cream are so extreme: low temperature, high concentration of milk proteins and salts, high sugar concentration etc. All these variables affect the interaction forces between the components of the micelles, and often in different directions. For instance it is known that at temperatures between 3 and $7{ }^{\circ} \mathrm{C}$ less calcium and phosphate is associated with the micelle than at ambient temperatures (Ali et al., 1980; Chen and Yamauchi, 1969; Davies and White, 1960; Pouliot et al., 1989a,b; Qvist, 1979; Wiechen and Knoop, 1978). Concentration of milk, however, leads to association of calcium phosphate with the micelles (Nieuwenhuijse et al., 1988; Pouliot and Boulet, 1995). It is also known that a decrease in temperature causes a considerable increase in the number of small micelles and of free submicelles (Schmidt et al., 1974). On the other hand, concentration of milk causes an increase in micellar size (Walstra and Jenness, 1984).

From the above, we may conclude that the behaviour of casein micelles in ice cream plasma is hardly known and is hard to predict. However, the behavious of the micelles may well be of importance for the properties (consistency, stability) of ice cream, as it is in many 
other milk products. The objective of this study was to determine and explain the behaviour of casein micelles in a model plasma phase of ice cream.

\section{2 Materials and methods}

\subsubsection{Materials}

The model ice cream plasma was processed in a way that resembles normal ice cream processing as close as possible. The processing scheme was as follows:

1. Mixing of ingredients. Since only the plasma phase was studied, the recipe contained no fat. Stabilizer, emulsifier, flavour and colour substances etc. were deliberately not added, since they could have made the interpretation of the results complicated. The recipe was as follows:

Demineralized water $71.0 \%$

Granulated sugar (CSM Suiker, Amsterdam, the Netherlands)

Skim milk powder, low-heat (Coberco, Lochem, the Netherlands)

Since no fat was added, no homogenization step was applied after mixing.

2. Ageing for 1 night at $+2^{\circ} \mathrm{C}$ to dissolve the skim milk powder.

3. Freezing in a scraped-surface heat exchanger (Schröder Laboratorium-Kombinator VKWK 02/60-400) without aeration. The extrusion temperature was $-5^{\circ} \mathrm{C}$.

4. Packaging in plastic cartons of $250 \mathrm{ml}$.

5. Storage at $-10^{\circ} \mathrm{C}$. This temperature was chosen, since at this temperature still a sufficient amount of plasma and serum (i.e. plasma without casein micelles) could be obtained. The ice cream was stored for at least 2 months to crystallise all lactose that can crystallise at that temperature.

6. Pressing of $250 \mathrm{ml}$ of ice cream wrapped in muslin at 20 bar in a mechanical press (Stadhouders and Mulder, 1957) at $-10^{\circ} \mathrm{C}$ in a freezing chamber to obtain ice cream plasma without most of the ice crystals.

7. Two times centrifugation at $-10^{\circ} \mathrm{C}$ at an average centrifugal force of $13300 \mathrm{~g}$ for 2 hours. As a result all the lactose crystals and the ice crystals that were still present after pressing were removed.

8. Storage at $-10^{\circ} \mathrm{C}$.

The composition of the ice cream plasma was as follows: water $42.28 \%$, sucrose $38.4 \%$, lactose $4.6 \%$, casein $8.39 \%$, whey protein $1.52 \%$, calcium $0.365 \%$, magnesium $0.0343 \%$, phosphorus $0.307 \%$ and citrate $0.70 \%$.

If the samples were equilibrated or analysed at room temperature, $0.01 \%$ thiomersal (BDH Chemicals LTD) was added to the ice cream plasma to prevent bacterial growth. 
Reconstituted skim milk was prepared by dispersing $10.0 \mathrm{~g}$ of low-heat skim milk powder (the same as used for the processing of ice cream plasma) in $90.0 \mathrm{~g}$ demineralized water. To prevent bacterial growth $0.01 \%$ of thiomersal (BDH Chemicals LTD) was added. To allow equilibration, the reconstituted skim milk was stirred for 24 hours at $20^{\circ} \mathrm{C}$.

\subsubsection{Separation of the serum phase}

To determine the fraction of salts present in the casein micelle and in the surrounding serum phase, the plasma had to be fractionated. The serum phase of ice cream plasma and milk was obtained by ultrafiltration. A Gyrosep stirred cell (Intersep, UK) with Nadir regenerated cellúlose $30 \mathrm{kD}$ membranes (Intersep, UK) was used to fractionate ice cream plasma and milk. The maximum pressure difference was 2.5 bar. The first drops of permeate were discarded. The permeate volume never exceeded $5 \%$ of the total volume. Protein was completely retained by the membrane. In the first experiment ice cream plasma was ultrafiltered at $-10^{\circ} \mathrm{C}$. In the second experiment ice cream plasma was ultrafiltered at room temperature. In this experiment ice cream plasma was equilibrated at room temperature for 72 hours before ultrafiltration experiments were performed. In the third experiment ice cream plasma was first equilibrated for 4 days at room temperature, after that for two weeks at $-10^{\circ} \mathrm{C}$ and then ultrafiltered at $-10^{\circ} \mathrm{C}$.

Milk was fractionated at room temperature by ultrafiltration in the same way as described above. To compare the results with other fractionation techniques, milk was also fractionated by ultracentrifugation and by renneting. For fractionation by ultracentrifugation, milk was centrifuged at $70000 \mathrm{~g}$ at $20^{\circ} \mathrm{C}$ during 2 hours in a Beckman XL-90 centrifuge with a S28 rotor. After centrifugation the supernatant was poured off and used for further analysis. For fractionation by renneting $0.025 \%$ of a commercial calf rennet ( $10800 \mathrm{SU}, \mathrm{CSK}$, Leeuwarden, the Netherlands) was added to the reconstituted skim milk at $20^{\circ} \mathrm{C}$. After 5 hours the milk gel was centrifuged at $3330 \mathrm{~g}$ for half an hour. After centrifugation the whey was poured off and used for analysis.

The processing and fractionation of ice cream plasma and milk were conducted at least twice for every type of experiment.

\subsubsection{Chemical analysis}

Total phosphorus content was determined after wet digestion by a colorimetric method according to the International IDF Standard 42B:1990. In the filtrate obtained after precipitation of proteins by addition of trichloroacetic acid (TCA) in a final concentration of $12 \%$ and filtering through S\&S $5951 \frac{1}{2}$ filter paper, the phosphorus content was also estimated. 
Phosphorus in filtrate of TCA minus phosphorus in permeate gives inorganic colloidal phosphate.

Calcium and magnesium were determined after wet digestion by atomic absorption spectrometry at $422.7 \mathrm{~nm}$ and $285.2 \mathrm{~nm}$ respectively using a Perkin-Elmer AA spectrometer model 2380. 0.1\% Lanthanum nitrate hexahydrate (Merck 1.05326) was added to the samples to prevent interference of phosphate in the calcium determination.

Citric acid concentrations were determined using Boehringer Mannheim 139076 test for enzymatic determination.

The standard deviations of the various salt determinations are shown in Table 4.1.

Table 4.1. Reproducibility, expressed as standard deviation $s(\mathrm{mg} / 100 \mathrm{~g})$, for the determination of calcium, magnesium, citrate and phosphorus in ice cream plasma and its permeate and in milk and its permeate, whey and supernatant.

\begin{tabular}{lllll}
\hline & $\mathrm{Ca}$ & $\mathrm{Mg}$ & $\mathrm{Cit}$ & $\mathrm{P}$ \\
\hline Ice cream plasma & 2.9 & 0.17 & 5.3 & 18 \\
Ice cream plasma permeate & 1.1 & 0.25 & 12.2 & 7.6 \\
Milk & 1.5 & 0.45 & 7.1 & 3.9 \\
Milk permeate, whey, supernant & 0.6 & 0.43 & 3.6 & 3.9 \\
\hline
\end{tabular}

The nitrogen content was determined using the macro Kjeldahl method according to IDF Standard 20B:1993. The non-protein nitrogen was determined in the filtrate obtained after precipitation of proteins with $12 \% \mathrm{TCA}$ and filtering through S\&S 5951/2 filter paper. The non-casein nitrogen was determined in the filtrate obtained after precipitation of casein at $\mathrm{pH} 4.6$ with acetic acid and filtering through S\&S 602h filter paper.

Lactose content was determined in the filtrate obtained after precipitation of proteins on addition of perchloric acid (final concentration $0.3 \mathrm{M}$ ) and neutralization with $3 \mathrm{M} \mathrm{KOH}$ to $\mathrm{pH}$ 7. The lactose content was estimated in the filtrate using Boehringer Mannheim 176303 test for the enzymatic determination of lactose and D-galactose.

After precipitation of proteins with Bigg's reagens, the sucrose content was estimated in the filtrate using Boehringer Mannheim 139041 test for enzymatic determination of sucrose/D-glucose.

The amounts of $\mathrm{Ca}, \mathrm{Mg}, \mathrm{P}$, citric acid, $\mathrm{N}$, lactose and sucrose determined in permeates, supernatant, whey and filtrates were recalculated to values in ice cream plasma and milk by applying corrections for non-solvent water and the volume occupied by proteins. The following formula was used (modified after Walstra and Jenness, 1984; van Boekel and Walstra, 1989):

$$
C_{\text {sample }}=C_{\text {permeate }}\{1-[v c+s+h(c+s)]\}
$$




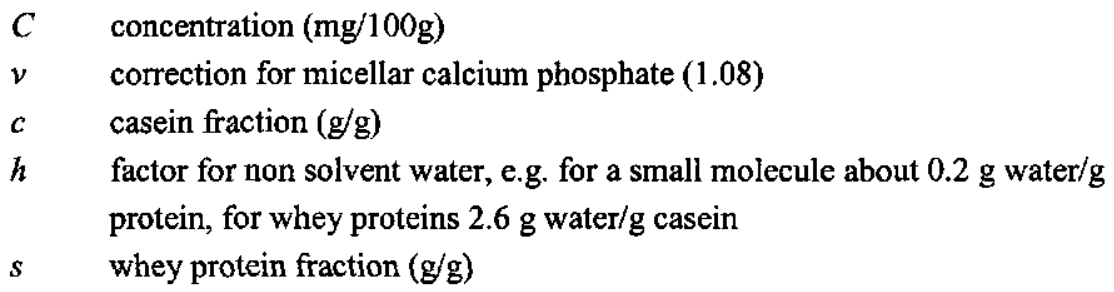

This is a general formula which was applied for every situation in a different way. For instance for permeates casein as well as whey protein fraction have to be taken in account, but for ultracentrifugation only part of the casein fraction.

In most cases, the chemical analyses were performed in triplicate. In tables the mean value is shown.

\subsubsection{Measurement of $\mathrm{pH}$ and calcium ion activity}

Calcium ion activities were determined using an Orion 701A ion meter with an Orion 93-20 calcium selective electrode and an Orion 90-01 single-junction reference electrode filled with $4 \mathrm{M} \mathrm{KCl}$ filling solution (saturated with $\mathrm{AgCl}$ ). The calcium electrode was calibrated with five $\mathrm{CaCl}_{2}$ solutions containing $0.1,0.2,1,2$ or $10 \mathrm{mM} \mathrm{CaCl}_{2}$ and $80 \mathrm{mM} \mathrm{KCl}$. The calcium ion activity was calculated by multiplying the calcium concentration with the activity of $\mathrm{Ca}^{2+}$ $(0.41,0.41,0.40,0.39,0.35$, respectively), as calculated with the Debye-Hückel equation (Walstra and Jenness, 1984). The calcium ion activity was measured under continuous stirring at a constant temperature $\left(28.5^{\circ} \mathrm{C}\right)$ in a water bath. Since the calibration curve changed in the course of measurement time (150 hours), a calibration curve at the start and at the end of a measurement was made. Dependent on the measurement time the calcium ion activities were determined proportional to the start and to the end calibration curve.

The $\mathrm{pH}$ of the samples was measured at room temperature using a Radiometer PHM 62 Standard $\mathrm{pH}$-meter.

\subsubsection{Rheological measurements}

Rheological measurements were performed at $-10^{\circ} \mathrm{C}$ using a Bohlin CVO Rheometer, equipped with concentric cylinders made of stainless steel. The diameter of the inner cylinder was $25 \mathrm{~mm}$, the diameter of the outer cylinder was $27.5 \mathrm{~mm}$.

Two types of measurements were performed. During viscometry the shear stress was varied from $0.02464 \mathrm{~Pa}$ to $11.02 \mathrm{~Pa}$ in 23 steps with equal distance on a logarithmic scale and the corresponding shear rates were measured. Other instrumental settings were: constant delay time $120 \mathrm{~s}$, integration time $60 \mathrm{~s}$. 
Dynamic measurements were also performed. Before the measurements were performed, a preshear at a stress of $300 \mathrm{~Pa}$ was applied for $1800 \mathrm{~s}$ to break up any network present. The instrumental settings during the dynamic measurements were: target strain 0.001 , frequency $0.1 \mathrm{~Hz}$, delay time $10 \mathrm{~s}$, wait time $1200 \mathrm{~s}$. During the dynamic measurements a thin layer of silicone oil was put on the samples to prevent drying out.

\subsubsection{Microscopy}

The appearance of casein micelles in ice cream plasma was observed by freeze-fracture electron microscopy. The samples were kept at $-10^{\circ} \mathrm{C}$ and slammed (block temperature $184^{\circ} \mathrm{C}$ ) using a Reichert MM80E. Samples were then transferred to a Cressington CFE50 freeze-fracture unit and fractured at $-182^{\circ} \mathrm{C}$, followed by unidirectionally shadowing using tantalum/tungsten at an angle of $45^{\circ}$ and backed with rotary carbon at an angle of $90^{\circ}$. All micrographs were taken using a Jeol 1200EXII transmission electron microscope operated at $80 \mathrm{kV}$. Micrographs were taken at X20,000 (microscope magnification) and printed X4 (i.e. $80,000)$.

Casein micelles on the micrographs were sized using General Image Analysis Software.

\subsection{Results and discussion}

\subsubsection{Salt distribution}

As a reference for the salt distribution over the micellar and serum phase in ice cream plasma the salt distribution in milk was estimated. The fractionation of milk was done in three ways: ultrafiltration, renneting and ultracentrifugation. In the permeate, whey and supernatant the percentages of calcium, magnesium, citrate and phosphate were determined and these were used for the calculation of the salts present in the serum phase of milk. The results are shown in Table 4.2. Compared to percentages of salts in the serum phase estimated with renneting and ultracentrifugation (Table 4.2, milks 2 and 3) and to literature values (Table 4.3, milks 2, 3 and 4), the percentages of salts present in the serum phase of milk estimated by ultrafiltration in this study were rather low. Results obtained by ultrafiltration by Pouliot et al. (1989a, 1995) (Table 4.3, milk no 1) were quite similar to the ultrafiltration results obtained in this study. Dalgleish and Law (1989) also found that the amounts of $\mathrm{Ca}$ and $\mathrm{P}$ in permeates of milk were lower than in the supernatants obtained by ultracentrifugation. The difference between the results obtained by ultrafiltration and renneting is probably due to precipitation of calcium phosphate on the surface of and inside the ultrafiltration membrane. Hanemaaijer et 
al. (1989) studied the ultrafiltration of simulated milk ultrafiltrate. They found that salts had precipitated on the surface of, and especially inside the membranes and that these deposits consisted almost exclusively of calcium and phosphate. The precipitation is presumably a result of the enhanced concentration of the salts near and in the membrane. It can also be seen in Table 4.2 that ultracentrifugation in this study yielded higher fractions of salts in the serum phase. Since the sedimentation velocity of submicelles was very low (calculated at about 2 $\mathrm{mm} / \mathrm{h}$ ), it was expected that submicelles and small micelles, including their micellar calcium phosphate and counterions, still would be present in the supernatant. The amount of $\mathrm{N}$ present in the supernatant was about $30 \%$ of the total protein N. Since about $20 \%$ of the protein nitrogen was whey protein nitrogen, about $12.5 \%$ of the casein was apparently present in the supernatant. It was supposed that renneting of milk had not much influence on the calcium phosphate distribution (Schipper, 1961) and that no casein and micellar calcium phosphate was present in the whey. In our opinion renneting would therefore give the most reliable results for the distribution of salts over the micellar and serum phase in milk.

Table 4.2. Percentage of calcium, magnesium, citrate and phosphorus present in the serum phase of reconstituted skim milk at room temperature. The serum phase was obtained by ultrafiltration (no. 1), renneting (no. 2) or ultracentrifugation (no. 3). The correction factors used for non-solvent water and the volume occupied by proteins were for the ultrafiltration experiments 0.962, for the renneting and ultracentrifugation experiments 0.968 . Between brackets the standard deviation is shown.

\begin{tabular}{llll}
\hline Method & 1. uf RC 30 kD & $2.0 .025 \%$ rennet & 3. uc 70 000 g 2 h \\
\hline $\mathrm{Ca}$ & $26.2(0.54)$ & $29.5(0.58)$ & $36.5(0.57)$ \\
\hline $\mathrm{Mg}$ & $58.3(4.4)$ & $65.1(4.3)$ & $71.8(5.5)$ \\
\hline $\mathrm{Cit}$ & $81.7(3.2)$ & $88.0(4.1)$ & $93.2(3.2)$ \\
\hline $\mathrm{P}$ & $40.9(3.9)$ & $47.4(4.4)$ & $56.0(4.4)$ \\
\hline
\end{tabular}


Table 4.3. Percentage of calcium, magnesium, citrate, phosphorus and inorganic phosphorus present in the serum phase of milk at room temperature obtained by various references. $n d=$ not determined.

\begin{tabular}{|c|c|c|c|c|}
\hline $\begin{array}{l}\text { Type of milk } \\
\text { Method } \\
\text { Reference }\end{array}$ & $\begin{array}{l}\text { 1. raw } \\
\text { uf PS } 50 \mathrm{kD} \\
\text { Pouliot et al. } \\
(1989 \mathrm{a}, 1995)\end{array}$ & $\begin{array}{l}\text { 2. raw } \\
\text { renneting } \\
\text { Van Boekel and } \\
\text { Van den Berg, } \\
\text { unpublished results }\end{array}$ & $\begin{array}{l}\text { 3. raw, skimmed } \\
\text { uc } 50000 \mathrm{~g} 1 \mathrm{~h} 30 \mathrm{~min} \\
\text { Law (1996) }\end{array}$ & $\begin{array}{l}\text { 4. skimmed } \\
\text { dialysis } \\
\text { Holt (1985) }\end{array}$ \\
\hline $\mathrm{Ca}$ & 26,24 & 28 & 33 & 33 \\
\hline $\mathrm{Mg}$ & 64,57 & 70 & nd & 63 \\
\hline Cit & 90,71 & nd & nd & 96 \\
\hline $\mathbf{P}$ & nd, nd & 44 & nd & nd \\
\hline$P_{i}$ & 57,50 & 57 & 52 & 56 \\
\hline
\end{tabular}

Although renneting would be the most suitable method for estimating the salt distribution in ice cream plasma, this method was not applied since the activity of chymosin would be very low at $-10^{\circ} \mathrm{C}$ and aggregation of micelles would have taken a very long time or would not occur. Ultracentrifugation was also not possible since the sedimentation velocity of micelles in ice cream plasma at $-10^{\circ} \mathrm{C}$ is very low. Therefore the only possible method for fractionation of the serum phase at $-10^{\circ} \mathrm{C}$ was ultrafiltration. The salt distribution over the serum and the micellar phase in ice cream plasma at $-10^{\circ} \mathrm{C}$ is shown in Table 4.4 (plasma 1 ).

Table 4.4. Percentage of calcium, magnesium, citrate and phosphorus present in the serum phase of ice cream plasma at $-10^{\circ} \mathrm{C}$ and room temperature. The correction factor used for non-solvent water and the volume occupied by proteins was 0.879 . Between brackets the standard deviation is shown.

\begin{tabular}{llll}
\hline & 1. uf at $-10^{\circ} \mathrm{C}$ & 2. uf at room temp & 3. uf at $-10^{\circ} \mathrm{C}$ after equilibration at room temp \\
\hline $\mathrm{Ca}$ & $21.6(0.32)$ & $7.46(0.26)$ & $7.94(0.28)$ \\
\hline $\mathrm{Mg}$ & $52.5(0.72)$ & $45.0(0.67)$ & $41.1(0.73)$ \\
\hline $\mathrm{Cit}$ & $71.3(1.7)$ & $39.3(1.6)$ & $32.2(1.9)$ \\
\hline $\mathrm{P}$ & $37.7(3.2)$ & $34.6(2.9)$ & $41.3(3.4)$ \\
\hline
\end{tabular}

The conditions (temperature, time, concentration) for ultrafiltration of ice cream plasma at $-10^{\circ} \mathrm{C}$ and milk at room temperature were different. Therefore, the percentage of salts precipitated on the surface of and inside the membranes might not be the same and it will not be possible to draw definitive conclusions from the comparison. It can be seen from Table 4.2 (milk 1) and 4.4 (plasma 1) that the percentages of all salts present in the serum phase 
were slightly lower for ice cream plasma. The differences were significant for calcium, magnesium and citrate (students's test, 95\% confidence). As mentioned above, it is known that at refrigeration temperatures less calcium and phosphate is associated with the micelle than at room temperature (Ali et al., 1980; Chen and Yamauchi, 1969; Dalgleish and Law, 1989; Davies and White, 1960; Pouliot, 1989a,b; Qvist, 1979; Wiechen and Knoop, 1978). This is, however, only known for temperatures down to $3^{\circ} \mathrm{C}$. What the influence is of further lowering the temperature on the calcium phosphate distribution is not known. It is also known that concentration leads to association of calcium phosphate with the micelles (Nieuwenhuijse et al., 1988; Pouliot and Boulet, 1995). If the observed lower percentage of salts in the serum phase is not due to the difference in ultrafiltration conditions, it can be concluded that the total effect of concentration and lowering the temperature on the calcium phosphate distribution in ice cream plasma is a slightly enhanced association of calcium phosphate with the micelles. At $-10^{\circ} \mathrm{C}$ the concentration effect then would be slightly stronger than the temperature effect.

For the molar micellar $\mathrm{Ca}: \mathrm{P}_{\text {; }}$ ratio in ice cream plasma stored at $-10^{\circ} \mathrm{C}$ a value of 1.83 and in milk fractionated by ultrafiltration a value of 1.91 was found. This was about the same as the values found for milk by Dalgleish and Law (1989). They observed in milk over a wide range of temperatures and $\mathrm{pH}$ values a ratio of $1.75-1.84 \mathrm{~mol} \mathrm{Ca} / \mathrm{mol} \mathrm{P}$. It can therefore be concluded that the micellar calcium to inorganic phosphate ratio is about the same in milk as in ice cream plasma at $-10^{\circ} \mathrm{C}$.

Table 4.4 (plasma 1 and 2) shows that warming ice cream plasma to room temperature caused a decrease in the percentages of salts present in the serum phase. In particular the percentages of calcium and citrate in the serum phase decreased. An explanation for this phenomenon may be that besides precipitation of calcium phosphate in the micelles also precipitation of calcium citrate would have occurred. In concentrated milk deposits of calcium citrate have been observed (Deysher and Webb, 1952) and calculations by Lyster (1979) showed that formation of tricalcium citrate would be possible under these circumstances in a salt solution similar in ionic composition to an ultrafiltrate of milk. The observation that during storage at $-10^{\circ} \mathrm{C}$ calcium and citrate were not present in such low quantities in the serum phase, could be due to several reasons. The first explanation could be that the solubility product of calcium citrate is higher at lower temperatures. The second explanation could be that due to changes in salt equilibria, ice cream plasma at $-10^{\circ} \mathrm{C}$ is less saturated with respect to calcium citrate. The third explanation is that ice cream plasma is saturated with respect to calcium citrate and that calcium citrate precipitates at $-10^{\circ} \mathrm{C}$, but very slowly. To study this, two type of experiments were performed. In the first experiments ice cream plasma was stored for various times (varying between two and six months) and fractionated. No differences in salt distribution between long and short periods of storage at $-10^{\circ} \mathrm{C}$ could be observed. The third explanation is therefore less likely. In the second experiment ice cream plasma was obtained at $-10^{\circ} \mathrm{C}$, stored for 4 days at room temperature to induce formation of calcium citrate, stored at $-10^{\circ} \mathrm{C}$ for two weeks and fractionated by ultrafiltration. If explanation one or 
two would be right then an increase in calcium and citrate in serum phase would be expected. It can, however, be seen from Table 4.4 (plasma 2,3) that after storage of two weeks at $-10^{\circ} \mathrm{C}$ the percentages of calcium in the serum phase of ice cream plasma fractionated at $-10^{\circ} \mathrm{C}$ did not differ significantly from the plasma fractionated at room temperature. The magnesium content was even slightly decreased. It appears from these results that the third explanation would be right. However, it may also be that due to the poor solubility of the precipitated calcium citrate, the precipitated salts did not dissolve again or very slowly at $-10^{\circ} \mathrm{C}$. The results from experiment 1 are also not in agreement with the results from experiment 2 . Therefore it is not possible to draw definitive conclusions from these experiments.

\section{$4.3 .2 \mathrm{pH}$ and calcium ion activity}

Ice cream plasma samples were warmed up to $28.5^{\circ} \mathrm{C}$ and as soon as this temperature was reached, the calcium ion activity and the $\mathrm{pH}$ in time were recorded (Fig. 4.1).

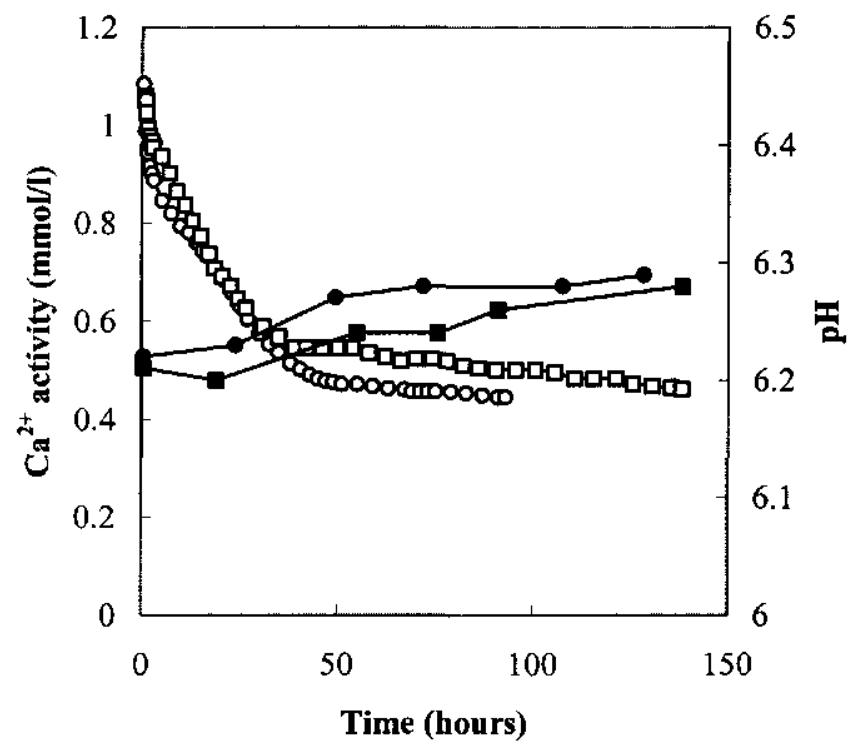

Fig. 4.1. Calcium ion activity $(\mathrm{O}, \square)$ and $\mathrm{pH}(\boldsymbol{\bullet}, \boldsymbol{\square})$ at $28.5^{\circ} \mathrm{C}$ as a function of time after warming up from $-10^{\circ} \mathrm{C}$ to $28.5^{\circ} \mathrm{C}$ of two samples of ice cream plasma (sample $1: 0,0$; sample 2: $\boldsymbol{\boldsymbol { n }}, 7$.

As mentioned above, the conditions in ice cream are extreme: low temperature, high concentration of milk components and sucrose. Since the last two conditions were kept the same, the course in Fig. 4.1 was a result of increasing the temperature. As a result the salt 
equilibria changed and the calcium ion activity markedly decreased and the $\mathrm{pH}$ somewhat increased. It can be seen in Fig. 4.1 that it takes quite a long time to establish equilibrium between the salts in milk after increasing the temperature. The first 40 hours the calcium ion activity decreased very fast, after that it still decreased, but more slowly. The pH changed too, but more gradually. An increase in $\mathrm{pH}$ of about 0.08 was observed. Since the calcium ion activity is a product of activity coefficient as well as the free calcium ion concentration, both might have changed during the time of the measurement. It was shown in Table 4.4 that as a result of increasing the temperature from $-10^{\circ} \mathrm{C}$ to room temperature the total amount of calcium present in the serum phase decreased. In all probability the free calcium ion content in the serum phase might therefore have decreased too. As a result of association of salts with the micelles, the ionic strength might have decreased and the activity coefficient might have increased. Fig. 4.1 shows, however, that this effect could not have been large, since the calcium ion activity decreased during the storage at $28.5^{\circ} \mathrm{C}$. The $\mathrm{pH}$ changed during storage as a result of the association of calcium phosphate with the micelles. However, we did not expect an increase in $\mathrm{pH}$, but rather a decrease, since it is known that $\mathrm{H}^{+}$ions are liberated during heating of milk to pasteurisation/sterilisation temperatures as a result of precipitation of calcium phosphate (Walstra and Jenness, 1984). The association constants of salts may, however, vary with temperature. As suggested in section 4.4.1 other reactions might have taken place and other products might have been formed than the normal ones during heating.

If we assume that changing the temperature of ice cream plasma did not cause irreversible changes in the salt distribution, we may suppose that the final calcium ion activity and $\mathrm{pH}$ was only a result of high concentration of milk components and sucrose. The final calcium ion activity of the plasma at the end of the measurement was very low, $0.45 \mathrm{mmol} / \mathrm{l}$. It was lower than the calcium ion activity of reconstituted skim milk after 24 hours equilibrium, $0.67 \mathrm{mmol} / \mathrm{l}$. It is known that concentration causes a decrease in calcium ion activity at a given $\mathrm{pH}$ (Nieuwenhuijse et al., 1988) and that addition of sucrose to milk causes a considerable increase of the calcium ion activity (Geerts et al., 1983). The fact that the final calcium ion activity was lower than in milk, must be due to the very high concentration factor. In comparison to milk the concentration of casein (and salts) relative to the amount of water was 6 times higher. Concentration of milk leads to a decrease in $\mathrm{pH}$ (Walstra and Jenness, 1984). The $\mathrm{pH}$ of ice cream plasma at room temperature was also lower than of reconstituted skim milk (6.65).

\subsubsection{Rheology}

The viscosity as a function of shear rate was determined for ice cream plasma and its permeate at $-10^{\circ} \mathrm{C}$ (Fig. 4.2). It was observed that ice cream plasma was slightly shear rate 
thinning. The viscosity at a shear rate of $350 \mathrm{~s}^{-1}$ was $0.151 \mathrm{~Pa} . \mathrm{s}$ for permeate $\left(\eta_{\text {serum }}\right)$ and 0.714 Pa.s for ice cream plasma ( $\left.\eta_{\text {plasma }}\right)$.

Snoeren et al. (1982) concluded that the Eilers relation fairly well predicts the viscosity of concentrated skim milks. Their results can be used to estimate the hydrodynamic voluminosity of casein micelles in ice cream plasma. The viscosity of the ice cream plasma $\eta_{\text {plasma }}$ can be expressed as a function of the volume fraction of the protein $\phi$; in ice cream plasma this is the volume fraction occupied by casein $\left(\phi_{c}\right)$, native whey protein $\left(\phi_{n w}\right)$ and denatured whey protein $\left(\phi_{\mathrm{dw}}\right)$. We thus have

$$
\begin{array}{ll}
\eta_{\text {plasma }} & =\eta_{\text {serum }}\left[1+1.25 \phi /\left(1-\phi / \phi_{\text {max }}\right)\right]^{2} \\
\phi & =\phi_{\mathrm{c}}+\phi_{\mathrm{nw}}+\phi_{\mathrm{dw}}
\end{array}
$$

And generally

$$
\phi_{\mathrm{x}} \quad=\nu_{\mathrm{x}} c_{\mathrm{x}}
$$

In ice cream plasma the casein concentration $c_{\mathrm{c}}$ was $0.103 \mathrm{~g} / \mathrm{ml}$. It was assumed that no whey protein was denatured and that the native whey protein concentration was $c_{\mathrm{nw}} 0.0183 \mathrm{~g} / \mathrm{ml}$. Snoeren et al. (1982) took for the maximum volume fraction $\phi_{\max }$ a value of 0.79 and for the voluminosity of native whey protein $v_{\mathrm{nw}} 1.07 \mathrm{ml} / \mathrm{g}$. Substitution of these values in the equations yields a voluminosity of casein micelles in ice cream plasma $v_{c}$ of $4.0 \mathrm{ml} / \mathrm{g}$. Since in milk usually a value of roughly $3.9 \mathrm{ml} / \mathrm{g}$ casein is found (Walstra, 1979) we may conclude that the voluminosity of casein micelles in ice cream plasma at $-10^{\circ} \mathrm{C}$ was about the same as in milk at room temperature.

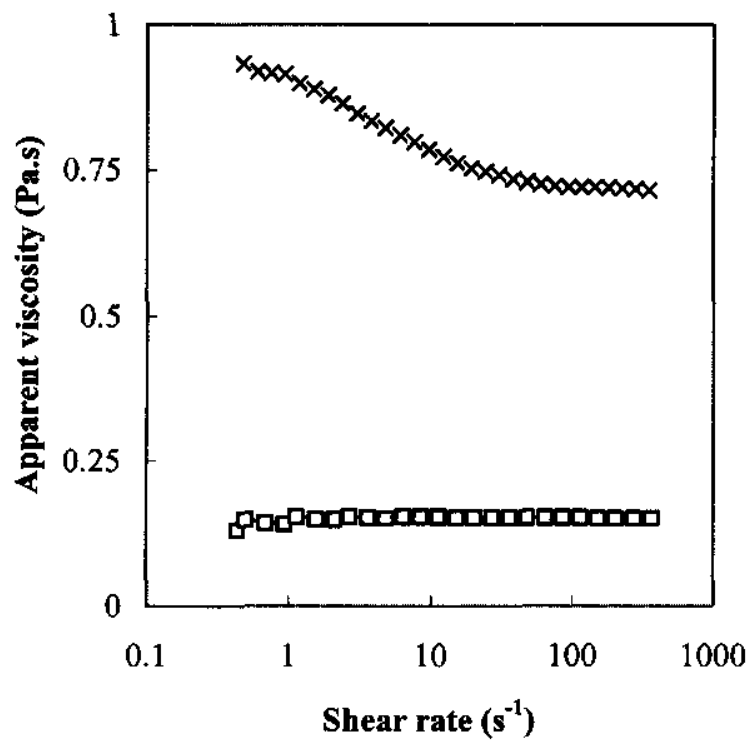

Fig. 4.2. The apparent viscosity of ice cream plasma $(x)$ and the serum phase of ice cream plasma ( $\square$ ) at $-10^{\circ} \mathrm{C}$. The serum phase was obtained by ultrafiltration. 
It is known that decreasing the temperature in milk to $5^{\circ} \mathrm{C}$ leads to a significant increase in voluminosity. The influence of concentration of milk on the voluminosity of casein micelles is not known. Presumably it will lead to a decrease in voluminosity, since additional calcium phosphate is formed which would tend to make the micelles more compact. In our system, the effect of decreasing the temperature appears to neutralize the effect of concentration of milk on the voluminosity.

Oscillation measurements showed no change in moduli in time during $10^{5} \mathrm{~s}$. It might therefore be concluded that network formation did not occur.

\subsubsection{Microscopy}

The appearance of the micelles in ice cream plasma at $-10^{\circ} \mathrm{C}$ is shown in Fig. 4.3. It can be seen that casein exist as micelles and as submicelles. When we compare this micrograph with micrographs of milk, it appeared to us that fewer submicelles were present in ice cream plasma than in milk. No network could be observed on the micrographs.

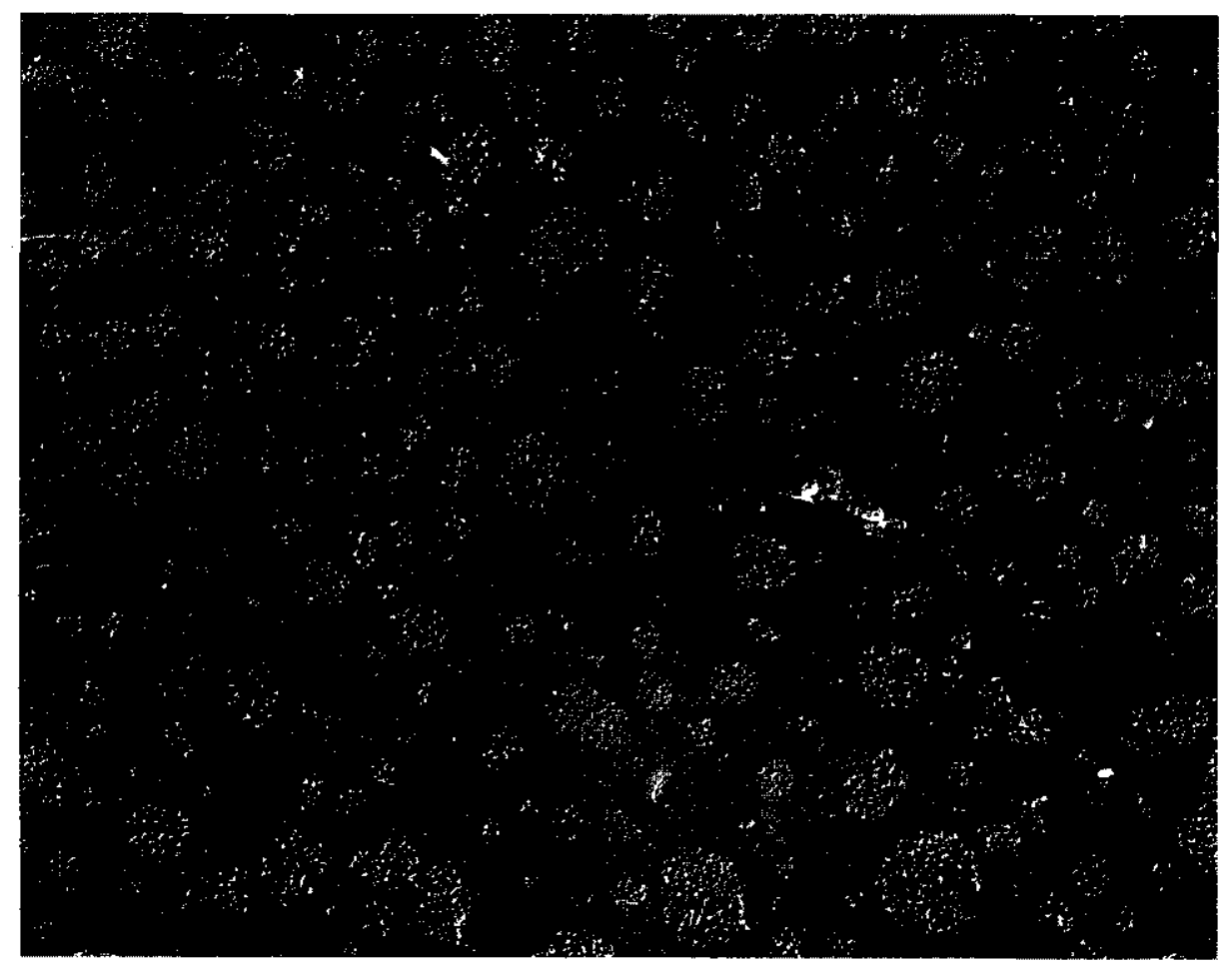

Fig. 4.3. Freeze-fracture electron micrograph (TEM) of casein micelles in ice cream plasma at $-10^{\circ} \mathrm{C}$ (scale bar $=500 \mathrm{~nm}$ ). 
On electron micrographs of ice cream plasma 277 micelles were sized. The number of micelles counted was too low to derive a reliable size distribution. However, size distribution parameters can roughly be estimated from these data (Buchheim et al., 1995). The estimated surface average diameter $d_{v s}$ was $101 \mathrm{~nm}$, the number average diameter $d_{10}$ was $39 \mathrm{~nm}$ and the distribution width $c_{s}$ was 0.60 . Schmidt et al. (1973) also used electron micrographs for sizing of micelles and found for micelles in milk at room temperature a $d_{v s}$ of $86 \mathrm{~nm}, d_{10}$ of $25 \mathrm{~nm}$ and a distribution width $\mathcal{c}_{s}$ of 0.38 . The larger average micelle size in ice cream plasma may be due to fusion of micelles or to swelling. Since the viscosity measurements showed that the voluminosity of casein micelles was in ice cream plasma at $-10^{\circ} \mathrm{C}$ about the same as in milk at room temperature, it can be concluded that the increase in size was primarily caused by fusion of micelles.

It is known that decreasing the temperature of milk to $5^{\circ} \mathrm{C}$ causes a considerable increase in the number of small micelles and submicelles (Schmidt et al., 1974). On the other hand, concentration of milk causes an increase in micellar size (section 5.3.5). Since the average micelle size increased, it appears that the effect of concentration is more important than that of temperature.

Berger and White (1979) studied the casein micelles in replicas of freeze-etched ice cream. They sized 400 casein micelles and calculated a mean diameter $d_{v s}$ of $120 \mathrm{~nm}$. As argued in section 3.8 , it is, however, hard to draw conclusions from the comparison of our data with the data obtained by Berger and White.

\subsection{Conclusions}

The results obtained show that structure and behaviour of the casein micelles in ice cream plasma do not differ greatly from the casein micelles in milk. A slightly higher percentage of salts is associated with the micelles in ice cream plasma. The voluminosity of casein micelles is about the same as in milk. The average size of micelles is increased. Fewer submicelles and small micelles were observed and some fusion of micelles must have occurred. The $\mathrm{pH}$ and calcium ion activity at room temperature are lower than in milk.

Most of the properties of the casein micelles in ice cream plasma may be explained by a combination of the two conditions that differ significantly as compared to milk: high concentration of milk components (and sucrose) and low temperature. The effect of concentration on the micelle properties is slightly stronger than and opposite to the effect of a decrease in temperature. 


\section{Acknowledgements}

The authors thank Mrs J. Brigham (Unilever Research Colworth Laboratory) for making the electron micrographs and Mrs M.A.H. Baltussen (Wageningen University) for performing part of the salt analyses.

\section{References}

Ali, A.E., Andrews, A.T. and Cheeseman, G.C. (1980) Influence of storage of milk on casein distribution between the micellar and soluble phases and its relationship to cheese-making parameters. Journal of Dairy Science 47, 371-382.

Barford, N.M., Krog, N., Larsen, G. and Buchheim, W. (1991) Effects of emulsifiers on protein-fat interaction in ice cream mix during ageing. 1. Quantitative Analyses. Fat Science Technology 1, 24-35.

Berger, K.G., Bullimore, B.K., White, G.W. and Wright, W.B. (1972) The structure of ice cream. Part 1. Dairy Industries, 419-425.

Berger, K.G. and White, G.W. (1976a) The fat globule membrane in ice cream. Part 1. Definitions, protein components, water and the role of ions. Dairy Industries International. 199-212.

Berger, K.G. and White, G.W. (1976b) The fat globule membrane in ice cream. Part 2. Emulsifiers and highmelting triglycerides. The mosaic model of the membrane. Dairy Industries International, 236-243.

Berger, K.G. and White, G.W. (1979) Ice cream. In Food Microscopy, ed. J.G. Vaughan. Academic Press, London, pp.499-530.

Buchheim, W. and Dejmek, P. (1990) Milk and dairy-type emulsions. In Food Emulsions, eds. K. Larsson and S.E. Friberg. Marcel Dekker Inc., New York, second edition, pp. 203-247.

Buchheim, W., Krause, J.-P. and Rathjen, G (1995) An improved procedure for estimating size distribution parameters of spherical and non-spherical particles from their planar cross-sections. Kieler Milchwirtschaftliche Forschungsberichte 47, 177-183.

Chen, C. and Yamauchi, K. (1969) Change of salt distribution in milk during frozen storage and its partial reversal after thawing. Agr. Biol. Chem. 33, 1333-1341.

Dalgleish, D.G. and Law, A.J.R. (1989) pH-induced dissociation of bovine casein micelles. 2. Mineral solubilization and its relation to casein release. Journal of Dairy Research 56, 727-735.

Davies, D.T. and White, J.C.D. (1960) The use of ultrafiltration and dialysis in isolating the aqueous phase of milk and in determining the partition of milk constituents between the aqueous and disperse phase. Journal of Dairy Research 27, 171-190.

Deysher, E.F. and Webb, B.H. (1952). Factors that affect the formation of a crystalline deposit in evaporated milk. Journal of Dairy Science 35, 106-115.

Geerts, J.P., Bekhof, J.J. and Scherjon, J.W. (1983) Determination of calcium ion activities in milk with an ionselective electrode. A linear relationship between the logarithm of time and the recovery of the calcium ion activity after heat treatment. Netherlands Milk and Dairy Journal 37, 197-211. 
Gelin, J.L., Payen, L., Courthaudon, J.L., Le Meste, M. and Lorient, D. (1994) Structural changes in oil-in-water emulsions during the manufacture of ice cream. Food hydrocolloids 8, 299-308.

Goff, H.D., Liboff, M., Jordan, W.K. and Kinsella, J.E. (1987) The effects of polysorbate 80 on the fat emulsion in ice cream mix: evidence from transmission electron microscopy studies. Food microstructure 6, 193 198.

Hanemaaijer, J.H., Robbertsen, T., van den Boomgaard, Th. and Gunnink, J.W. (1989) Fouling of ultrafiltration membranes. The role of protein adsorption and salt precipitation. Journal of Membrane Science 40, 199217.

Holt, C. (1985) The milk salts: their secretion, concentrations and physical chemistry. In Developments in dairy chemistry. 3. Lactose and minor constituents, ed. P.F. Fox. Elsevier Applied Science Publishers, London, pp. 143-181.

Holt, C. and Home, D.S. (1996) The hairy casein micelle: Evolution of the concept and its implications for dairy technology. Netherlands Milk and Dairy Journal 50, 85-111.

Law, A.J.R. (1996) Effects of heat treatment and acidification on the dissociation of bovine casein micelles. Journal of Dairy Research 63, 35-48.

Lyster, R.L.J. (1979) The equilibria of calcium and phosphate ions with the micellar calcium phosphate in cow's milk. Journal of Dairy Research 46, 343-346.

Nieuwenhuijse, J.A., Timmermans, W. and Walstra, P. (1988) Calcium and phosphate partitions during the manufacture of sterilized concentrated milk and their relations to the heat stability. Netherlands Milk and Dairy Journal 42, 387-421.

Pouliot, Y., Boulet, M. and Paquin, P. (1989a) An experimental technique for the study of milk salt balance. Journal of Dairy Science 72, 36-40.

Pouliot, Y., Boulet, M. and Paquin, P. (1989b) Observations on the heat-induced salt balance changes in milk. 1. Effect of heating time between 4 and $90^{\circ} \mathrm{C}$. Journal of Dairy Research 56, 185-192.

Pouliot, Y. and Boulet, M. (1995) Observations on the seasonal variations in the salt balance of concentrated milk. International Dairy Journal 5, 75-85.

Qvist, K.B. (1979) Reestablishment of the original rennetability of milk after cooling. 1. The effect of cooling and ltst pasteurization of milk and renneting. Milchwissenschaft 34, 467-470.

Schipper, C.J. (1961) Het caseinaatphosphaatcomplex van melk. Wageningen Agricultural University, Wageningen, $\mathrm{PhD}$ thesis.

Schmidt, D.G., Walstra, P. and Buchheim, W. (1973) The size distribution of casein micelles in cow's milk. Netherlands Milk and Dairy Journal 27, 128-142.

Schmidt, D.G., Spek, C.A. van der, Buchheim, W. and Hinz, A. (1974) On the formation of artificial casein micelles. Milchwissenschaft 29, 455-459.

Snoeren, T.H.M., Damman, A.J. and Klok, H.J. (1982) The viscosity of skim-milk concentrates. Netherlands Milk and Dairy Journal 36, 305-316.

Stadhouders, J. and Mulder, H. (1957) Fat hydrolysis and cheese flavour. 1. The enzymes responsible for the hydrolysis of fat in cheese. Netherlands Mitk and Dairy Journal 11, 164-183. 
Van Boekel, M.A.J.S. and Walstra, P. (1989) Steric exclusion of serum proteins with respect to (para) casein micelles. Netherlands Milk and Dairy Journal 43, 437-446.

Walstra, P. (1979) The voluminosity of bovine casein micelles and some of its implications. Journal of Dairy Research 46, 317-323.

Walstra, P. and Jenness, R. (1984) Dairy Chemistry and Physics. John Wiley \& Sons, New York.

Walstra, P. (1990) On the stability of casein micelles. Journal of Dairy Science 73, 1965-1979.

Wiechen, A. and Knoop, A.M. (1978) Untersuchungen zur Ca-Verteilung zwischen casein und serum mit hilfe des radioisotops Ca 45 in tiefgekühlter und pasteurisierter Milch. Milchwissenschaft 33, 213-215. 


\title{
Effect of preheating on behaviour of casein micelles at conditions comparable to those in ice cream
}

\begin{abstract}
During processing of ice cream, the mix is usually pasteurised. In this study the influence of heating on the structure and behaviour of casein micelles in ice cream plasma was studied. It was observed that the percentage of calcium and phosphate in the serum and the voluminosity of the casein micelles were not influenced by preheating. Compared to ice cream made from low heat milk the number average diameter was smaller and the volume surface diameter was larger in ice cream plasma made from unheated milk. The increase in number average diameter could have been due to formation of serum protein aggregates, serum protein-casein complexes or small casein particles during heating. Another possibility is that fusion of micelles during concentration was hindered by heat-induced association of serum proteins with casein micelles. The increase in volume surface diameter could be a result of increase in micelle size due to association of denatured serum proteins and/or heat coagulation. Studies on the effect of heating and concentration on casein micelle size in skim milk solutions did not lead to conclusions about the mechanism involved.
\end{abstract}




\subsection{Introduction}

Milk proteins can roughly be separated in two categories: caseins $(\sim 80 \%)$ and serum or whey proteins $(\sim 20 \%)$. Most of the caseins in milk occurs in colloidal aggregates called casein micelles. The structure and stability of casein micelles in the plasma phase of ice cream (i.e. the phase surrounding the air bubbles, fat globules and ice crystals) were studied in chapter 4 . The "ice cream mix" was made from low heat milk powder and the mix was not pasteurised. It was observed that behaviour of casein micelles in ice cream plasma at $-10^{\circ} \mathrm{C}$ did not greatly differ from casein micelles in milk. The percentage of salts associated with the micelles was slightly higher in ice cream plasma than in milk. The voluminosity of casein micelles was about the same as in milk. The average size of micelles was increased. Fewer submicelles and small micelles were observed and it was concluded that fusion of micelles must have occurred.

On industrial scale, ice cream mix is sometimes made of preheated ingredients (e.g. medium heat milk powder) and the mix is always pasteurized (e.g. $15 \mathrm{~s} 85^{\circ} \mathrm{C}$ ). Heating milk above $70^{\circ} \mathrm{C}$ causes denaturation of most serum proteins. The various serum proteins differ in heat sensitivity. The extent of denaturation of the serum proteins is affected by many factors; e.g. time and temperature of heat treatment, $\mathrm{pH}$, ionic strength, concentration of protein, concentration of calcium, and concentration of lactose (Mulvihill and Donovan, 1987). The denatured serum proteins may remain in the serum or form a complex with casein micelles. The heat-induced complex is thought to be formed between $\kappa$-casein and $\beta$-lactoglobulin or between $\kappa$-casein and heat-induced $\beta$-lactoglobulin/ $\alpha$-lactalbumine aggregates. The extent of association of denatured $\beta$-lactoglobulin and $\alpha$-lactalbumin with casein micelles depends on several factors like $\mathrm{pH}$, heating time and temperature (e.g. Oldfield et al., 1998; Visser et al., 1986). As a result of denaturation of serum proteins, their voluminosity increases. This causes an increase in viscosity of milk.

Besides denaturation of serum proteins, other chemical and physical changes occur in milk during heating. The $\mathrm{pH}$ of the milk decreases. Calcium and phosphate associate with the micelles, but these changes are for the most part reversible on cooling. Heating milk at temperatures up to $90^{\circ} \mathrm{C}$ causes only minor changes in the size of casein micelles, but severe heat treatments, such as UHT sterilisation, increase the micelle size (Singh, 1995; Walstra et al., 1999).

It is known that the properties of milk and several milk products (e.g. texture of yogurt, cheese yield, heat stability of concentrated milk) is influenced by the denaturation of serum proteins and the association of serum proteins with the micelles. Since the denaturation of serum proteins and other changes induced by preheating may also effect the properties of ice cream, the influence of preheat treatment of ice cream mix on the properties of casein micelles in ice cream plasma was studied. 


\subsection{Materials and Methods}

\subsubsection{Materials}

Preheated ice cream plasma was made in the same way as model ice cream plasma made from low heat milk (section 4.2.1). However, an additional heating and ageing step was applied. The processing was thus as follows:

1. Mixing of ingredients:

Demineralized water $71.0 \%$

Granulated sugar (CSM Suiker, Amsterdam, the Netherlands)

$16.7 \%$

Skim milk powder, low-heat (Promex, Coberco, the Netherlands)

2. Ageing for 1 night at $+2^{\circ} \mathrm{C}$.

3. Batch heating for $30 \mathrm{~min}$ at $90^{\circ} \mathrm{C}$ (plus warm up time).

4. Cooling to $+2^{\circ} \mathrm{C}$ and ageing for 1 night.

5. Freezing in a scraped surface heat exchanger without aeration. The extrusion temperature was $-5^{\circ} \mathrm{C}$.

6. Packaging in plastic cartons of $250 \mathrm{ml}$.

7. Storage at $-10^{\circ} \mathrm{C}$ for at least 2 months.

8. Pressing of $250 \mathrm{ml}$ ice cream wrapped in muslin at $20 \mathrm{bar}$ in a mechanical press at $-10^{\circ} \mathrm{C}$.

9. Two times centrifugation at $-10^{\circ} \mathrm{C}$ at an average centrifugal acceleration of $13300 \mathrm{~g}$ for 2 hours.

10. Storage at $-10^{\circ} \mathrm{C}$.

In one experiment the mix was not heated for $30 \mathrm{~min}$ at $90^{\circ} \mathrm{C}$, but at $74^{\circ} \mathrm{C}$ (step 3).

The chemical composition of preheated ice cream plasma was approximately the same as of plasma made from low heat milk. The protein content was $9.43 \%$. The percentages of various salts in the plasma were: calcium $0.345 \%$, magnesium $0.0292 \%$, phosphorus $0.310 \%$ and citrate $0.71 \%$.

Reconstituted skim milk solutions were prepared by dispersing low-heat skim milk powder (the same as used for the processing of ice cream plasma) or high-heat skim milk powder (Promex, Coberco, Lochem, the Netherlands) in various concentrations $(2.5-25 \%)$ in demineralized water. In one experiment the reconstituted skim milk solutions made from low heat milk powder were heated for $30 \mathrm{~min}$ at $90^{\circ} \mathrm{C}$ in test tubes in a water bath. To prevent bacterial growth $0.01 \%$ thiomersal (BDH Chemicals LTD) was added to the samples. To allow equilibration, the reconstituted skim milk was stirred for 24 hours at $20^{\circ} \mathrm{C}$. 


\subsubsection{Separation of the serum phase}

To determine the salt distribution over the serum and micellar phase, the plasma had to be fractionated. The serum phase of preheated plasma was obtained by ultrafiltration $(30 \mathrm{kD})$ at $10^{\circ} \mathrm{C}$ in the same way as described in section 4.2 .2 for ice cream plasma.

\subsubsection{Chemical analyses}

Calcium and magnesium contents were determined, after wet digestion, by atomic absorption spectrometry at $422.7 \mathrm{~nm}$ and $285.2 \mathrm{~nm}$, respectively. Phosphorus content was determined after wet digestion by a colorimetric method according to the International IDF Standard 42B:1990. Citric acid concentrations were enzymatically determined using a Boehringer Mannheim test kit (139076). The amounts of salts determined in permeate were recalculated to values in ice cream plasma by applying corrections for non-solvent water and volume occupied by proteins. The analyses of the various salts in ice cream plasma is described in detail in section 4.2.3.

The native serum protein nitrogen content and the non-protein nitrogen content (A) were determined in the filtrate obtained after precipitation of casein and denatured senum protein at $\mathrm{pH} 4.6$ with acetic acid and filtering through $\mathrm{S} \& \mathrm{~S} 602 \mathrm{~h}$ filter paper. The nonprotein nitrogen (B) was determined in the filtrate obtained after precipitation of proteins with TCA in a final concentration of $12 \%$ and filtering through S\&S $5951 / 2$ filter paper. The nitrogen content was determined using the macro Kjeldahl method according to IDF Standard 20B:1993. It was assumed that in an unheated skim milk made from low heat milk (un) hardly any serum proteins were denatured. The percentage of denatured serum proteins in a heated sample $\left(S_{\mathrm{h}}\right)$ was calculated as follows:

$$
S_{\mathrm{h}}=100 *\left[\left(\mathrm{~A}_{\mathrm{un}}-\mathrm{B}\right)-\left(\mathrm{A}_{\mathrm{h}}-\mathrm{B}\right)\right] /\left(\mathrm{A}_{\mathrm{un}}-\mathrm{B}\right)
$$

The amounts of $\mathrm{N}$ determined in the filtrates were recalculated to values in ice cream plasma and milk using formula 4.1 .

\subsubsection{Microscopy}

Transmission electron microscopy was used to study the appearance of the casein micelles in preheated ice cream plasma and reconstituted skim milk solutions. An outline of the procedure is given in section 4.2.6.

Casein micelles on the micrographs of preheated ice cream plasma were sized using General Image Analysis Software. 


\subsubsection{Rheological measurements}

Viscometry measurements were performed at $-10^{\circ} \mathrm{C}$ using a Bohlin CVO Rheometer, equipped with concentric cylinders. A detailed description of the procedure is given in section 4.2.5.

\subsubsection{Turbidity measurements}

By measuring the differences in turbidity of milk samples an indication of change in casein micelle size or voluminosity can be obtained. In our experiments we wanted to study the influence of concentration of milk on the casein micelle size distribution. Since the concentration of casein should be the same during the turbidity measurements, the samples had to be diluted. Because dilution of milk could influence the micelle size or voluminosity, the casein micelles were fixed before dilution. Glutaraldehyde was chosen for fixation. Carroll et al. (1968) compared several agents for fixation of casein micelles in milk and evaporated milk for electron microscopy. They concluded that glutaraldehyde preserved micelle structure better than the other fixing agents. Anderson et al. (1984) studied the effect of fixation of casein micelles in skim milk with glutaraldehyde on size and absorption profiles of fractions obtained by permeation chromatography. They concluded that the average micelle size was unaltered by fixation with glutaraldehyde and that it did not induce artefactal changes in casein micelle size.

The procedure was as follows:

1. The skim milk solutions were mixed with glutaraldehyde solution (50\%, Merck 814393 $\mathrm{S} 19788630$ ). $1.0 \mathrm{~g}$ glutaraldehyde solution was used per $10 \mathrm{~g}$ dry matter.

2. The samples were kept at rest for 1.5 hour at room temperature. A fixation time of 1.5 hours was chosen, since it was observed that for fixation times shorter than 1 hour a small increase in turbidity as a function of fixation time was obtained.

3. The solutions were diluted with demineralized water to a concentration of $1 \%$ dry matter.

4. Within 1-2 hours after dilution the turbidity was measured in a Zeiss PMQ2 spectrophotometer with an attachment for turbidity measurements. The absorbency was determined at a wavelength of $1120 \mathrm{~nm}$ in a $1 \mathrm{~cm}$ cuvette. At such a long wavelength the scattering can be described by Raleigh-Gans-Debije theory. Water was used as a blank (Nieuwenhuijse et al., 1991; Walstra, 1965).

The experiments were performed in duplicate. In the results the mean value of the two experiments is shown. 


\subsection{Results and Discussion}

\subsubsection{Denaturation of serum proteins in ice cream plasma}

The percentage of denatured serum proteins in preheated ice cream plasma as a result of heating the mix at $90^{\circ} \mathrm{C}$ for $30 \mathrm{~min}$ was approximately the same as found in the literature for milk (Table 5.1). However, if the mix was heated for $30 \mathrm{~min}$ at $74^{\circ} \mathrm{C}$, the percentage of serum proteins denatured in the plasma was much lower than observed in literature. Reconstituted skim milk was prepared from the same skim milk powder as the ice cream mix and heated for $30 \mathrm{~min}$ at $74^{\circ} \mathrm{C}$. The same percentage of denaturation of serum proteins was observed as in literature. The lower percentage of denatured serum proteins in ice cream plasma preheated at $74^{\circ} \mathrm{C}$ could be due to differences in composition. McKenna and $\mathrm{O}^{\prime}$ Sullivan (1971) observed in skim milk concentrates that denaturation of serum proteins at $75^{\circ} \mathrm{C}$ decreased with increasing total solids. It is also known that denaturation temperature of $\beta$-lactoglobulin is increased in the presence of sucrose (Boye et al., 1997). In all probability the higher concentration of milk solids and the presence of sucrose results in the lower percentage of denatured serum protein in ice cream plasma than in milk at $74^{\circ} \mathrm{C}$. At $90^{\circ} \mathrm{C}$ these factors still play a role, but in all probability due to an increase in denaturation rate of the serum proteins at $90^{\circ} \mathrm{C}$ nearly all the serum proteins were also denatured in ice cream mix after $30 \mathrm{~min}$.

Table 5.1. Percentage of denatured serum proteins in milk (literature; estimated from Larson and Rolleri, 1955), reconstituted skim milk and ice cream plasma after heating milk and ice cream mix for $30 \mathrm{~min}$ at 74 and $90^{\circ} \mathrm{C}$, nd $=$ not determined.

\begin{tabular}{llll}
\hline & Milk (literature) & Reconstituted skim milk & Ice cream plasma \\
\hline $30 \min 74^{\circ} \mathrm{C}$ & 42 & 42 & 15 \\
$30 \min 90^{\circ} \mathrm{C}$ & 81 & nd & 83 \\
\hline
\end{tabular}

\subsubsection{Salt distribution}

In Table 5.2 the percentage of salts present in the serum phase of preheated ice cream plasma is shown. The amounts of calcium, phosphorus and citrate present in the serum phase did not significantly differ between preheated ice cream plasma and ice cream plasma from low heat milk. The amount of magnesium was slightly decreased. It is known that heating milk to a temperature of perhaps $80-100^{\circ} \mathrm{C}$ causes association of calcium and phosphate with the micelles, but that these changes are to a large extent reversible on cooling (e.g. Hilgeman and Jenness, 1951; Pouliot et al., 1989a, b; Rose and Tessier, 1959). It is hard to compare the results on magnesium and citrate with literature results obtained in milk on heating. Pouliot et 
al. (1989 a, b) observed that magnesium and citrate also associate with the micelles on heating, but to a lesser extent than calcium and phosphorus. However, they could not determine the reversibility of magnesium and citrate on cooling due to variability of the results.

Table 5.2. Percentage of calcium, magnesium, citrate and phosphorus present in the serum phase of ice cream plasma made from low heat milk at $-10^{\circ} \mathrm{C}$ (ice cream $(\mathrm{h}$ ) and preheated ice cream plasma at $-10^{\circ} \mathrm{C}$ (ice cream $\mathrm{h} h$ ). The correction factor used for non-solvent water and the volume occupied by proteins in ice cream plasma was 0.879 . The data for ice cream at $-10^{\circ} \mathrm{C}$ are obtained from section 4.3.1. Between brackets the standard deviation $\sigma$ is shown.

\begin{tabular}{lll}
\hline & Ice cream lh & Ice cream hh \\
\hline $\mathrm{Ca}$ & $21(0.44)$ & $20(0.99)$ \\
\hline $\mathrm{Mg}$ & $52(0.36)$ & $46(2.3)$ \\
\hline $\mathrm{Cit}$ & $70(3.5)$ & $67(1.8)$ \\
\hline $\mathrm{P}$ & $37(3.5)$ & $38(0.70)$ \\
\hline
\end{tabular}

\subsubsection{Rheology}

The viscosities of preheated ice cream plasma, ice cream plasma obtained from low heat milk and its permeate as a function of shear rate are shown in Fig. 5.1. Heated ice cream plasma was more shear rate thinning than ice cream plasma made from low heat milk. The viscosity at a shear rate of $350 \mathrm{~s}^{-1}$ was for the serum phase $\left(\eta_{\text {serum }}\right) 0.151$ Pa.s, for ice cream plasma made from low heat milk $\left(\eta_{\mathrm{u}}\right) 0.714$ Pa.s and for the preheated ice cream plasma $\left(\eta_{\mathrm{h}}\right) 0.759$ Pa.s. The observation that heated ice cream plasma was more shear rate thinning and had a higher viscosity at high shear rates than unheated ice cream plasma can be explained by the increase in volume fraction of serum protein as a consequence of heat denaturation. 


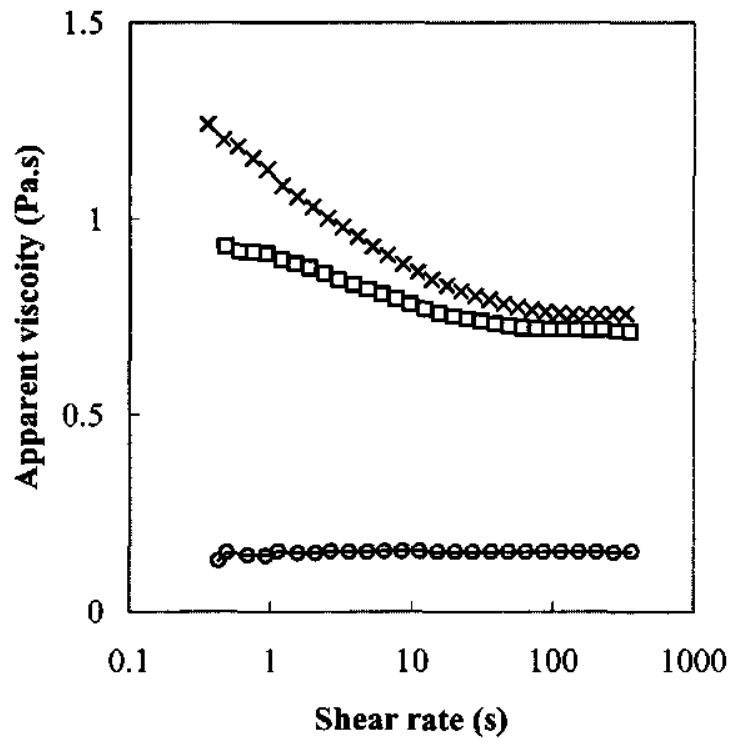

Fig. 5.1. The apparent viscosity of preheated ice cream plasma ( $x$ ), ice cream plasma made from low heat milk $(\square)$ and its permeate $(0)$ at $-10^{\circ} \mathrm{C}$. The data for ice cream plasma made from low heat milk and its permeate are obtained from section 4.3.3.

Snoeren et al. (1982) described the viscosity of unheated and heated skim milk and skim milk concentrates by the Eilers relation. Their results were used in section 4.3 .3 to determine the voluminosity of casein micelles in ice cream plasma made from low heat milk. The same calculations can be applied for heated ice cream plasma. In heated ice cream plasma the casein concentration $c_{\mathrm{c}}$ was $0.103 \mathrm{~g} / \mathrm{ml}$, the denatured senum protein concentration $c_{\mathrm{dw}}$ was $0.0156 \mathrm{~g} / \mathrm{ml}$, the native serum protein concentration $c_{\mathrm{nw}}$ was $0.0027 \mathrm{~g} / \mathrm{ml}$. Snoeren et al. (1982) found for the voluminosity of denatured serum proteins $v_{\mathrm{dw}}$ a value of $3.09 \mathrm{ml} / \mathrm{g}$. Substitution of these values in equation 4.1, 4.2 and 4.3 yields for the voluminosity of casein in heated ice cream plasma of $3.8 \mathrm{ml} / \mathrm{g}$ casein. Since the estimated voluminosity in ice cream plasma made from low heat milk was $4.0 \mathrm{ml} / \mathrm{g}$, it can be concluded that the voluminosity of casein in ice cream plasma was not markedly effected by heating.

\subsubsection{Electron microscopy of ice cream plasma}

Electron micrographs of heated ice cream plasma are shown in Fig. 5.2. If we compare this electron micrograph with those of ice cream plasma made from low heat milk (Fig. 4.3) it appears to us that more small particles were present in preheated ice cream plasma. 


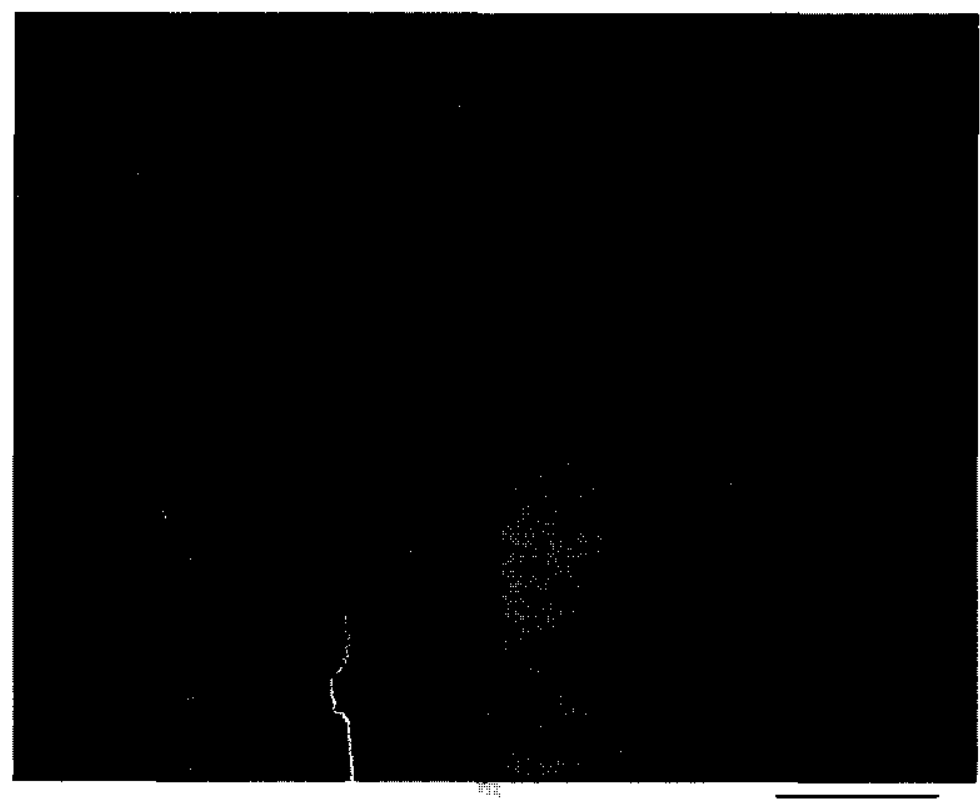

Fig. 5.2. Freeze-fracture electron micrograph (TEM) of protein particles in preheated ice cream plasma at $-10^{\circ} \mathrm{C}$ (scale bar $\left.=500 \mathrm{~nm}\right)$.

On electron micrographs 333 casein micelles were sized and size distributions parameters were estimated from these data (Buchheim et al., 1995). In Table 5.3 the results are shown and compared with those from milk and ice cream made from low heat milk.

Table 5.3. Size distribution parameters for casein micelles/protein particles in milk (Schmidt et al., 1973), ice cream plasma made from low heat milk (section 4.3.4) and preheated ice cream plasma.

\begin{tabular}{llll}
\hline & Milk & Ice cream plasma $(\mathrm{lh})$ & Preheated ice cream plasma \\
\hline$d_{10}(\mathrm{~nm})$ & 25 & 39 & 29 \\
$d_{\mathrm{vs}}(\mathrm{nm})$ & 86 & 101 & 119 \\
$c_{\mathrm{s}}(-)$ & 0.38 & 0.60 & 0.60 \\
\hline
\end{tabular}

As compared to unheated ice cream plasma, the number average diameter $d_{10}$ was decreased and the volume surface average diameter $d_{\mathrm{vs}}$ was increased. There are two possible explanations for the smaller $d_{10}$ in preheated ice cream. The first hypothesis is that during 
heating small serum protein aggregates or serum protein-casein complexes or casein particles were formed and that these particles were counted as casein (sub)micelles. Heating causes denaturation of serum proteins. Depending on conditions part of the serum proteins associate with the casein micelles and part of the denatured serum proteins form aggregates in the senum phase. Visser et al. (1986) showed that when milk was heated for 30 min at $90^{\circ} \mathrm{C}$ at $\mathrm{pH}$ 6.5 the larger part of the denatured serum proteins (about $80 \%$ ) is associated with the micelles. However, it is not known what is the partition of serum proteins at conditions as in ice cream mix ( $\mathrm{pH} \mathrm{6.48,} \mathrm{concentration} \mathrm{of} \mathrm{salts} \mathrm{and} \mathrm{proteins} \mathrm{relative} \mathrm{to} \mathrm{the} \mathrm{amount} \mathrm{of} \mathrm{water} 1.7$ times that in milk) over micelles and serum. During heat treatment, some casein (especially Kcasein) dissociates from the casein micelle. The dissociation of casein depends on many factors (e.g. pH, intensity of heat treatment, concentration of milk solids) (Singh, 1995; Singh et al., 1995). The dissociated casein may be in the form of disulfide-linked $\kappa$-casein/serum protein complexes, or casein aggregates, or monomeric protein. Besides dissociation of $\mathrm{k}$ casein, an increase in the number of small particles was observed in several studies. At the same time, an increase in the micelle size was also found. These changes have been described as representing the early stages of heat coagulation. The increase in $d_{\mathrm{vs}}$ could therefore possibly be caused by a limited heat coagulation of casein micelles. However, heat coagulation in milk usually occurs at higher temperatures and Singh and Creamer (1991) showed that during heating of milk and concentrated milk at $120^{\circ} \mathrm{C}$ at $\mathrm{pH} 6.5$ hardly any $\mathrm{K}-$ casein dissociated.

In section 4.3.4 it was suggested that in ice cream plasma made from low-heat milk, fusion of micelles occurs due to concentration during processing of the mix and freezing. The second hypothesis for the smaller $d_{10}$ in preheated ice cream plasma is that fusion in the frozen model ice cream is being hindered by the coating of micelles by denatured serum proteins. This would explain the smaller $d_{10}$ in preheated ice cream plasma as compared to ice cream plasma made from low heat milk, but it would also cause $d_{v s}$ to become smaller, whereas it was larger. As argued above the increase in $d_{\mathrm{vs}}$ due to preheating of the mix was possibly caused by a limited aggregation of casein micelles due to a kind of heat coagulation.

In both hypotheses it was postulated that the increase in $d_{v s}$ might be due to heat coagulation of casein micelles. The casein micelle size will also increase due to association of serum proteins with casein micelles. This effect alone would, however, be too small to result in the observed increase in $d_{\mathrm{vs}}$.

\subsubsection{Influence of concentration and heating on casein micelle size in skim milk solutions}

From the size distribution parameters of casein micelles in ice cream plasma, we have considered the possibility that in ice cream plasma some fusion of casein micelles takes place due to concentration and that such fusion could be hindered if the mix was preheated before 
concentration. Walstra et al. (1999) postulated a similar mechanism for the increase in casein micelle size in concentrated milk as compared to milk. However, no direct evidence could be found in literature for this hypothesis. Several studies were done on the heat coagulation of concentrated milk during sterilization and the influence of preheating on the heat stability. Data on the casein micelle distribution in concentrated and preheated concentrated milk during sterilization are present in literature, but we could not find data on casein micelle size distribution of unheated concentrated milk as a function of casein concentration.

To get a better understanding of the changes in micelle size during concentration and the influence of preheating, skim milk solutions were made from low heat and high heat milk powder. Some of the samples made from low heat milk powder were heated for $30 \mathrm{~min}$ at $90^{\circ} \mathrm{C}$. An estimate of the casein micelle size was obtained by observation of electron micrographs and by turbidity measurements.

The turbidity (expressed as optical density $E$ ) of the reconstituted skim milk solution is shown in Fig. 5.3. An increase in optical density in our experiments may be due to (Nieuwenhuijse et al., 1991):

- Increase in size of the casein micelles due to fusion. Larger particles, if of the same shape, scatter more light per unit mass. However if the particles have a more anisometric shape, the optical density is smaller due to more dependent scattering. Aggregation without fusion will therefore not greatly increase the optical density, since the effect of an increase in particle diameter will be partly compensated by the increase of dependent scattering.

- Decrease in voluminosity. Denser particles of the same dry mass scatter more light.

- Increase in mass of the particles due to association of calcium phosphate or denatured serum proteins with the micelles.

It can be seen from Fig. 5.3 that for all concentrations the optical density of a sample made from high heat milk powder was larger than from a sample of low heat milk powder of the same dry matter content. Jeurnink (1992) determined changes in casein micelle size in skim milk due to heat treatment by turbidity. He also observed an increase in turbidity and concluded that the increase in micelle size was due to association of $\beta$-lactoglobulin with casein micelles. However, the observed increase in turbidity in our experiments (by about $37 \%$ ) was much larger than the observed and calculated increase in turbidity $(8 \%)$ by Jeurnink. The difference in turbidity between the solutions must have been due to differences in the two milk powders.

For skim milk solutions made of low heat as well as of high heat milk powder, the turbidity increased with increasing skim milk powder concentration. The increase in turbidity could have been due to an increase in micelle size by fusion of micelles, a decrease in voluminosity, or association of calcium phosphate with the micelles. When the total solids content was increased above $20 \%$ the increase in optical density became much larger. The relative increase in turbidity was about the same for the solutions of low heat and high heat milk powder. Our hypothesis that fusion of micelles as a result of concentration would be 
hindered by preheating is not supported by these results. However, it was not possible to use the same concentrations of casein relative to water in the turbidity experiments as in ice cream plasma, since at these high concentrations the samples gelled during fixation with glutaraldehyde.

Heating for $30 \mathrm{~min}$ at $90^{\circ} \mathrm{C}$ of the solutions made from low heat skim milk powder caused an increase in turbidity. At low concentrations the small increase in turbidity may have been due to association of serum proteins with the micelles. At higher concentrations the increase in turbidity may also have been a result of serum protein association with micelles or to formation of serum protein aggregates or casein aggregates formed in the early stage of heat coagulation. This supports the hypothesis in section 5.3.4 that the increase in $d_{v s}$ was due to formation of protein aggregates. Solutions with a dry matter content of more than $15 \%$ could not be tested, since a gel was formed on fixation with glutaraldehyde.

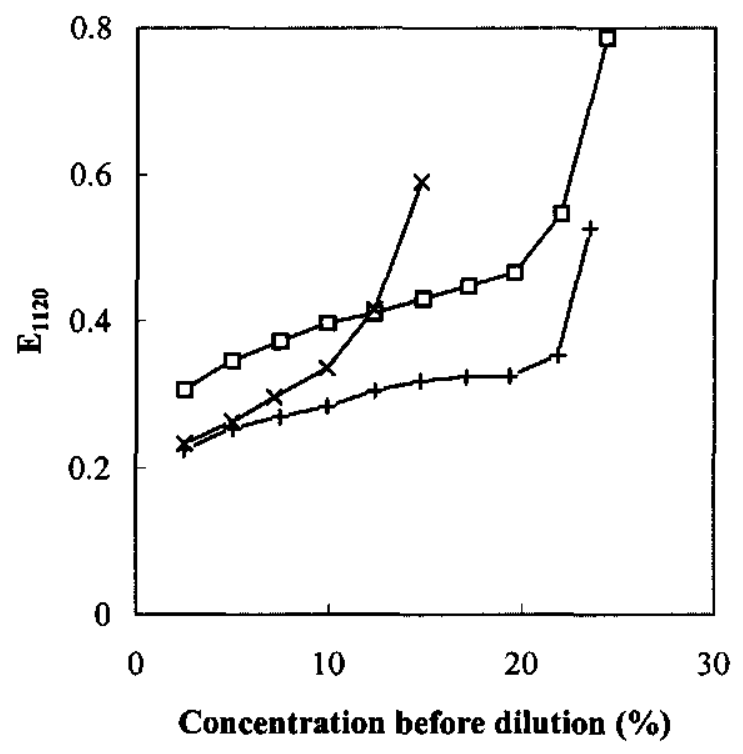

Fig. 5.3 Optical density $E$ at $1120 \mathrm{~nm}$ of skim milk solutions diluted to $1 \%$ dry matter. Before dilution the casein particles were fixed with glutaraldehyde. Skim milk solutions made of lowheat milk powder (+), high heat skim milk powder $(\square)$ and some of low-heat milk powder, when the solution was heated for $30 \mathrm{~min}$ at $90^{\circ} \mathrm{C}(\mathrm{x})$.

Electron micrographs of skim milk solutions of 10 and $20 \%$ dry matter are shown in Figs 5.4 A-D. As well as at the electron micrographs of (concentrated) skim milk made from low heat as well as from high heat milk powder solutions the size of the micelles seemed to be larger at the electron micrograph of $20 \%$ than at the one of $10 \%$ dry matter. It is hard to draw definitive conclusions from the micrographs, since it was not possible to derive reliable size 
distribution parameters from the sizing of the casein micelles because not enough particles were present.

Both the turbidity measurements and the electron micrographs support the hypothesis that fusion of casein micelles in milk can occur due to concentration. However, the same effect was observed for skim milk solutions made from low-heat and as high-heat milk powder. This does not support our hypothesis that fusion of micelles due to concentration is hindered by preheating. The difference in concentration factor between the skim milk solutions and ice cream plasma or the presence of sucrose in ice cream plasma or the difference in temperature between the two types of samples or the difference in $\mathrm{pH}$ may have caused the discrepancy in results between skim milk solutions and ice cream plasma. Therefore it is proposed to study the influence of preheating intensity, factor and method of concentration, $\mathrm{pH}$ and sucrose addition on casein micelle size distribution in more detail. At the same time the dissociation of caseins and compositions of aggregates in the serum should be determined.

\subsection{Conclusions}

The apparent viscosity of heated ice cream plasma is higher than that of ice cream plasma made from low heat milk due to denaturation of serum protein. The voluminosity of casein micelles remains about the same.

The distribution of calcium, phosphorus and citrate over micelles and serum of preheated ice cream plasma does not significantly differ from the distribution in ice cream plasma made from low-heat milk. The association of magnesium with the micelles may be slightly enhanced.

In heated ice cream plasma more submicelles and small micelles are seen on electron micrographs than in ice cream plasma made from low-heat milk. The value of $d_{10}$ is smaller, but $d_{\mathrm{vs}}$ is larger in heated plasma. The hypothesis that this is due to hindering of fusion of micelles by association of denatured serum protein in preheated plasma could not be supported by turbidity measurements and electron micrographs of skim milk reconstituted from low- and high-heat milk powder (2.5-25\%). The observed difference in micelle size distribution may also be a result of reactions occurring during the early stages of heat coagulation during the preheating of ice cream mix. 
A

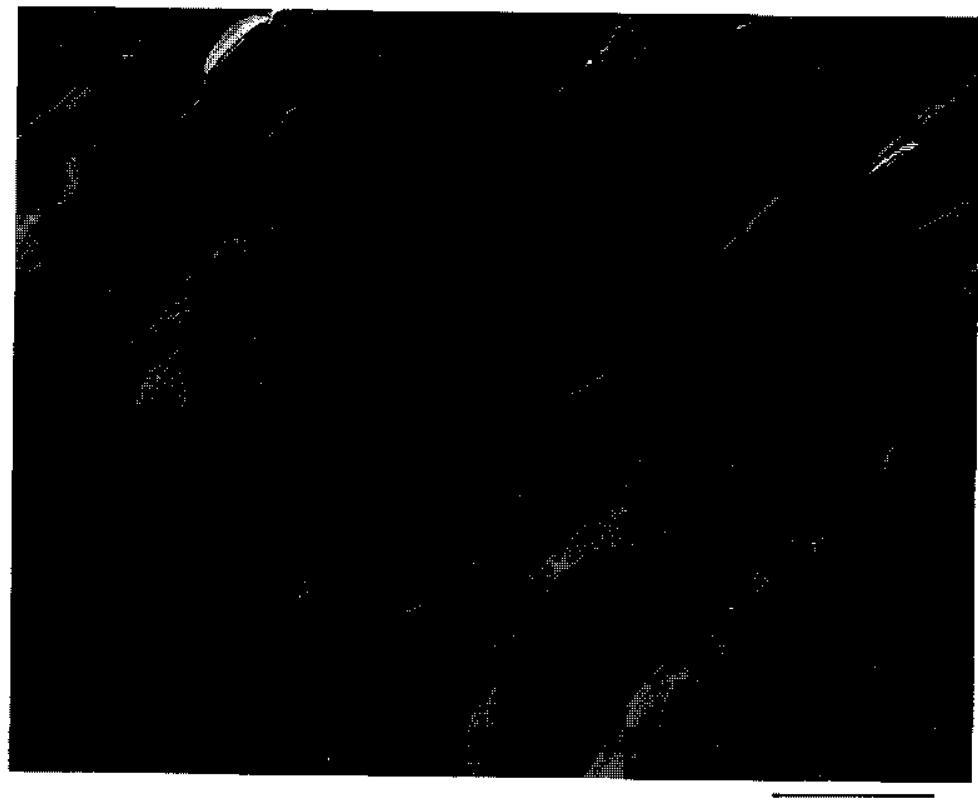

B

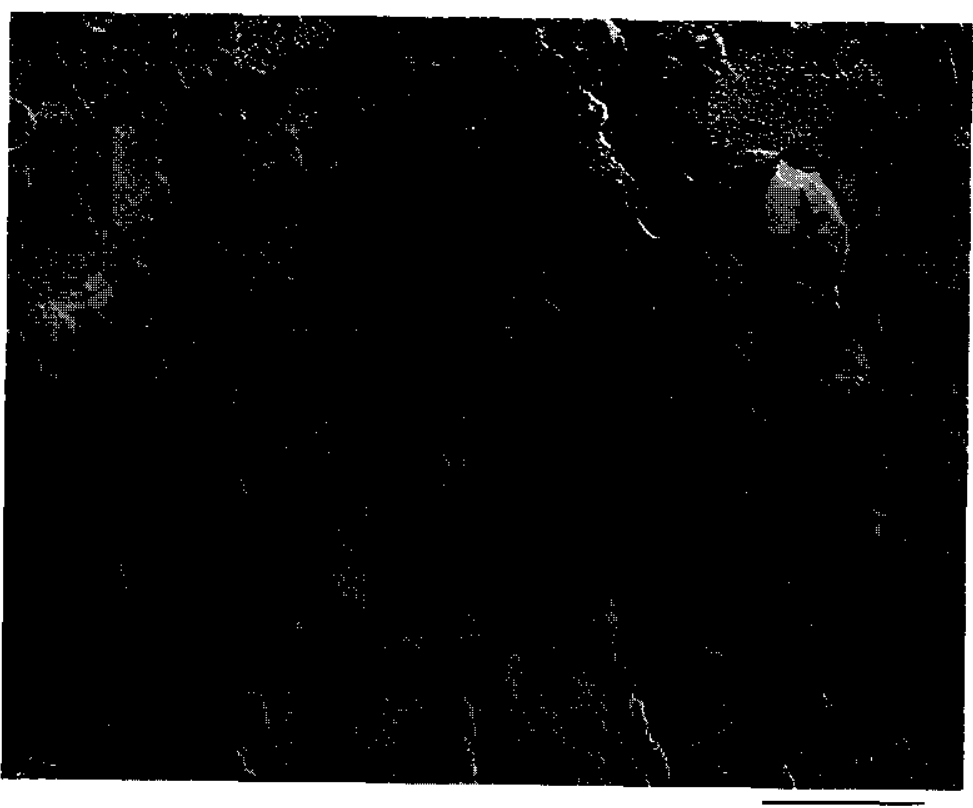

Fig. 5.4 Freeze-fracture electron micrograph (TEM) of casein micelles in reconstituted skim solutions made from low heat (h) or high heat (hh) milk powder. A. 10\% lh. B. $20 \mathrm{lh}$. (scale bar $=500 \mathrm{~nm}$ ). 
Influence of preheating on behaviour of casein micelles at conditions comparable to those in ice cream

$\mathrm{C}$

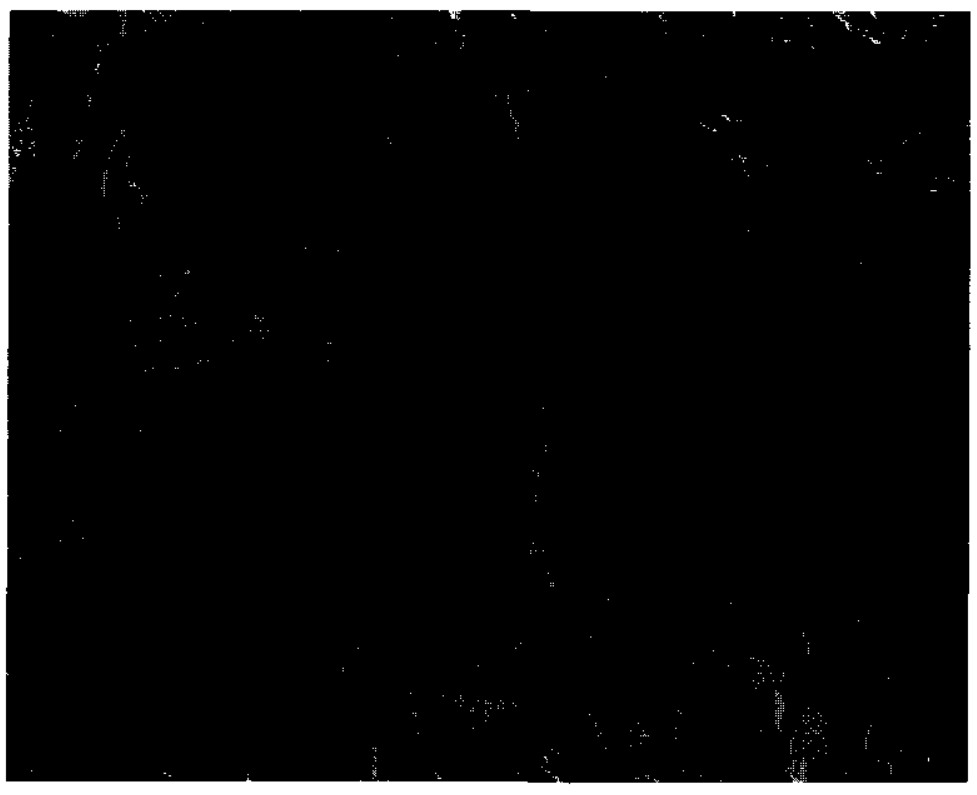

D

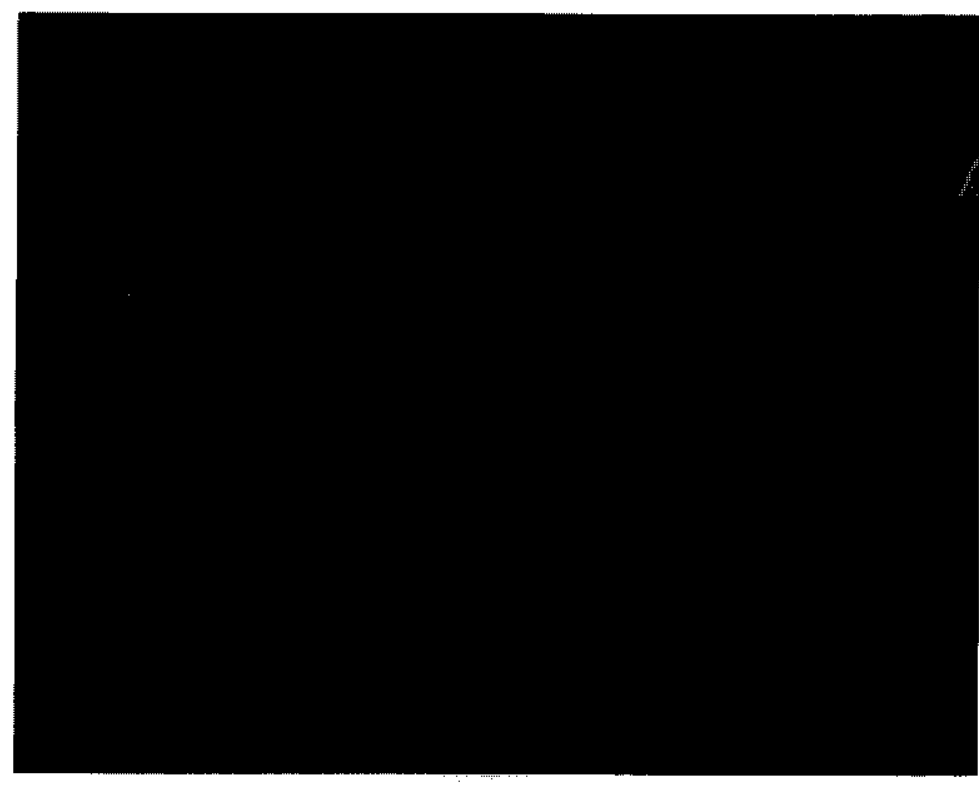

Fig. 5.4 Freeze-fracture electron micrograph (TEM) of casein micelles in reconstituted skim solutions made from low heat $(\mathrm{lh})$ or high heat (hh) milk powder. C. $10 \% \mathrm{hh}, \mathrm{D} .20 \% \mathrm{hh}$. $($ scale bar $=500 \mathrm{~nm})$. 


\section{Acknowledgements}

The authors thank Mrs J Brigham (Unilever Research Colworth Laboratory) for making the electron micrographs and former students Rachel Chow (University of Leeds) and Eldert Bruinink (Wageningen University) for doing preliminary experiments.

\section{References}

Anderson, M., Griffin, M.C.A. and Moore, C. (1984) Fixation of bovine casein micelles for chromatography on controlled pore glass. Journal of Dairy Research 51, 615-622.

Berger, K.G. and White, G.W. (1979) Ice cream. In Food Microscopy, ed. J.G. Vaughan. Academic Press, London, pp. 499-530.

Boye, J.I., Ma, C.-Y and Harwalkar, V.T. (1997) Thermal denaturation and coagulation of proteins. In Food Proteins and their applications, ed. S. Damodaran and A. Paraf. Marcel Dekker Inc., New York.

Buchheim, W., Krause, J.-P. and Rathjen, G (1995) An improved procedure for estimating size distribution parameters of spherical and non-spherical particles from their planar cross-sections. Kieler Milchwirtschaftliche Forschungsberichte 47, 177-183.

Carroll, R.J., Thomson, M.P. and Nutting, G.C. (1968) Glutaraldehyde fixation of casein micelles for electron microscopy. Journal of Dairy Science 51, 1903-1908.

Hilgeman, M. and Jenness, R. (1951) Observations on the effect of heat treatment upon the dissolved calcium and phosphorus in skimmilk. Journal of Dairy Science 34, 483-484.

Jeurnink, T.J.M. (1992) Changes in milk on mild heating: turbidity measurements. Netherlands Milk and Dairy Journal 46, 183-196.

Larson, B.L. and Rolleri, G.D. (1955) Journal of Dairy Science 38, 352.

McKenna, B.M. and O'Sullivan, A.C. (1971) Whey protein denaturation in concentrated skim milks. Journal of Dairy Science 54, 1075-1077.

Mulvihill, D.M. and Donovan, M. (1987) Whey proteins and their thermal denaturation - a review. Irish Journal of Food Science and Technology 11, 43-75.

Nieuwenhuijse, J.A., Sjollema, A., van Boekel, M.A.J.S. and Walstra, P. (1991) The heat stability of concentrated skim milk. Netherlands Milk and Dairy Journal 45, 193-224.

Olfield, D.J., Singh, H. and Taylor, M.W. (1998) Association of $\beta$-lactoglobulin and $\alpha$-lactalbumin with the casein micelles in skim milk heated in an ultra-high temperature plant. International Dairy Journal 8, 765770 .

Pouliot, Y., Boulet, M. and Paquin, P. (1989a) Observations on the heat-induced salt balance changes in milk. 1 . Effect of heating time between 4 and $90^{\circ} \mathrm{C}$. Journal of Dairy Research 56, 185-192.

Pouliot, Y., Boulet, M. and Paquin, P. (1989b) Observations on the heat-induced salt balance changes in milk. 2. Reversibility on cooling. Journal of Dairy Research 56, 193-199. 
Rose, D. and Tessier, H. (1959) Composition of ultrafiltrates from milk heated at 80 to $230^{\circ} \mathrm{F}$, in relation to heat stability. Journal of Dainy Science 42, 969-980.

Singh, H. (1995) Heat induced changes in casein, including interactions with whey proteins. In Heat induced changes in milk, ed. P.F. Fox. International Dairy Federation, Brussels, second edition.

Singh, H. and Creamer, L.K. (1991) Influence of concentration of milk solids on the dissociation of micellar Kcasein on heating reconstituted skimmilks at $120^{\circ} \mathrm{C}$. Journal of Dairy Research 58, 99-105.

Singh, H., Creamer, L.K. and Newstead, D.F. (1995) Heat stability of concentrated milk. In Heat induced changes in milk, ed. P.F. Fox, International Dairy Federation, Brussels, second edition.

Schmidt, D.G., Walstra, P. and Buchheim, W. (1973) The size distribution of casein micelles in cow's milk. Netherlands Milk and Dairy Journal, 27, 128-142.

Snoeren, T.H.M., Damman, A.J. and Klok, H.J. (1982) The viscosity of skim-milk concentrates. Netherlands Milk and Dairy Journal 36, 305-316.

Visser, J., Minihan, A., Smits, P., Tjan, S.B. and Heertje, I. (1986) Effects of $\mathrm{pH}$ and temperature on the milk salt system. Netherlands Milk and Dairy Journal 40, 351-368.

Walstra, P. (1965) Light scattering by milk fat globules. Netherlands Milk and Dairy Journal 19, 93-109.

Walstra, P., Geurts, T.J., Noomen, A., Jellema, A. and van Boekel, M.A.J.S. (1999). Dairy technology: Principles of milk, properties and processes. Marcel Dekker Inc., New York. 


\title{
Behaviour of casein micelles at conditions comparable to those in frozen yoghurt
}

An abridged version of this chapter has been published by M.J. Jonkman, P. Walstra, M.A.J.S. van Boekel and D.J. Cebula in International Dairy Journal, 9, 385-386, 1999.

\begin{abstract}
In some ice cream products (e.g. frozen yoghurt, yoghurt ice) yoghurt is used as an ingredient. In this study the behaviour of casein micelles in a model frozen yoghurt plasma was reported. Nearly all the calcium and inorganic phosphorus was present in the serum phase of the frozen yoghurt plasma. Frozen yoghurt plasma formed a gel during storage, suggesting a network of casein to be present. On electron micrographs aggregates of casein particles could be seen. After 10 months storage cracks in the gel were observed and the rheological properties had changed too. Dynamic measurements were done in strongly presheared gels, and the storage modulus was observed to increase during the measurements. Between 8 and 10 months of storage the magnitude of this increase was reduced by about $90 \%$. In all probability these changes in time are due to rearrangement of the casein network.
\end{abstract}




\subsection{Introduction}

The structure and stability of casein micelles in ice cream is hardly known and hard to predict. In chapter 4 the behaviour of casein micelles in the plasma phase of ice cream (i.e. the phase surrounding the air bubbles, fat globules, ice crystals and lactose crystals) was studied. The structure and behaviour of casein micelles in ice cream plasma at $-10^{\circ} \mathrm{C}$ did not differ greatly from casein micelles in milk. The properties of casein micelles in ice cream plasma could be explained by a combination of two conditions which differ significantly from those in milk: high concentration of solutes and low temperature.

In practice, in the processing of some ice cream products yoghurt is used as an ingredient. These products are usually called frozen yoghurt or yoghurt ice. There are many different recipes for frozen yoghurt. Depending on the taste of the consumer in a certain geographical region and on the legislation in a country, the percentage and type of yoghurt used, the pH of the frozen yoghurt and the level of live lactic acid bacteria vary. In the USA, frozen yoghurt normally has a low percentage of yoghurt (5-30\%) and therefore a rather high $\mathrm{pH}$ (5.5-6.5). In Western Europe, usually more yoghurt is added and the $\mathrm{pH}$ of frozen yoghurt usually varies between 4.0 and 5.5 (Olsen, 1990; Pleit, 1994; Westerbeek, 1995).

Yoghurt manufacture involves inoculating milk with lactic acid bacteria. One of the products formed during fermentation is lactic acid. Acidification causes two major physical processes to occur: colloidal calcium phosphate dissociates from the micelles and the casein aggregates. The calcium and phosphate go into sollution as a result of the protonation of the ionized phosphate and carboxyl groups. At temperatures below $25^{\circ} \mathrm{C}$ this results in dissociation of a portion of all caseins from the micelles. At $\mathrm{pH}$ values around 5.0, the caseins precipitate isoelectrically (Dalgleish, 1997). The final $\mathrm{pH}$ of fresh yoghurt is usually between 4.1 and 4.6.

We are not aware of research results on the behaviour of casein micelles in frozen yoghurt. The combined effect of low $\mathrm{pH}$, concentration and low temperature on the behaviour of casein micelles is not known. Therefore, the influence of lowering $\mathrm{pH}$ on behaviour of casein micelles in model frozen yoghurt plasma was studied.

\subsection{Materials and Methods}

\subsubsection{Materials}

In practice, real yoghurt is used as an ingredient in the manufacture of frozen yoghurt. This means that besides lactic acid other metabolites (e.g. exopolysaccharides) are added, which may complicate the interpretation of the results. Hence, it was decided to use lactic acid for acidification of ice cream mix. The $\mathrm{pH}$ of the mix was decreased to $\mathrm{pH} 4.0$. 
The manufacture of frozen yoghurt is usually like that of ice cream. Therefore, the method for producing model frozen yoghurt plasma was kept as similar as possible to that for our reference ice cream plasma made from low heat milk (section 4.2.1):

1. Mixing of ingredients. The recipe was as follows (the amounts are expressed as $\%$ of the total mix, see 3):

Demineralized water $51.1 \%$

Granulated sugar (CSM Suiker, Amsterdam, the Netherlands)

Skim milk powder low heat (Coberco, Lochem, the Netherlands)

Although in practice yoghurt is made from high-heat milk, we used low-heat milk powder to be able to make a correct comparison with our reference ice cream plasma.

2. Ageing for 1 night at $+2^{\circ} \mathrm{C}$.

3. Acidification. To avoid formation of a precipitate of casein, lactic acid solution (5\%) was slowly poured in the mix at $+2^{\circ} \mathrm{C}$. The final percentage of lactic acid solution in the mix was $19.9 \%$. After acidification, the mix was slowly warmed up from $+2^{\circ} \mathrm{C}$ to $+30^{\circ} \mathrm{C}$ in a water bath under periodic stirring. As a result the casein aggregated.

4. Freezing in a scraped surface heat exchanger without aeration. The extrusion temperature was $-5^{\circ} \mathrm{C}$.

5. Packaging in plastic cartons of $250 \mathrm{ml}$.

6. Storage at $-10^{\circ} \mathrm{C}$. Except for one experiment, the product was stored for at least 2 months to crystallise all lactose that can crystallise at that temperature.

7. Pressing of $250 \mathrm{ml}$ of ice cream wrapped in muslin at 20 bar in a mechanical press at $10^{\circ} \mathrm{C}$ to obtain frozen yoghurt plasma without most of the ice crystals.

8. Storage at $-10^{\circ} \mathrm{C}$.

The centrifugation step used in processing of ice cream plasma was not applied, since this was not effective due to the high viscosity of the frozen yoghurt plasma. Therefore the obtained frozen yoghurt plasma contained most of the lactose crystals and some of the smaller ice crystals.

The composition of the frozen yoghurt plasma was as follows: water $44.52 \%$, sucrose $31.8 \%$, lactose $9.57 \%$, casein $6.69 \%$, whey protein $1.27 \%$, calcium $0.310 \%$, magnesium $0.030 \%$, phosphorus $0.266 \%$ and citrate $0.520 \%$.

\subsubsection{Separation of the serum phase}

To determine the salt distribution over the serum and micellar phase, the plasma had to be fractionated. The serum phase of frozen yoghurt plasma was obtained by ultrafiltration (30 $\mathrm{kD})$ at $-10^{\circ} \mathrm{C}$. The same ultrafiltration procedure as described in chapter 4.2 .2 was used. The processing and fractionation of frozen yoghurt plasma was performed in duplicate. 


\subsubsection{Chemical analyses}

Calcium and magnesium contents were determined after wet digestion by atomic absorption spectrometry at $422.7 \mathrm{~nm}$ and $285.2 \mathrm{~nm}$, respectively. Phosphorus content was determined after wet digestion by a colorimetric method according to the International IDF Standard 42B:1990. Micellar organic phosphate was determined as total phosphorus minus phosphorus in filtrate of TCA. Citric acid concentrations were enzymatically determined using Boehringer Mannheim 139076 test kit. After precipitation of proteins lactose was determined in the filtrate using using Boehringer Mannheim 176303 test and sucrose using Boehringer Mannheim 139041 test. Details about these analyses are given in chapter 4.2.3.

The amounts of salts and sugars determined in permeate were recalculated to values in ice cream plasma and milk by applying the corrections for non-solvent water, volume occupied by proteins (see chapter 4.2 .3 ) and the ice and lactose crystals that were still present in the plasma.

All analyses were performed at least in duplicate. In the results the mean value is shown.

\subsubsection{Calcium ion activity}

The calcium ion activity was measured at room temperature after equilibration for two days at room temperature. To prevent bacterial growth, 0.01\% thiomersal (BDH Chemicals LTD) was added to the samples. Details of the measurement of the calcium ion activity are given in chapter 4.2.4.

\subsubsection{Determination of proteins}

The casein and whey protein content are calculated from the total, non protein and non casein nitrogen content. The nitrogen content was determined using the macro Kjeldahl method. Details about these analyses are given in chapter 4.2.3.

The individual caseins in ice cream and frozen yoghurt plasma were determined in two ways; with reversed phase HPLC and with SDS-PAGE. In reversed phase HPLC the separation is based on difference in hydrophobicity and size of the different fractions. In SDSPAGE the fractions are separated by size.

For determination of individual caseins with reversed phase HPLC the method described by Visser et al. (1991) was used as a basis. However, the clarification of the samples, the composition of the eluents, the gradient used and the column temperature were modified. The samples were clarified by diluting the samples $1: 1$ (v:v) with a buffer solution 
containing $0.2 \mathrm{M}$ Tris(hydroxymethyl)aminoethane, $4 \mathrm{M}$ urea and $0.3 \%$ dithiothreitol. After standing at room temperature for 1 hour, the samples were diluted 1:7 (v:v) with eluent $A$ containing $6 \mathrm{M}$ urea. After filtration through a $0.2 \mu \mathrm{m}$ filter, $20 \mu \mathrm{l}$ of sample was injected. Eluent A was acetonitrile-water-trifluoroacetic acid (100:900:1 v:v:v) and eluent B was the same mixture with the proportions 900:100:1 (v:v:v). A HiPore RP-318 column (Biorad, 250 $\mathrm{x} 4.6 \mathrm{~mm}$ ) was used. The eluent gradient was: starting from $73 \%$ of $\mathrm{A}$ for $35 \mathrm{~min}, 60 \%$ for 20 $\min , 50 \%$ for $2 \mathrm{~min}, 30 \%$ for $8 \mathrm{~min}$ and $73 \%$ for $5 \mathrm{~min}$. The column temperature was $35^{\circ} \mathrm{C}$. The flow rate $0.8 \mathrm{ml} / \mathrm{min}$. The casein fractions were detected with UV-adsorbance at $220 \mathrm{~nm}$.

For SDS-PAGE samples were diluted with buffer ( $10 \mathrm{mM}$ Tris, $1 \mathrm{mM}$ EDTA, pH 8.0). To the diluted samples sodium dodecyl sulphate was added to $2.5 \%$, mercaptoethanol to $5.0 \%$, bromophenol blue to $0.01 \% \mathrm{ml}$ and bovine serum albumin to $0.5 \%$. The samples were heated for $10 \mathrm{~min}$ at $100^{\circ} \mathrm{C}$. After heating undissolved material was removed by centrifugation. A part of the supernatant was loaded onto a $20 \%$ homogeneous Phastgel (Pharmacia) and subjected to electrophoresis at $250 \mathrm{~V}$ for $195 \mathrm{Vh}$ at $15^{\circ} \mathrm{C}$. The gels were then coomassie stained $(0.2 \%$ PhastGel Blue R, 30\% methanol, $10 \%$ acetic acid) in the PhastSytem and destained (30\% methanol, 10\% acetic acid) using the method described in development technique file number 200 'Fast Coomassie staining' (Pharmacia).

\subsubsection{Microscopy}

Transmission electron microscopy was used to study the appearance of the casein particles. The samples were prepared in two ways: freeze-fracturing and freeze-substitution. The details of the freeze-fracturing and -etching procedure are described in chapter 4.2.6. The samples were freeze-substituted in a Reichert automatic freeze-substitution system. The ice was first replaced by methanol and after that by a resin. The resin used was Lowicryl hm 20 . The freeze-substituted samples were histochemically stained for total protein. Micrographs were taken using a Jeol 1200EXII transmission electron microscope operated at $80 \mathrm{kV}$. Micrographs were taken at X20,000 (microscope magnification) and printed X4 (i.e. 80,000).

\subsubsection{Rheological measurements}

To study the formation of a gel, dynamic rheological measurements were performed at $-7^{\circ} \mathrm{C}$ for 7 or 11 days using a Bohlin CVO Rheometer. The measurements were performed at $-7^{\circ} \mathrm{C}$ and not at $-10^{\circ} \mathrm{C}$, since at $-10^{\circ} \mathrm{C}$ still some ice crystals were present that could disturb the measurements. The procedure of the measurement is described in section 4.2.5. 
After one of the dynamic measurements a stress sweep was applied to determine the fracture strain at $-7^{\circ} \mathrm{C}$. The frequency was $0.1 \mathrm{~Hz}$. The starting stress was $0.02464 \mathrm{~Pa}$ and the stress was increased in $1143 \mathrm{~s}$ in 88 steps to a maximum of $307 \mathrm{~Pa}$.

\subsection{Results and Discussion}

Frozen yoghurt plasma can be seen as a kind of sweetened condensed milk of $\mathrm{pH} 4.0$, which is concentrated and stored at a low temperature. It is known that nearly all the calcium and inorganic phosphorus in milk at $\mathrm{pH} 4.8$ is present in the serum phase. Between 4 and $30^{\circ} \mathrm{C}$ there is no influence of temperature on the dissociation of salts at this pH (Dalgleish and Law, 1989). Data of milk at lower $\mathrm{pH}$ values and temperatures are not available. In contrast to lowering $\mathrm{pH}$ at low temperatures, concentration of milk at physiological $\mathrm{pH}$ leads to association of calcium phosphate with the micelles (Nieuwenhuijse et al., 1988; Pouliot and Boulet, 1995). It can be seen in Table 6.1 that the effects of low $\mathrm{pH}$, low temperature and concentration in frozen yoghurt plasma results in dissociation of nearly all the $\mathrm{Ca}$, inorganic $\mathrm{P}, \mathrm{Mg}$ and citrate of the micelles. The $\mathrm{pH}$ effect was much stronger than the concentration effect. The percentage of calcium and magnesium that was not found in the serum phase had in all probability precipitated on the surface of and inside the ultrafiltration membrane. Citrate could also be precipitated in this way, but could also be present as counterions. The phosphorus that was still present in the casein particles $(29 \%)$ was slightly more than the percentage of phosphorus that is esterified to proteins (i.e. organic micellar phosphate $23 \%$ ). This could also be due to precipitation or the presence of phosphate as counterions in the micelles. No change in salt distribution in time was observed.

The calcium ion activity of frozen yoghurt plasma after 9 months storage at $-10^{\circ} \mathrm{C}$ was high: $12.0 \mathrm{mmol} / 1$.

Table 6.1. Percentage of calcium, magnesium, citrate and phosphorus present in the serum phase of frozen yoghurt at $-10^{\circ} \mathrm{C}$. The correction factor used for non-solvent water, the volume occupied by proteins, ice and lactose crystals in frozen yoghurt was 0.81 . The data for milk at room temperature $(r T)$ and ice cream at $-10^{\circ} \mathrm{C}$ are obtained from chapter 4 . Between brackets the standard deviation $s$ is shown.

\begin{tabular}{llll}
\hline & Milk at rT & Ice cream & Frozen yoghurt \\
\hline $\mathrm{Ca}$ & $26(0.38)$ & $21(0.44)$ & $97(1.4)$ \\
$\mathrm{Mg}$ & $58(2.5)$ & $52(0.36)$ & $97(2.9)$ \\
\hline $\mathrm{Cit}$ & $84(5.0)$ & $70(3.5)$ & $87(2.3)$ \\
$\mathrm{P}$ & $40(2.7)$ & $37(3.5)$ & $71(2.5)$ \\
\hline
\end{tabular}


As expected, after acidification of the mix (processing step 3) casein aggregates could be observed. After pressing frozen yoghurt plasma (processing step 7), it was a liquid. However, a gel was formed in the plasma during storage. This suggests that a network of casein was formed. On electron micrographs of frozen yoghurt stored for about 4 months (Figs. 6.1 and 6.2) large aggregates of casein particles could be seen. Since a gel was formed during storage and since in milk lowering $\mathrm{pH}$ also leads to aggregation of casein micelles, this was expected. On Fig. 6.1 also lactose crystals can be seen.

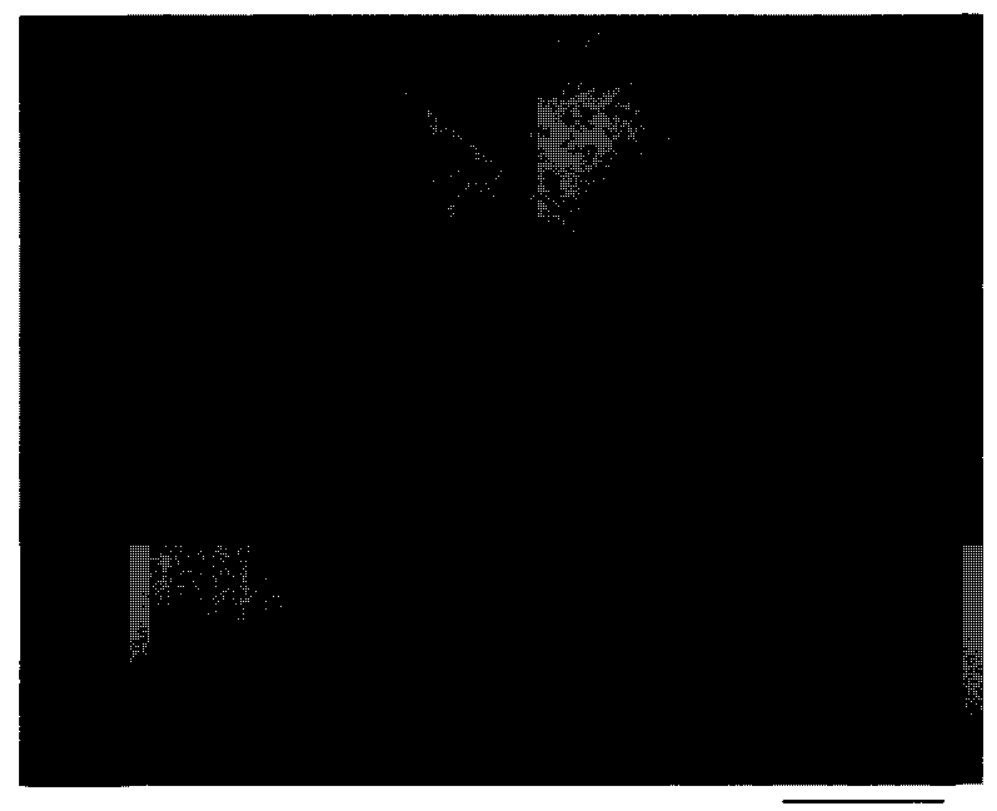

Fig. 6.1. Freeze-substitution electron micrograph (TEM) of lactose crystals and casein particles in frozen yoghurt plasma at $-10^{\circ} \mathrm{C}$ (scale bar $\left.=5 \mu \mathrm{m}\right)$. 


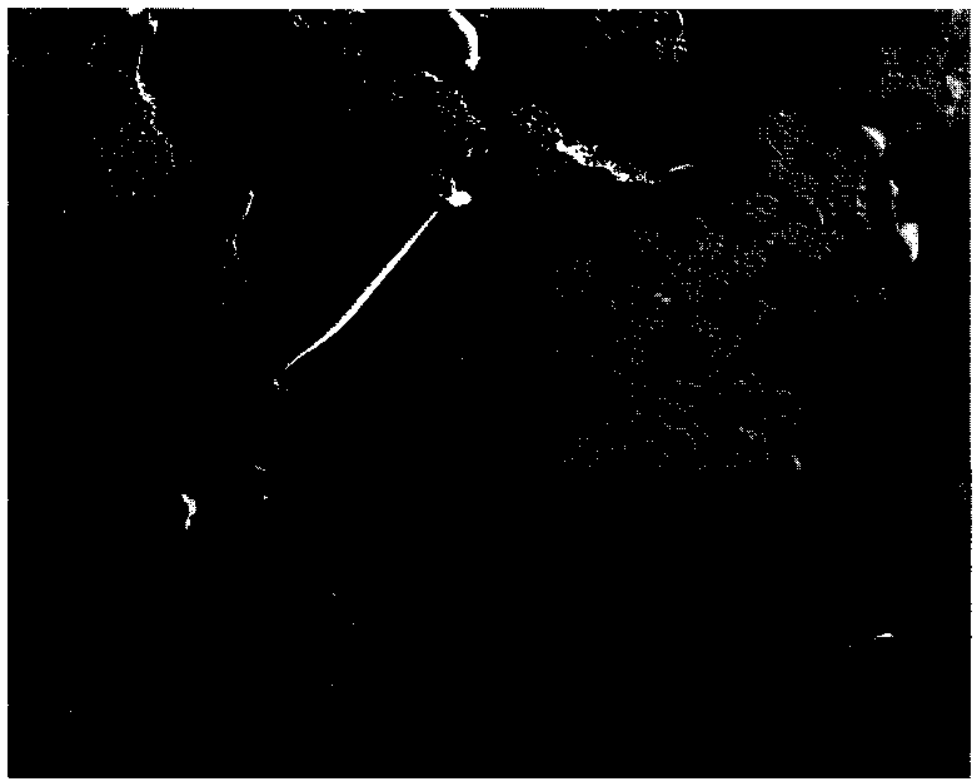

Fig 6.2. Freeze-fracture electron micrograph (TEM) of casein particles in frozen yoghurt plasma at $-10^{\circ} \mathrm{C}$ (scale bar $\left.=500 \mathrm{~nm}\right)$.

After breaking up the frozen yoghurt plasma gel, a gel was formed again during storage. This was also observed during dynamic rheological measurements which were performed after 8 months storage at $-10^{\circ} \mathrm{C}$. As can be seen from Fig. 6.3 the storage and loss moduli increased linearly in time. However, the phase angle decreased during the first hours to remain around $11^{\circ}$ for the rest of the time. This implies that the number of bonds increased and that the nature of the bonds that contribute to the modulus did not change after the first hours (Walstra and Van Vliet, 1986).

After about 10 months, the same experiments were performed again. It was also found that the moduli increased in time but the moduli were much lower than after 8 months storage. From Fig. 6.3 it can be observed that after 10 months storage the slope of the line expressing the dependence of the storage modulus on the measurement time was decreased to $10 \%$ of the slope after 8 months storage. 


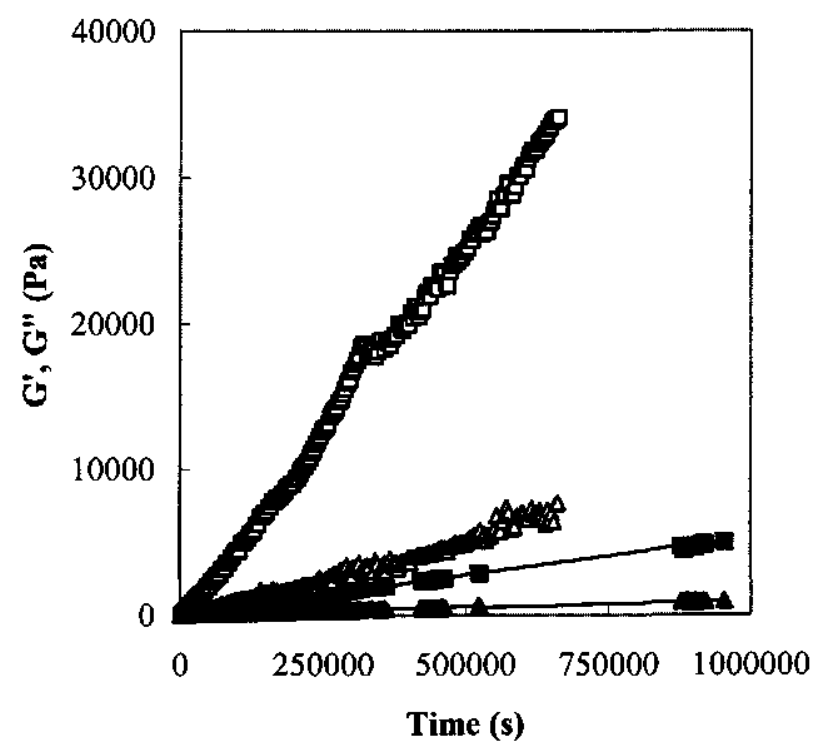

Fig. 6.3. Storage modulus $(\square, \square)$ and loss modulus $(\Delta, \mathbf{\Delta})$ at $-7^{\circ} \mathrm{C}$ of frozen yoghurt plasma stored for eight $(\square, \Delta)$ and ten $(\boldsymbol{\square}, \mathbf{\Delta})$ months as a function of time after preshearing.

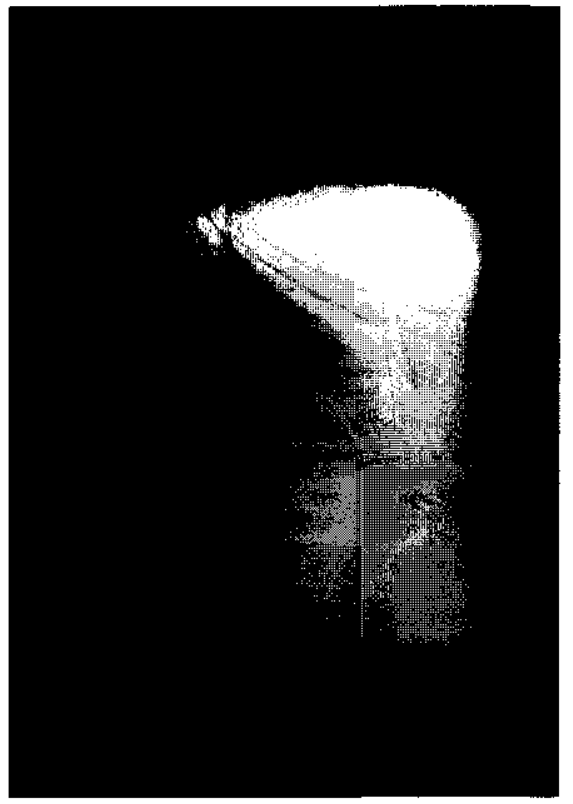

Fig. 6.4. Frozen yoghurt plasma in a jar (height $8 \mathrm{~cm}$ ) after 10 months storage at $-10^{\circ} \mathrm{C}$ 
The change in structure of the network could also be observed visually. Frozen yoghurt plasma stored for about 4 months was a gel ("pudding"). However after storage for 10 months it was not a gel anymore, but a liquid with a high viscosity ("porridge"). The gels were stored in jars and after 10 months storage cracks in the gel were observed (Fig. 6.4). It can be seen from Fig. 6.4 that the cracks were straight. This indicates that the cracks developed fast and that the material was brittle. A fracture strain experiment, which was performed after the dynamic measurements after eight months storage, showed that the material was quite brittle (Fig. 6.5). If we take the fracture strain as the strain at which the moduli show a sudden sharp fall (Van Vliet and Keetels, 1995), the fracture strain was about 0.004 and the fracture stress about $100 \mathrm{~Pa}$.

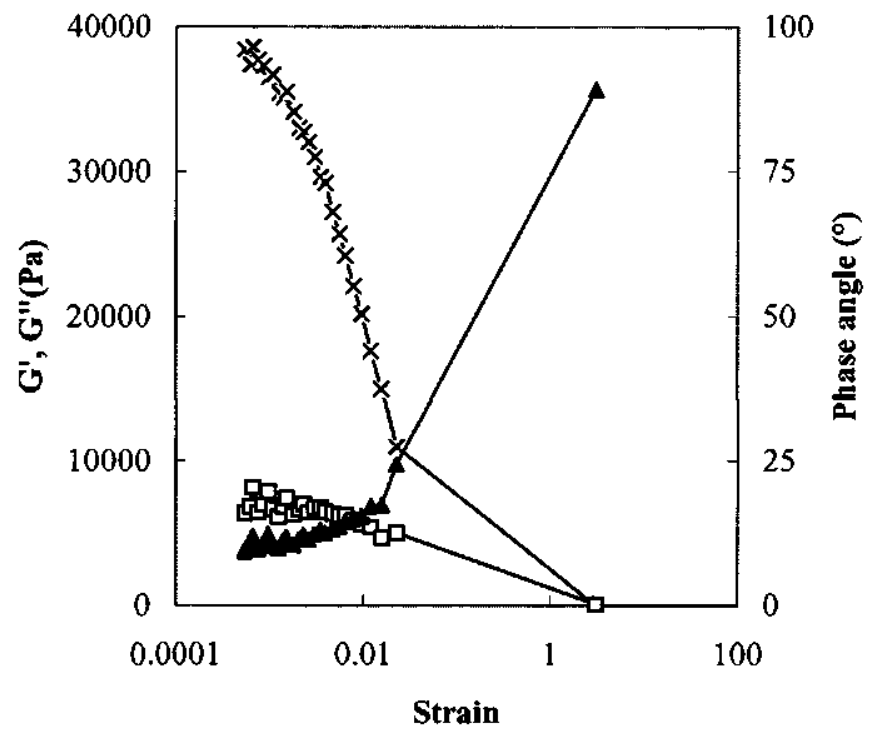

Fig. 6.5. Storage (x) modulus, loss moduli ( $\square$ ) and phase angle ( $\mathbf{\Delta}$ ) as a function of strain of frozen yoghurt plasma gel stored for 8 months at $-10^{\circ} \mathrm{C}$. The measurements were performed after dynamic measurements for 7 days.

Two possible explanations were considered for the change in rheological properties. The first explanation is enzymatic hydrolysis of caseins. It is known that in milk a protease at low $\mathrm{pH}$ can be active. This so called acid milk proteinase has a $\mathrm{pH}$ optimum of 4.0 and mainly hydrolyzes $\alpha_{s}$-casein (Kaminogawa and Yamauchi, 1972). If the proteinase was active in ice cream plasma, degradation products should have been formed. In Fig. 6.6 the chromatogram of fresh (one month) and old (ten months) frozen yoghurt plasmas are shown. The heights of the peaks of the individual caseins were slightly higher for fresh than for old frozen yoghurt plasma. This could be due to experimental error. The relative heights of the peaks for the 
different caseins were, however, the same. On SDS-PAGE gels difference between ice cream and frozen yoghurt plasmas could not be observed. Both techniques for determination of individual caseins showed no difference between fresh and old frozen yoghurt plasma. It may therefore be concluded that no degradation products of casein were formed by hydrolysis. The hypothesis that the change in rheological behaviour of frozen yoghurt plasma was caused by hydrolysis of casein by acid milk proteinase could therefore be rejected.

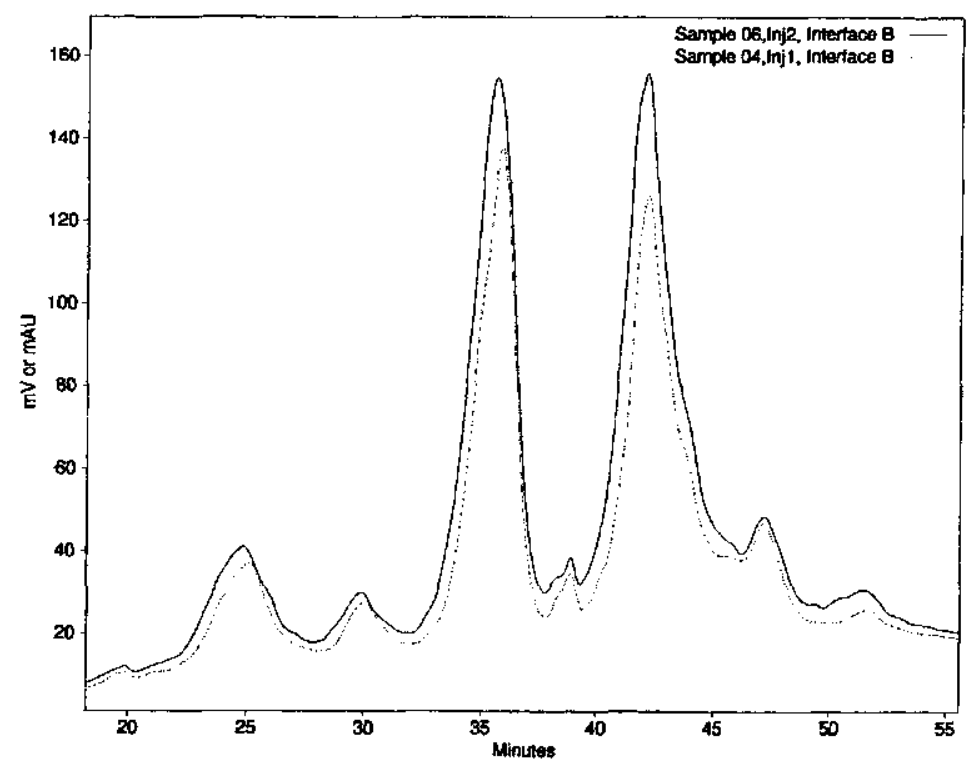

Fig. 6.6. Chromatogram of proteins in frozen yoghurt plasma stored after one (-) and ten months (...) at $-10^{\circ} \mathrm{C}$.

The second explanation is that rearrangement of the casein particle network occurred. It is assumed that after processing casein particles in the frozen yoghurt gel form junctions with a limited number of other particles. Rearrangement of the particles into large aggregates and a more compact network will increase the number of bonds and hence decrease the total free energy. These rearrangements may involve fracture of casein strands which may lead to the formation of cracks. Such a crack may then grow and become visible. The formation of larger aggregates would imply that larger pores were present. This would explain the lower increase in modulus after 10 months of storage. The proposed mechanism resembles syneresis of skim milk gels. In general, acid milk gels show little or no syneresis. However, it is known that milk gels at $\mathrm{pH} 4.1$ and lower show syneresis at room temperature (Van Vliet and coworkers, unpublished results). 
It is known that slow shrinkage with time is more pronounced in frozen yoghurt with a high yoghurt content than in ice cream. One of the reasons for this could be a rearrangement of the casein network in frozen yoghurt in time.

\subsection{Conclusions}

The serum of frozen yoghurt plasma contains nearly all of the inorganic phosphorus, calcium, magnesium and citrate. This means that the effect of $\mathrm{pH}$ on the salt distribution is much stronger than the effect of concentration.

Frozen yoghurt plasma forms a gel during storage. A network of casein particles is present. During storage, the rheological properties of the gel changed and cracks in the gel were observed after 10 months of storage. In all probability, these changes are due to rearrangement of the casein particle network.

\section{Acknowledgements}

The authors thank Mr C. Smith (Unilever Research Colworth Laboratory) for making electron micrographs, Mrs M.A.H. Baltussen (Wageningen University) for performing the calcium and phosphorus analyses and the then student Clare Brooks for doing preliminary measurements.

\section{References}

Dalgleish, D.G. and Law, A.J.R. (1989) pH-induced dissociation of bovine casein micelles. 2. Mineral solubilization and its relation to casein release. Journal of Dairy Research 56, 727-735.

Dalgleish, D.G. (1997) Structure-function relationships of caseins. In Food Proteins and their applications, eds. S. Damodaran and A. Paraf, Marcel Dekker Inc., New York.

Kaminogawa, S. and Yamauchi, K. (1972) Acid protease of bovine milk. Agricultural and biological chemistry 36, 2351-2356.

Nieuwenhuijse, J.A., Timmermans, W. and Walstra, P. (1988) Calcium and phosphate partitions during the manufacture of sterilized concentrated milk and their relations to the heat stability. Netherlands Milk and Dairy Journal 42, 387-421.

Olsen, S. (1990) Frozen yogurt. Grindsted Technical Paper T218-1e. Denmark: Grindsted Products.

Pleit, J. (1994) Yoghurt ice: Market, Legislation, Recipes and Processing. Proceedings of Inter-Eis '94, Solingen.

Pouliot, Y. and Boulet, M. (1995) Observations on the seasonal variations in the salt balance of concentrated milk. International Dairy Journal 5, 75-85. 
Stadhouders, J. and Mulder, H. (1957) Fat hydrolysis and cheese flavour. 1. The enzymes responsible for the hydrolysis of fat in cheese. Netherlands Milk and Dairy Journal 11, 164-183.

Van Vliet, T. and Keetels, C.J.A.M. (1995) Effect of preheating of milk on the structure of acidified milk gels. Netherlands Milk and Dairy Joumal 49, 27-35.

Visser, S., Slangen, C.J. and Rollema, H.S. (1991) Phenotyping of bovine milk proteins by reversed-phase highperformance liquid chromatography. Joumal of Chromatography 548, 361-370.

Walstra, P. and Jenness, R. (1984) Dairy Chemistry and Physics. John Wiley \& Sons, New York.

Westerbeek, H. (1995) Frozen yogurt: the way ahead. Dairy Industries International 60, 39-41. 


\title{
7
}

\section{The effect of various cations on aggregation of casein micelles in the cold}

This chapter was submitted for publication by M.J. Jonkman, T. van Vliet, P. Walstra and D.J. Cebula.

\begin{abstract}
The influence of type of acidulant, addition of various salts, concentration and preheat treatment on aggregation of casein micelles in the cold was studied. It was observed that skim milk and concentrated skim milk acidified with GDL formed a gel at pH 4.8 and lower. Skim milk acidified with $\mathrm{HCl}$ formed a precipitate at $\mathrm{pH} 4.5$ and lower. It was shown that the $\mathrm{pH}$ of aggregation is related to the divalent cation activity. Skim milk acidified with GDL had a lower calcium ion activity than skim milk acidified with $\mathrm{HCl}$, probably due to association of calcium with gluconate ions. Increasing the divalent cation activity of skim milk prior to acidification with GDL resulted in a decrease in firmness of the acidified skim milk gels. The same observations were found for preheated skim milk. Two hypotheses are postulated for the observed effect of divalent cations on aggregation of micelles in the cold.
\end{abstract}




\subsection{Introduction}

About $80 \%$ of the proteins in milk are caseins. Very little of the casein in uncooled milk is in monomeric form. By far the greater part is in colloidal particles called casein micelles. Besides casein, the micelles contain water, salts (for the most part calcium phosphate) and some enzymes. The main forces that maintain caseins in the micellar state are hydrophobic interactions and interactions with calcium phosphate (Thompson, 1973; Walstra and Jenness, 1984). In milk casein micelles are very stable. They may aggregate when conditions change. Aggregation mostly leads to the formation of a gel or a precipitate. At room temperature the stability against aggregation is primarily due to steric and electrostatic repulsion, caused by protruding chains ("hairs") of the C-terminal part of $\kappa$-casein. The hairs on different casein micelles may touch, however, and this may in some situations lead to lasting contact of the micelles, i.e. aggregation. Aggregation can occur for instance at high temperature, on freezing, rennetting, ethanol addition and at low pH (Walstra, 1990).

Much is known about the effect of acidification on the composition, structure and stability of casein micelles and the rheological properties of the gels formed at ambient temperatures. Casein micelles change considerably if $\mathrm{pH}$ is lowered; colloidal calcium phosphate dissociates from the micelles. At $\mathrm{pH} 5$ and below nearly all of the calcium and inorganic phosphorus is present in the serum (Dalgleish and Law; 1989; Law, 1996; Singh et al., 1996; van Hooydonk et al., 1986). This results in dissociation of a portion of all caseins from the micelles as the $\mathrm{pH}$ is lowered. The concentration of dissociated casein increases to a maximum at $\mathrm{pH} \sim 5.4$ and then decreases as $\mathrm{pH} 4.6$, the isoelectric point of casein, is approached (Dalgleish and Law, 1988; Law, 1996; Singh et al., 1996). As the isoelectric pH is approached, the degree of dissociation of the carboxylic groups at the hairs of $\kappa$-casein is diminished. Therefore the solvent quality for K-casein hairs decreases. Near the isoelectric $\mathrm{pH}$ the micelles aggregate. Aggregation may lead either to a coagulum consisting of separate, compact flocs, which usually sediment and form a precipitate, or to a gel in which the flocculated particles form a network that extends throughout the liquid. Casein micelles in milk usually form a gel on aggregation if the liquid is kept at rest, but when the liquid is stirred a precipitate forms (Walstra and Jenness, 1984). Several conditions affect the $\mathrm{pH}$ dependence of the properties of casein micelles and the structure of the gels at ambient temperatures and above: preheating the milk (Cobos et al., 1995; Heertje et al., 1985; Kim and Kinsella, 1989; Law ,1996; Lucey et al., 1997; Singh et al., 1996; Van Vliet and Keetels, 1995), addition of $\mathrm{CaCl}_{2}$ ( $\mathrm{Kim}$ and Kinsella, 1989) or some calcium chelating agents (Bloomfield and Morr, 1973; Johnston and Murphy, 1992) and concentration of casein micelles (Cobos et al., 1995).

Aggregation of casein micelles in milk in the cold has hardly been studied. The composition of the micelles at refrigeration temperatures was studied by Dalgleish and Law $(1988,1989)$. They observed that the amounts of salts dissociated as a function of $\mathrm{pH}$ did not 
vary significantly between 4 and $20^{\circ} \mathrm{C}$. However, the amount of dissociated caseins at $\mathrm{pH}$ values in the range from 6.8 to 4.9 was much larger at 4 than at $20^{\circ} \mathrm{C}$, especially the amount of $\beta$-casein. This can be explained by assuming that part of the $\beta$-casein is bound to micelles by hydrophobic bonds, which are weaker at lower temperatures. Roefs (1986) studied the casein micelle size distribution as a function of $\mathrm{pH}$ at $8^{\circ} \mathrm{C}$ and studied the structure of gels formed by heating milk, which was acidified at $0-2^{\circ} \mathrm{C}$ with $\mathrm{HCl}$ to $\mathrm{pH} 4.6$, at rest. $\mathrm{He}$ observed that casein micelles in milk acidified at $0-2^{\circ} \mathrm{C}$ with $\mathrm{HCl}$ to $\mathrm{pH} 4.6$ did not aggregate at temperatures below $10^{\circ} \mathrm{C}$. De Kruif and Roefs (1996) and Hammelehle et al. (1997) acidified milk in the cold to various $\mathrm{pH}$ and then heated the samples. They observed that the temperature of aggregation increased with increasing $\mathrm{pH}$. De Kruif and Roefs (1996) concluded that the origin of these phenomena resides probably in the change in stabilization of the micelles on cooling. At low temperatures $\beta$-casein seems to supplement the function of $\kappa$-casein in sterically stabilizing the casein micelle (Walstra, 1979). Hammelehle et al. (1997) showed that the relationship was different for various acidulants.

There is limited knowledge about the acid induced aggregation of casein micelles in the cold. Since many milk products are stored at low temperatures, it is important to understand the behaviour of casein micelles in the cold. The aim of this study was to study the influence of type of acidulant, the addition of salts, the influence of concentration of milk and preheat treatment on the aggregation of casein micelles in the cold. Preliminary results of this study were published in a short communication by Jonkman et al. (1999).

\subsection{Materials and Methods}

\subsubsection{Materials}

Reconstituted skim milk was prepared by dispersing $10.0 \mathrm{~g}$ of a commercial low-heat skim milk powder (Coberco, Lochem, the Netherlands) in $90.0 \mathrm{~g}$ demineralized water at room temperature. Reconstituted concentrated skim milk was made by dissolving $19.0 \mathrm{~g}$ of the skim milk powder in $81.0 \mathrm{~g}$ demineralized water. The influence of heat treatment (to cause denaturation of most serum proteins) was studied by heating the reconstituted skim milk for 30 minutes at $90^{\circ} \mathrm{C}$. To prevent bacterial growth, $0.015 \%$ of thiomersal (BDH Chemicals LTD) was added to the samples. To allow equilibration the samples were left for 48 hours at $3^{\circ} \mathrm{C}$.

Samples were acidified at $3^{\circ} \mathrm{C}$ in a cold room with glucono- $\delta$-lactone (GDL) or with $\mathrm{HCl}(37 \%)$. GDL is an acid precursor which slowly hydrolyses, forming gluconic acid. Gluconic acid is a weak acid, which further dissociates to gluconate ions and hydrogen ions. After addition of defined amounts of GDL, the samples were stirred for five minutes and then left at $3^{\circ} \mathrm{C}$ for 7 days. Several properties of a sample acidified with $1.2 \%$ GDL as a function 
of time after addition of GDL are shown in Figs. 7.1A and B. To study the effect of stirring, some samples acidified with GDL were continuously stirred for 7 days.
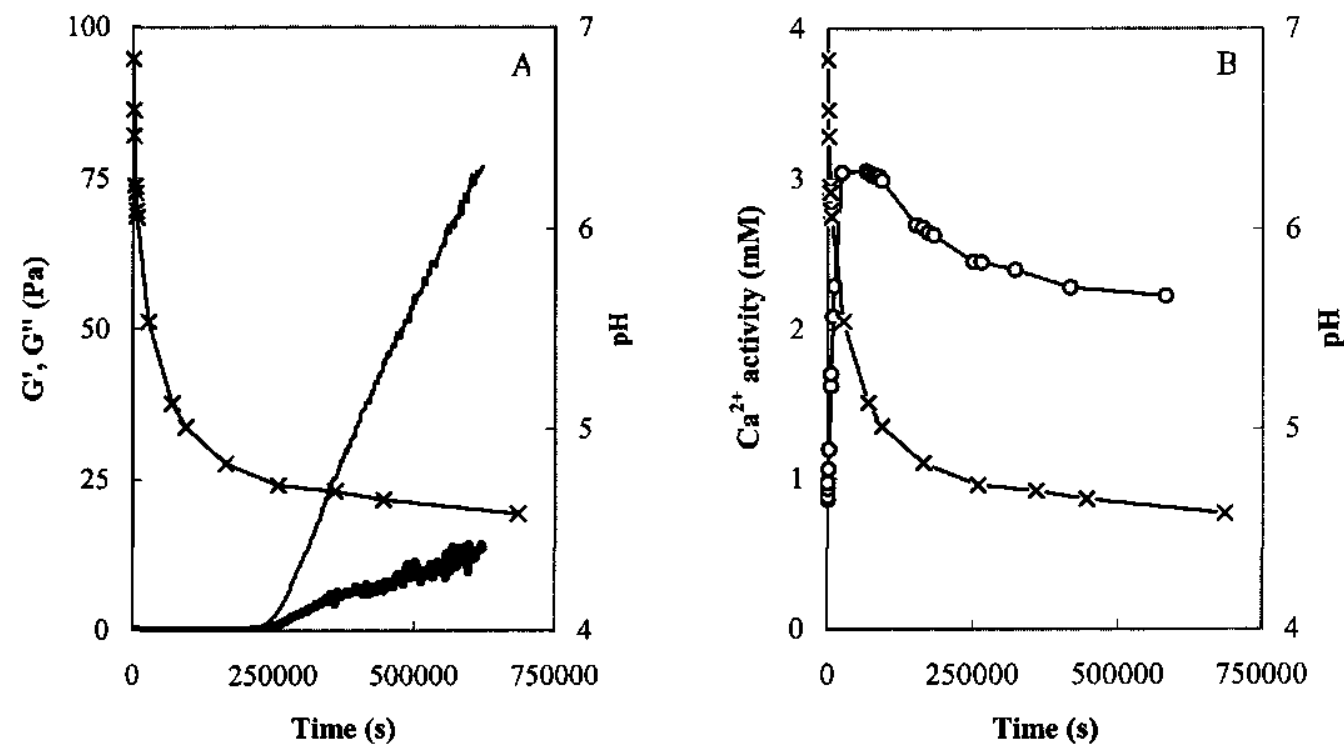

Fig. 7.1. Skim milk acidified with 1.2\% GDL at $3{ }^{\circ} \mathrm{C} .(A) \mathrm{pH}(x)$, storage $(-)$ and loss moduli (-) as a function of time after addition of $G D L .(B) p H(x)$ and calcium ion activity (o) as a function of time after addition of $G D L$.

Samples were acidified with $\mathrm{HCl}$ within five minutes to the desired $\mathrm{pH}$ while continuously stirring. After acidification samples were left for 7 days at $3^{\circ} \mathrm{C}$. To study the influence of acidification rate, some samples were slowly acidified with $\mathrm{HCl}$ in 7 days to $\mathrm{pH}$ 4.7. The $\mathrm{pH}$ as a function of time was then about the same as for a sample acidified with $1.2 \%$ GDL.

In one experiment reconstituted skim milk was acidified at $30^{\circ} \mathrm{C}$ in a waterbath with $\mathrm{HCl}(3 \mathrm{M}), \mathrm{GDL}$, acetic acid (3M), lactic acid (0.55M) or butyric acid (3M).

To observe the effect of various cations on aggregation of casein micelles in the cold, a calcium sequestrant (sodium citrate or EDTA), $\mathrm{CaCl}_{2}, \mathrm{MgCl}_{2}$ or $\mathrm{NaCl}$ was added to skim milk. Since these additives change the $\mathrm{pH}$ of skim milk, the $\mathrm{pH}$ was adjusted with $\mathrm{NaOH}$ or $\mathrm{HCl}$. The $\mathrm{pH}$ 's were not adjusted to the $\mathrm{pH}$ of the original skim milk, but to a $\mathrm{pH}$ that would result in the same $\mathrm{pH}$ after acidification as that of the sample to which no salt had been added. The necessary amounts of $\mathrm{NaOH}$ or $\mathrm{HCl}$ were determined in advance by measuring the $\mathrm{pH}$ of acidified samples to which salts had been added. After adjusting the $\mathrm{pH}$ the samples were acidified with $\mathrm{HCl}$ or GDL as described above. 


\subsubsection{Methods}

Most of the measurements were performed after 7 days storage at $3^{\circ} \mathrm{C}$. In some experiments the measurements were started after addition of $\mathrm{GDL}$ or $\mathrm{HCl}$ and were performed for 7 days. In one experiment measurements were performed after 48 hours at $30^{\circ} \mathrm{C}$.

The flocculation temperature was determined by heating skim milk in a thermostatted waterbath from $3^{\circ} \mathrm{C}$ until the temperature of visible flocculation. The temperature was raised at $0.2 \mathrm{~K}$ per minute.

Calcium ion activities and $\mathrm{pH}$ were measured at 3 or $30^{\circ} \mathrm{C}$. Details of the measurement of the calcium ion activity are given in chapter 4.2.4.

For the analysis of free proteins, the sample was partitioned into a pellet of micellar material and a serum fraction by centrifugation at $70000 \mathrm{~g}$ at $3^{\circ} \mathrm{C}$ during 4 hours. A Beckman XL-90 centrifuge with a S28 rotor was used for this purpose. After centrifugation the supernatant was poured off and used for analysis.

The nitrogen content was determined using the macro Kjeldahl method according to IDF Standard 20B:1993.

The appearance of casein micelles in acidified skim milk at $3^{\circ} \mathrm{C}$ was observed by freeze-fracture electron microscopy. The same procedure as described in section 4.2 .6 was used.

Firmness of the gels was measured with a Sur Berlin Penetrometer PNR 10 adjusted with a plexiglass cone 18-2361. The time of fall was $0.1 \mathrm{~s}$.

Dynamic rheological measurements were performed at $3^{\circ} \mathrm{C}$ using a Bohlin CVO Rheometer. The same instrumental settings during the measurements were applied as described in section 4.2.5.

The relationship between the storage modulus and the firmness of the samples acidified with GDL is shown in Fig. 7.2. It can be seen from Fig. 7.2 that a small difference in penetration depth (especially between 35 and $37 \mathrm{~mm}$ ) corresponds to a large relative difference in storage modulus. 


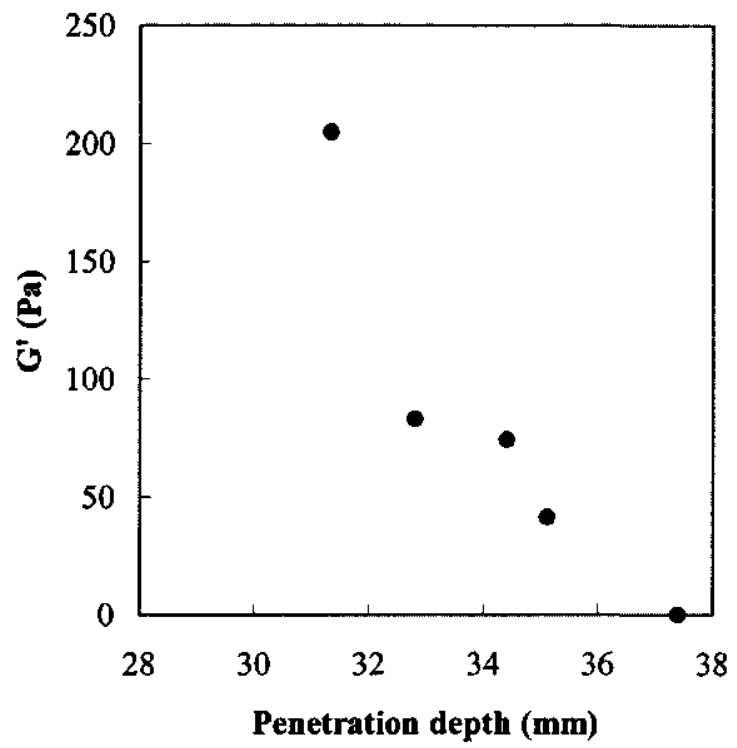

Fig. 7.2. Relation between storage modulus of and the penetration depth of a plexiglass cone in a skim milk gel obtained by acidification with GDL at $3^{\circ} \mathrm{C}$.

\subsection{Results and Discussion}

In various studies (De Kruif and Roefs, 1996; Hammelehle et al., 1997; Roefs, 1986) it was observed that casein micelles in skim milk acidified with $\mathrm{HCl}$, lactic or citric acid to $\mathrm{pH} 4.6$ at $3^{\circ} \mathrm{C}$ do not flocculate. In this study skim milk was acidified with $\mathrm{GDL}$ or $\mathrm{HCl}$ at $3^{\circ} \mathrm{C}$ to various $\mathrm{pH}$ values. Fig. 7.3 shows the firmness of skim milk samples acidified with GDL $(0.75-1.3 \%)$ and $\mathrm{HCl}$ after 7 days at $3^{\circ} \mathrm{C}$. Casein micelles in skim milk acidified with $\mathrm{HCl}$ did indeed not flocculate at $\mathrm{pH} 4.6$; however, casein micelles in skim milk acidified with GDL to $\mathrm{pH} 4.6$ aggregated and a gel was formed. The experiments showed that in skim milk acidified with $\mathrm{HCl}$ aggregates at $3^{\circ} \mathrm{C}$ were formed at $\mathrm{pH} 4.5$. In skim milk acidified with GDL to $\mathrm{pH}$ 4.8 and lower a gel was formed. Variation in $\mathrm{pH}$ of aggregation among acidulants was also observed by Hammelehle et al. (1997). They acidified pasteurized skim milk with $\mathrm{HCl}$, citric or lactic acid at $2^{\circ} \mathrm{C}$ and heated the samples next. The onset of gelation began at a lower $\mathrm{pH}$, if $\mathrm{HCl}$ was used for acidification rather than lactic or citric acid. The samples acidified with lactic or citric acid acidified to $\mathrm{pH} 4.6 \mathrm{did}$, however, not show aggregation at $3^{\circ} \mathrm{C}$. 


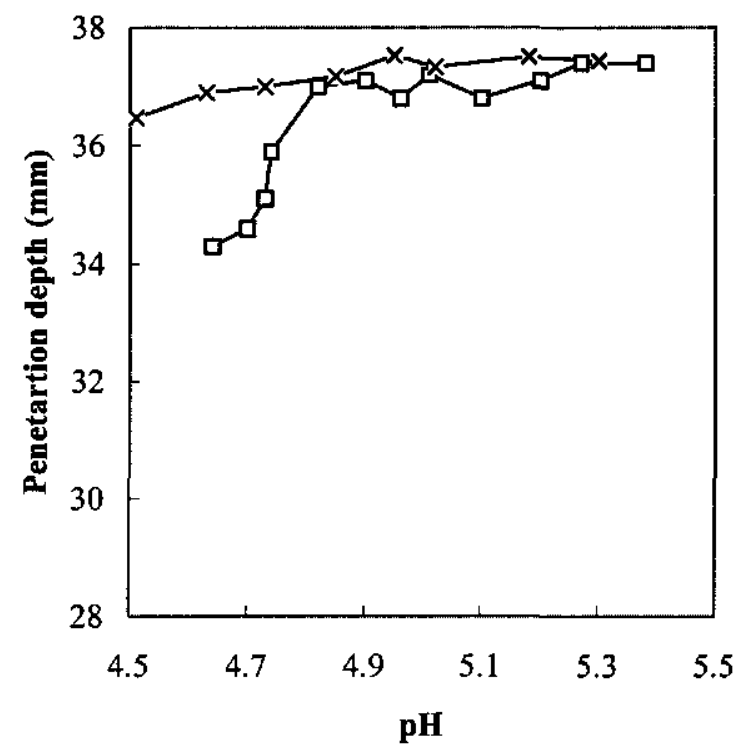

Fig. 7.3. Penetration depth of a plexiglass cone in skim milk acidified with GDL (0.75-1.3\%) $(D)$ or with $\mathrm{HCl}(X)$ after 7 days storage at $3^{\circ} \mathrm{C}$.

Electron micrographs of samples acidified with $\mathrm{HCl}$ and $\mathrm{GDL}$ at $\mathrm{pH}$ values between 5.08 and 4.67 supported the observed difference in $\mathrm{pH}$ of aggregation of the different acidification methods (Figs. 7.4A-D). On electronmicrographs of skim milk acidified with $\mathrm{HCl}$ to $\mathrm{pH} 5.08$ (Fig. 7.4A) and with $1.0 \%$ GDL to $\mathrm{pH} 4.92$ (Fig. 7.4B) many small micelles and submicelles could be observed. It was found (see Fig. 7.5) that about $30-55 \%$ of the casein at $\mathrm{pH}$ 4.9-5.1 was present in the serum. This implies that either many small micelles must have been present, or the micelles must have been very voluminous. The micrographs appear to support the first suggestion, which does not agree with measurements of the average diameter of casein micelles in skim milk at $8^{\circ} \mathrm{C}$ performed by Roefs (1986). His results suggest that the average diameter of casein micelles at $\mathrm{pH} 5$ at $8^{\circ} \mathrm{C}$ was about $275 \mathrm{~nm}$. The discrepancy between our micrographs and the light scattering data of Roefs may be due to a difference in temperature. The data of Roefs were obtained at $8^{\circ} \mathrm{C}$ and ours at $4^{\circ} \mathrm{C}$. At low temperatures, hydrophobic bonds are weaker. If the temperature is lowered, this would result in an increase in voluminosity of the casein micelles. At even lower temperatures it can possibly result in partial disintegration of micelles. On micrographs of skim milk acidified with $\mathrm{HCl}$ to $\mathrm{pH} 4.67$ (Fig. 7.4C) casein micelles can be observed. However, micrographs of skim milk acidified with $1.1 \%$ GDL ( $\mathrm{pH} 4.81$, Fig. 7.4D) show aggregates of casein micelles. 
A

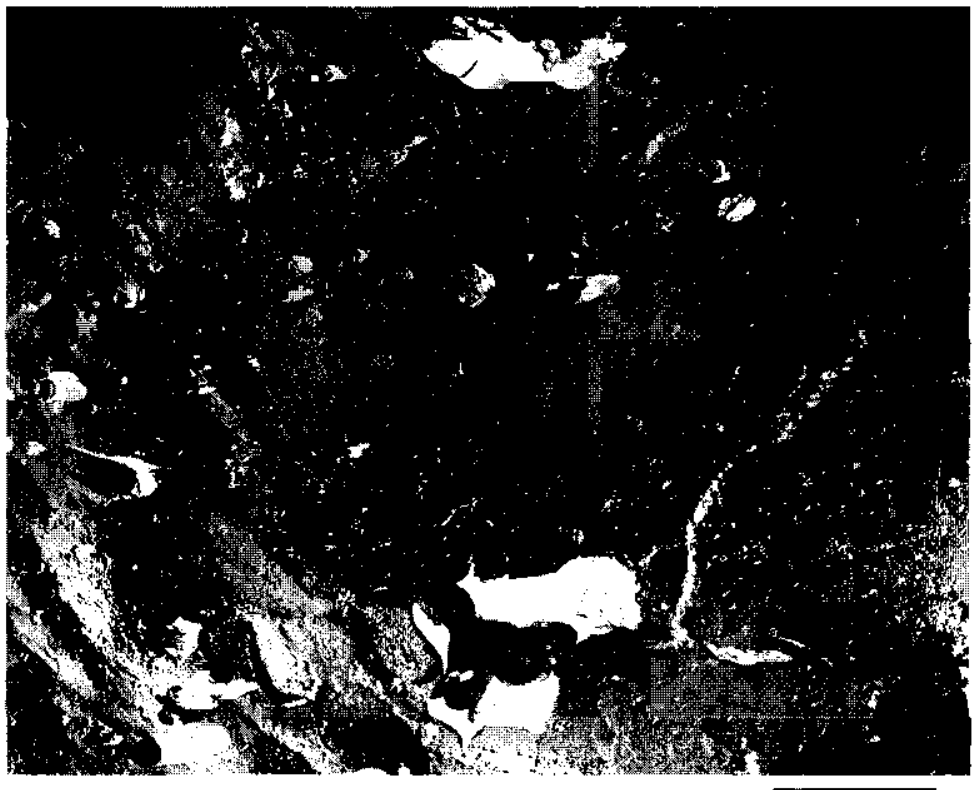

B

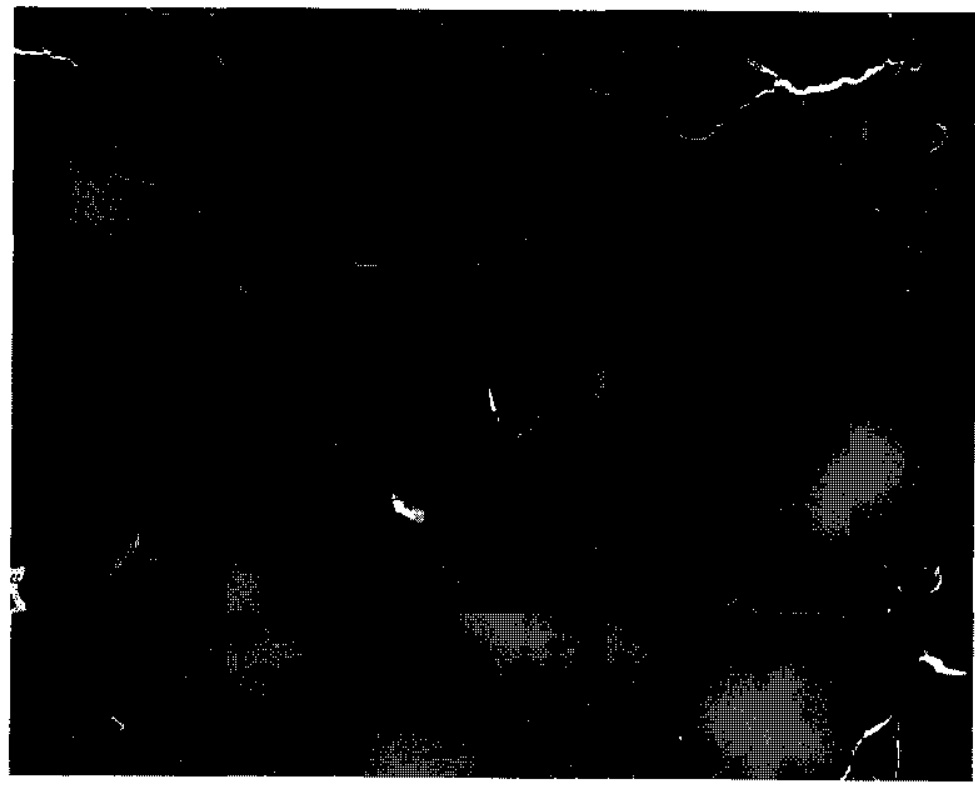

Fig. 7.4. Electron micrographs of acidified skim milk after 7 days of storage at $3^{\circ} \mathrm{C}$. (A) Skim milk acidified with $\mathrm{HCl}$ pH 5.08. (B) Skim milk acidified with 1.0\% GDL pH 4.92 (scale bar = $500 \mathrm{~nm})$. 
C

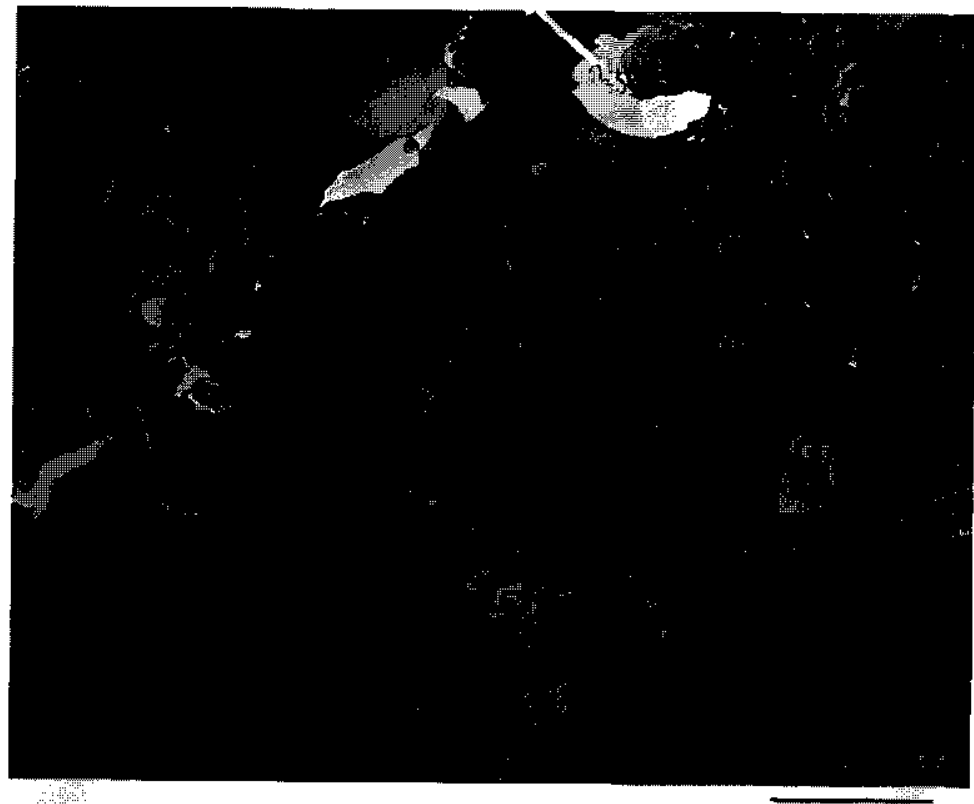

$\mathrm{D}$

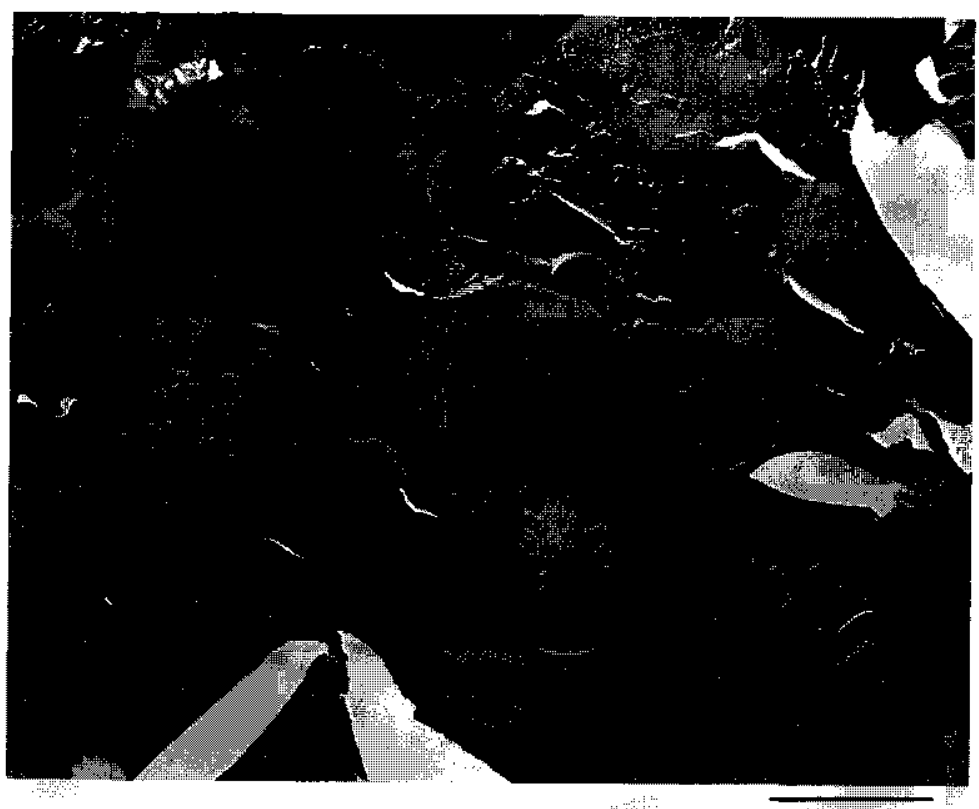

Fig. 7.4. Electron micrographs of acidified skim milk after 7 days of storage at $3^{\circ} \mathrm{C}$ (C) Skim milk acidified with $\mathrm{HCl}$ pH 4.67. (D) Skim milk acidified with 1.1\% GDL pH 4.81 (scale bar $=500 \mathrm{~nm}$. 
Three possible explanations were considered for the difference in $\mathrm{pH}$ of aggregation. The first explanation is that the difference was caused by the fact that samples acidified with $\mathrm{HCl}$ were stirred during acidification and samples with GDL not. Stirring would break any aggregates that are formed immediately. However, a sample that had been stirred during acidification with GDL for 7 days was clearly more viscous than a sample acidified with $\mathrm{HCl}$. Therefore this explanation was rejected.

A second explanation would be that samples acidified with GDL were acidified much slower than samples acidified with $\mathrm{HCl}$. The acidification rate could affect the dissociation of caseins and the structure of casein aggregates. In Fig. 7.5 the amount of casein present in the supernatant of skim milk acidified at $3^{\circ} \mathrm{C}$ is shown. From Fig. 7.5 it can be concluded that no difference in dissociation of caseins in skim milk acidified with $\mathrm{HCl}$ and GDL occurs. Dalgleish and Law (1988) also observed no difference between GDL and $\mathrm{HCl}$ in respect of the liberation of casein. The viscosity of a sample acidified with $\mathrm{HCl}$ to $\mathrm{pH} 4.7$ at the same rate as one acidified with $1.2 \%$ GDL, was the same as that of a sample acidified within 5 minutes and no aggregates were observed in the sample which was slowly acidified. Hammelehle et al. (1997) acidified all their samples at the same rate and they also observed variation in $\mathrm{pH}$ of aggregation among acidulants. Therefore, we concluded that the acidification rate did probably not affect the dissociation of caseins and the structure of casein aggregates.

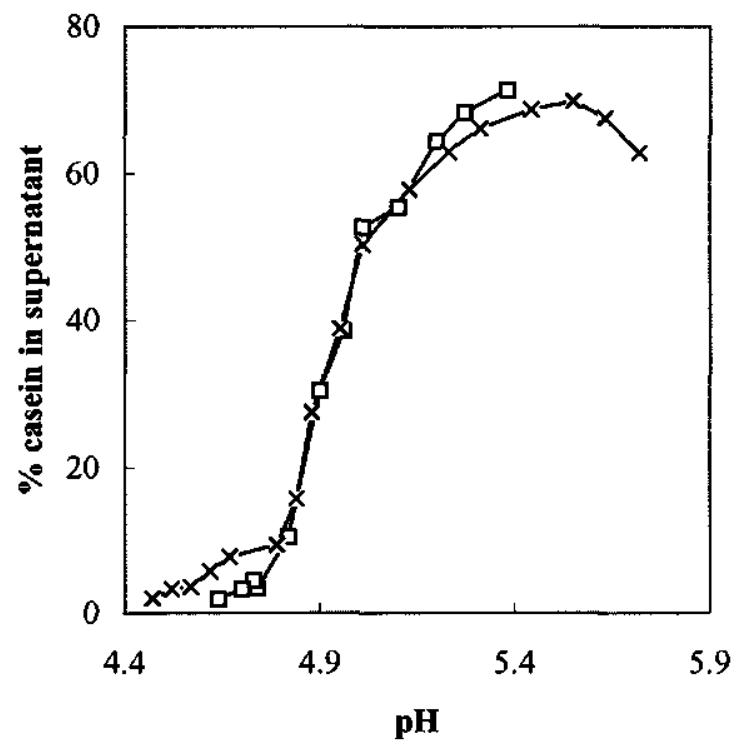

Fig. 7.5. Percentage of casein in supernatant of skim milk acidified with $\mathrm{GDL}(\square)$ and $\mathrm{HCl}$ (X) after 7 days at $3^{\circ} \mathrm{C}$. 
A third explanation for the difference in $\mathrm{pH}$ of aggregation is variation in the calcium ion activity of the acidified skim milk. Fig. 7.6 shows the calcium ion activity of skim milk acidified with $\mathrm{GDL}$ and $\mathrm{HCl}$ to different $\mathrm{pH}$ values. The calcium ion activity depends on the calcium ion concentration and the ionic strength. When the $\mathrm{pH}$ of milk is lowered, calcium phosphate dissociates from the micelle. As a result the calcium ion concentration and the ionic strength increase. An increase in the calcium ion concentration will result in an increase in calcium ion activity. An increase in ionic strength will lead to a decrease in activity coefficient and thereby to a decrease in calcium ion activity. From Fig. 7.6 it can be seen that skim milk acidified with $\mathrm{HCl}$ considerable increases in calcium ion activity. The effect of increase in calcium ion concentration must have been much stronger than the effect of increase in ionic strength. The calcium ion activity of skim milk at $\mathrm{pH} 4.8$ at $3^{\circ} \mathrm{C}$ can be estimated using the model for the ion equilibria in milk diffusate at $20^{\circ} \mathrm{C}$ developed by Holt $e t$ al. (1981). Assuming all of the calcium, inorganic phosphorus, magnesium and citrate to be present in milk serum at $\mathrm{pH} 4.8$, the ionic strength is calculated at $120 \mathrm{mM}$ and the calcium ion activity at $5.0 \mathrm{mM}$. Although the association constants in the model were determined at $20-25^{\circ} \mathrm{C}$, the calculated calcium ion activity corresponds well with the measured calcium ion activity of skim milk acidified with $\mathrm{HCl}$ to $\mathrm{pH} 4.8$ at $3^{\circ} \mathrm{C}$. Fig. 7.6 shows that the calcium ion activity of skim milk acidified with GDL is much lower than that of skim milk acidified with $\mathrm{HCl}$. Since calcium gluconate is used in foods as a sequestrant (Lindsay, 1996), we suppose that the lower calcium ion activity in skim milk acidified with GDL is in all probability due to association of calcium by gluconate ions. Assuming that the equilibrium constants for the equilibrium between GDL and gluconic acid and the acid dissociation constant are the same at 25 and $3^{\circ} \mathrm{C}$, at $3^{\circ} \mathrm{C}$ about $80 \%$ of GDL will hydrolyse to gluconic acid and the acid dissociation constant $\mathrm{pK}_{\mathrm{a}}$ is 3.85 (Mitchell and Duke, 1970). Using these data, the calculated concentration of gluconate ions in skim milk acidified with $1.2 \%$ GDL to $\mathrm{pH} 4.8$ is $51 \mathrm{mM}$. The difference between the calcium ion concentration in skim milk acidified with $\mathrm{HCl}$ and GDL can be used as an estimate for the number of calcium ions associated with gluconate ions. Assuming the ionic strength to be the same in skim milk acidified with $\mathrm{HCl}$ or GDL, the calcium ion concentration in skim milk acidified with GDL is $6.7 \mathrm{mM}$, the calcium ion concentration in skim milk acidified with $\mathrm{HCl}$ is $15 \mathrm{mM}$ and the estimated concentration of calcium ions associated with gluconate ions is $8.3 \mathrm{mM}$. If we assume that two moles of gluconate ions associate with one mole of calcium, then $16.5 \mathrm{mM}$ of gluconate ions would be associated with calcium ions. Assuming no association of gluconate ions with other cations the stability constant for calcium ions with gluconate ions $\log \mathrm{K}$ is 1.6. For a sequestrant this is a fairly small stability constant. However, gluconate ions may not only associate with calcium ions, but also with other cations. 


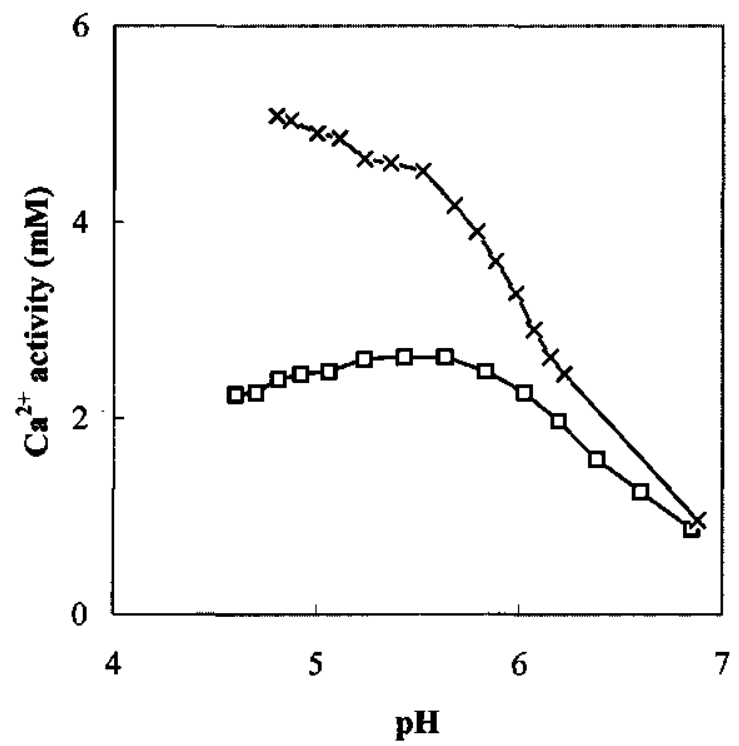

Fig. 7.6. Calcium ion activity of skim milk acidified with $\mathrm{GDL}(0-1.3 \%)(\square)$ and $\mathrm{HCl}(\mathrm{X})$ after 7 days of storage at $3^{\circ} \mathrm{C}$.

The calcium ion activity of skim milk acidified with various acidulants was also determined at $30^{\circ} \mathrm{C}$. As can be seen from the results in Table 7.1 , gluconate ions do not only associate with calcium ions at $5^{\circ} \mathrm{C}$, but also at $30^{\circ} \mathrm{C}$. Besides gluconate ions also lactic acid and butyric acid appear to associate with calcium ions. It is known that any molecule or ion with an unshared electron pair can coordinate or form complexes with metal ions. Therefore, compounds containing two or more functional groups, such as $-\mathrm{OH}$, and $-\mathrm{COOH}$, in proper geometrical relation to each other, can chelate metals in a favorable physical environment (Lindsay, 1996). Our hypothesis is that two conjugate base molecules of the acid associate with one calcium ion and that the acid needs to have a $-\mathrm{COOH}$ group and an adjacent $-\mathrm{OH}$ group. The presumable configuration resembles that of association of calcium with EDTA. However, applying this hypothesis, butyric acid would not associate with calcium ions. We cannot explain why skim milk acidified with butyric acid also has a low calcium ion activity. When we compare the calcium ion activity of skim milk acidified with GDL or $\mathrm{HCl}$ at $30^{\circ} \mathrm{C}$ (see Table 7.1 ) to $3^{\circ} \mathrm{C}$ (see Fig. 7.6), the calcium ion activity is higher at $30^{\circ} \mathrm{C}$ than at $3^{\circ} \mathrm{C}$. This is in all probability due to the dependence of the association constants of the salts on temperature. The calcium ion activity of skim milk acidified with $\mathrm{HCl}$ at $30^{\circ} \mathrm{C}$ is higher than the calcium ion activity calculated above using the model for the ion equilibria in milk diffusate at $20^{\circ} \mathrm{C}$ developed by Holt et al. (1981). This may also be due to the difference in temperature. 
Table 7.1. Calcium ion activity of skim milk acidified with various acidulants after 48 hours at $30^{\circ} \mathrm{C}$.

\begin{tabular}{lll}
\hline & $\mathrm{aCa}^{2+}(\mathrm{mM})$ & $\mathrm{pH}$ \\
\hline $\mathrm{HCl}$ & 6.64 & 4.89 \\
Acetic acid & 6.15 & 4.87 \\
Lactic acid & 4.56 & 4.98 \\
Butyric acid & 4.33 & 4.94 \\
$1.1 \%$ GDL & 3.38 & 4.70 \\
\hline
\end{tabular}

If the calcium ion activity is of importance for the aggregation of casein micelles in the cold, then an increase in calcium ion activity of the samples prior to acidification with GDL would result in a decrease in aggregation of casein micelles after acidification with GDL and in firmness of the gels obtained. Fig. 7.7 shows that when the calcium ion activity of samples acidified with $1.2 \%$ GDL is increased by addition of $\mathrm{CaCl}_{2}$ the firmness of the gels markedly decreased. This is in contrast to the effect observed at higher temperatures. Kim and Kinsella (1989) showed that a firmer gel was obtained when $\mathrm{CaCl}_{2}$ was added to skim milk prior to acidification with GDL at $50^{\circ} \mathrm{C}$. It can also be seen from Fig. 7.7 that when the calcium ion activity was decreased by addition of sodium citrate to below $1.8 \mathrm{mM}$, the firmness of gels did not increase any further. A decrease in calcium ion activity by addition of $0.02 \mathrm{~mol}$ EDTA $/ \mathrm{kg}$ prior to acidification with $\mathrm{HCl}$ to $\mathrm{pH} 4.9$ in the cold led to formation of visible aggregates. On electron micrographs, aggregates of micelles could also be observed (Fig. 7.8). 


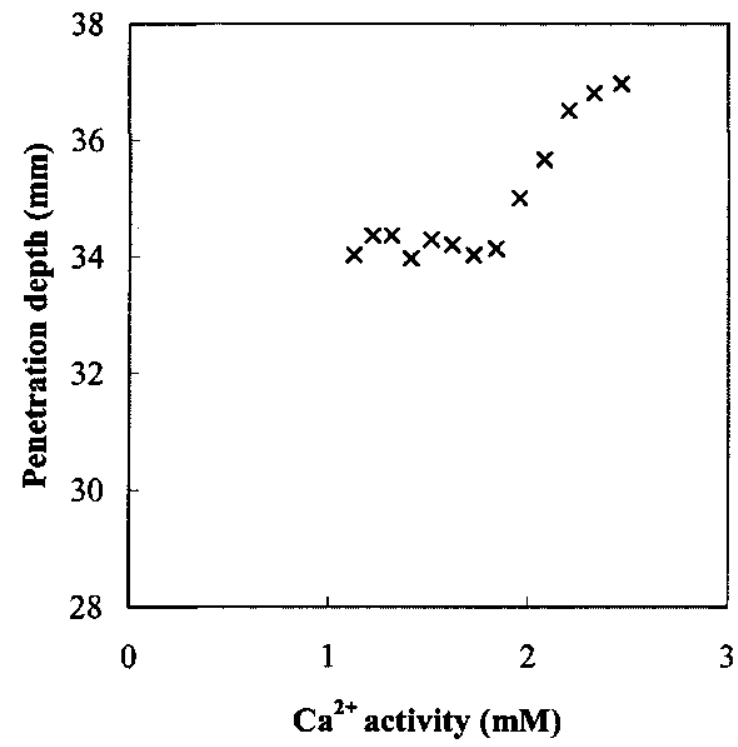

Fig. 7.7. Influence of calcium ion activity on the penetration depth of a plexiglass cone in skim milk acidified with $1.2 \%$ GDL after 7 days storage at $3^{\circ} \mathrm{C}$. The calcium ion activity was adjusted by addition of sodium citrate $(0.002-0.014 \mathrm{M})$ or $\mathrm{CaCl}_{2}(0.002-0.012 \mathrm{M})$ prior to acidification. The pH of the samples varied between 4.70 and 4.73 .

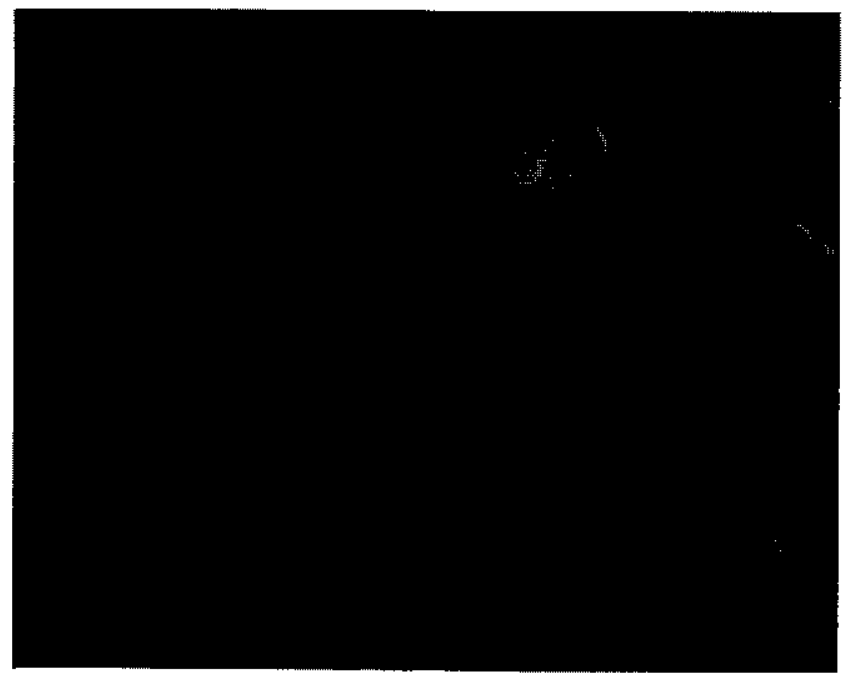

Fig. 7.8. Electron micrograph of skim milk acidified with $\mathrm{HCl}$ to $\mathrm{pH} 4.9$ after 7 days of storage at $3^{\circ} \mathrm{C}$. To the milk $0.02 \mathrm{~mol}$ EDTA/kg was added prior to acidification (scale bar = $500 \mathrm{~nm})$. 
The influence of salts on the aggregation of casein micelles can also be studied by the effect on the flocculation temperature. Skim milk to which various amounts of $\mathrm{CaCl}_{2}(0-0.030$ $\mathrm{mol} / \mathrm{kg}$ ) had been added was acidified with $\mathrm{HCl}$ to various $\mathrm{pH}$ values at $3^{\circ} \mathrm{C}$ and then heated. The temperature of flocculation is shown in Fig. 7.9. It can be seen from Fig. 7.9 that the temperature of flocculation increased with increasing $\mathrm{pH}$. This was also observed by De Kruif and Roefs (1996) and Hammelehle et al. (1997). De Kruif and Roefs explained this behaviour by applying a scaling relation for the collapse of the hairy layer ("brush"). The transition from a swollen brush to a collapsed state would be specified by the following scaling relation:

$$
\alpha^{2} \sigma=\text { constant }
$$

in which $\alpha$ is the charge density (degree of dissociation of carboxylic acid groups) and $\sigma$ the chain density of the brush on the surface of the micelle. A reduction in $\alpha$ (i.e. the $\mathrm{pH}$ ) is equivalent to a reduction in chain density. Both induce a collapse of the brush. They assumed that when temperature is reduced the brush density of casein micelles increases by $\beta$-casein dissociation. The increase in brush density shifts the onset of brush collapse to lower $\mathrm{pH}$ values. From Fig. 7.9 it can also be seen that the temperature of flocculation at the same $\mathrm{pH}$ increases with increasing calcium concentration. This also indicates that calcium influences the collapse of the brush, either by changing the charge density of the brush or by modifying the hairs of the brush. Although it is assumed that on increasing the temperature the amount of $\beta$-casein in the brush diminishes or even become absent from the brush, it can be seen from Fig. 7.9 that the effect of calcium is approximately the same for low and high temperatures. This implies that the effect of calcium is not restricted to the presence of $\beta$-casein or that the relaxation of $\beta$-casein from the brush to the micellar core could not take place during the time scale of the experiment. 


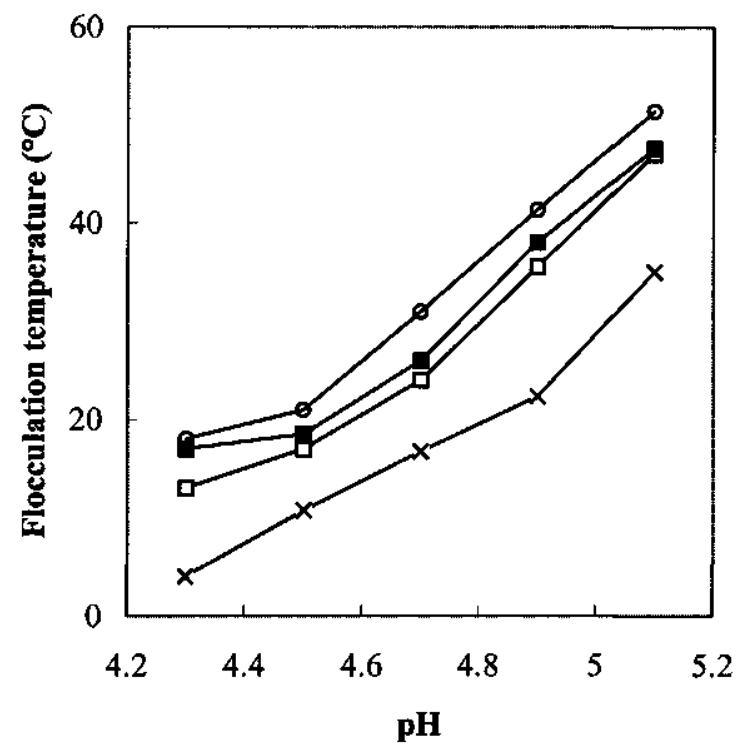

Fig 7.9. Influence of addition of $\mathrm{CaCl}_{2}$ (no addition (X), $0.010 \mathrm{~mol} \mathrm{CaCl}_{2} / \mathrm{kg}(\square), 0.020 \mathrm{~mol}$ $\mathrm{CaCl}_{2} / \mathrm{kg}(\mathrm{L}), 0.030 \mathrm{~mol} \mathrm{CaCl}_{2} / \mathrm{kg}(\mathrm{o})$ ) on temperature at which visible flocculation occurred in skim milk acidified to various $\mathrm{pH}$ values with $\mathrm{HCl}$.

As suggested above, besides calcium also other cations may associate with gluconate ions. From Fig. 7.10 it can be seen that the addition of $\mathrm{MgCl}_{2}$ had also a clear influence on the firmness of skim milk acidified with $1.2 \% \mathrm{GDL}$. The effect of $\mathrm{Mg}^{2+}$ was less than the effect of $\mathrm{Ca}^{2+}$. This was probably due to the slightly higher $\mathrm{pH}$ of the samples to which $\mathrm{CaCl}_{2}$ had been added. Addition of $\mathrm{NaCl}$, however, had little influence on the firmness of gels acidified with $1.2 \%$ GDL. Therefore, it was concluded that especially divalent cations decrease the firmness of gels made by cold acidification. 


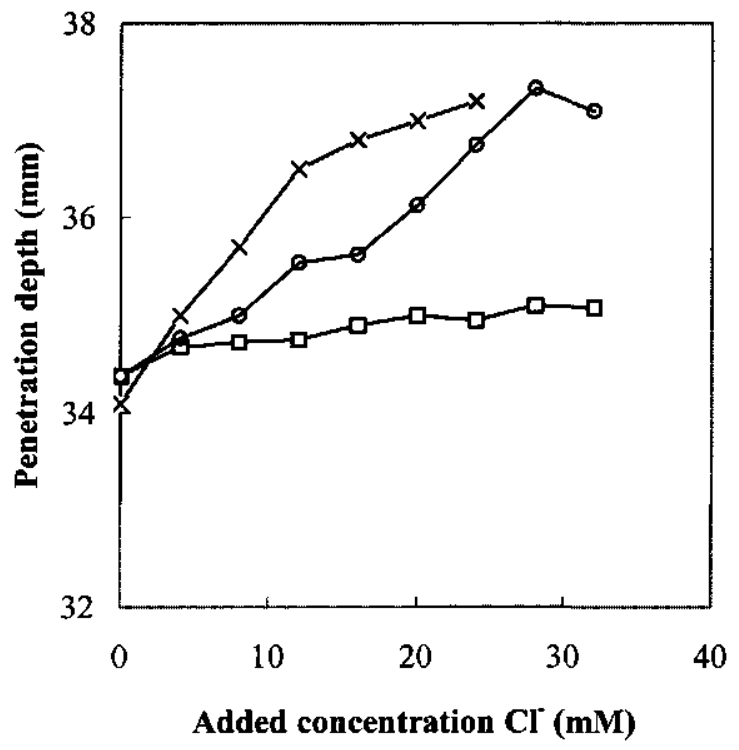

Fig. 7.10. Influence of addition of salts $\left(0.004-0.032 \mathrm{M} \mathrm{NaCl}(\mathrm{D}), 0.002-0.012 \mathrm{M} \mathrm{CaCl}_{2}(x)\right.$, $0.002-0.016 \mathrm{M} \mathrm{MgCl}_{2}$ (o)) on the penetration depth of a plexiglass cone in skim milk acidified with $1.2 \%$ GDL after 7 days storage at $3{ }^{\circ} \mathrm{C}$. The $\mathrm{pH}$ of the samples varied between 4.69 and 4.73 .

The influence of a preheat treatment on acidification of the skim milk in the cold was also studied. In heated samples a gel was already formed at a higher $\mathrm{pH}$ and around $\mathrm{pH} 4.7$ the gels were markedly firmer (Fig. 7.11). This was also found for milk acidified at room temperature (e.g. Cobos et al., 1995; Kim and Kinsella, 1989; Heertje et al., 1985). A possible explanation could be that after high heat treatment, the reaction of $\kappa$-casein with whey proteins diminishes its capacity to stabilize casein micelles, allowing these particles to coagulate at a higher $\mathrm{pH}$. Another explanation could be that as a result of association of denatured whey proteins with casein micelles the volume fraction of particles susceptible to aggregation increases and hence the $\mathrm{pH}$ at which flocculation occurs increases. Considering the results described in the next paragraph, this is, however, less likely. Van Vliet and Keetels (1995) supposed that the differences between the properties of gels acidified with GDL at $30^{\circ} \mathrm{C}$ to $\mathrm{pH} 4.6$ made from low and high heat skim milk stem from a difference in the way the casein aggregates were linked together, namely by straight or by bent (low-heat GDL gels) strands. To see whether this hypothesis can also be used to explain the influence of preheat treatment on the firmness of the gels at $\mathrm{pH} 4.7$ in our study, some more experiments (e.g. rheology, permeability) should be done. From Figs. 7.11 and 7.12 it can be seen that the effect 
of type of acidulant and of addition of divalent cations observed in unheated skim milk was the same in preheated skim milk.

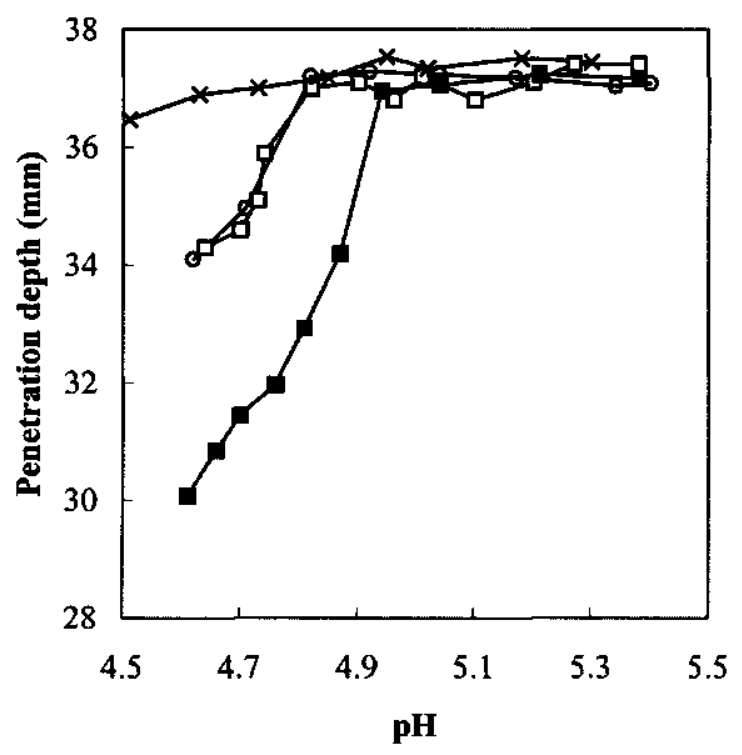

Fig. 7.11. Influence of heat treatment on the penetration depth of a plexiglass cone in skim milk acidified with GDL (not preheated $0.75-1.3 \%(\square)$, preheated $0.7-1.3 \%(\square)$ or with $\mathrm{HCl}$ (not preheated $X$, preheated o) after 7 days storage at $3^{\circ} \mathrm{C}$. 


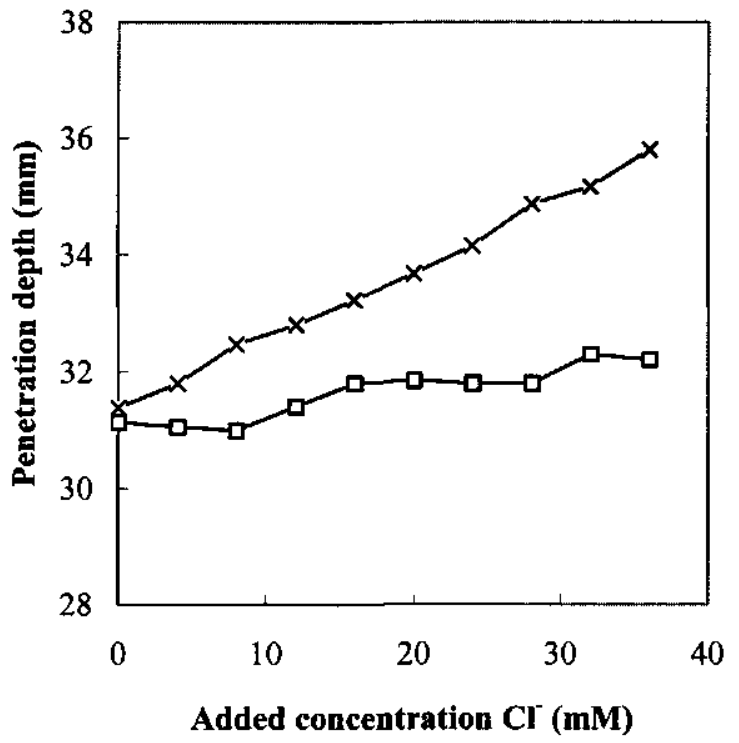

Fig. 7.12. Influence of addition of salts $(0.002-0.018 \mathrm{M} \mathrm{CaCl}(X)$ and $0.004-0.036 \mathrm{M} \mathrm{NaCl}$ (D) on the penetration depth of a plexiglass cone in preheated skim milk, acidified with $1.2 \%$ $G D L$, after 7 days storage at $3^{\circ} \mathrm{C}$. The $p H$ of the samples varied between 4.70 and 4.74 .

In Fig. 7.13 the influence of concentration of skim milk on the firmness of gels made by acidification of skim milk with GDL in the cold is shown. As a result of concentrating, the volume fraction of casein and the ionic strength were increased. The calcium ion activity was also slightly increased as a result of concentration (by $0.12-0.23 \mathrm{mM}$ ). It can be seen that the $\mathrm{pH}$ of gelation is not influenced by concentration. Cobos et al. (1995) also observed no effect on gelation $\mathrm{pH}$. The firmness of gels of concentrated skim milk at a certain $\mathrm{pH}$ was higher than gels made from skim milk. This is in all probability due to the increase in volume fraction of aggregated particles in concentrated skim milk. 


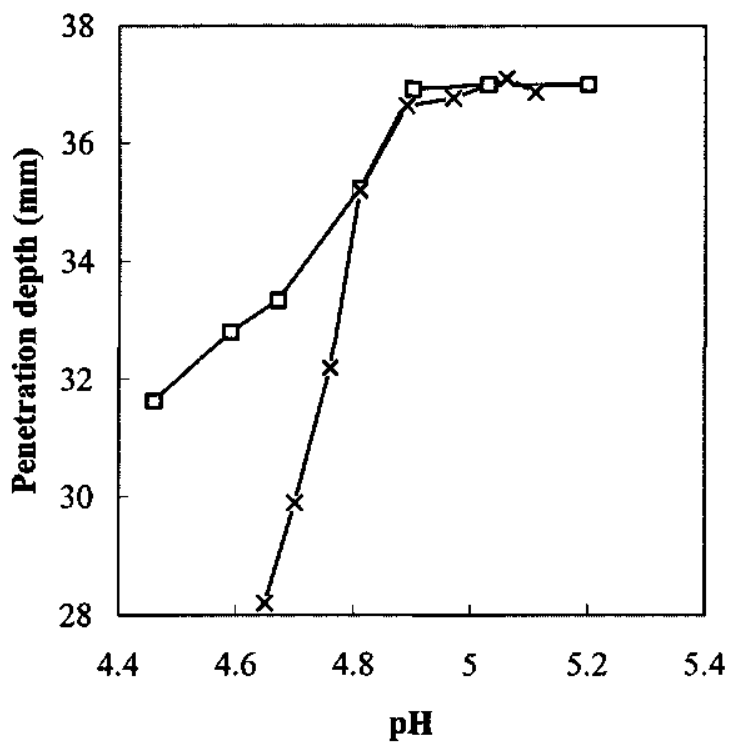

Fig. 7.13. Influence of concentration of skim milk on the penetration depth of a plexiglass cone in skim milk (D) and concentrated skim milk (19\% total solids) $(X)$ acidified with GDL after 7 days of storage at $3^{\circ} \mathrm{C}$.

The results described in this paper demonstrate that divalent cations play an important role in counteracting aggregation of casein micelles in the cold. Two possible mechanisms were considered by us. The first hypothesis is that a high divalent cation concentration could prevent the hairy layer, which sterically stabilizes the micelles, against collapse, possibly by crosslinking protruding peptide chains. A second explanation might be that charge inversion occurs. However, this explanation is less likely, since in that case it would be expected that samples acidified with $\mathrm{HCl}$ aggregate at a higher $\mathrm{pH}$.

\subsection{Conclusions}

The aggregation of micellar casein in skim milk in the cold is strongly influenced by the activity of divalent cations. At $\mathrm{pH} 4.7$ at $3^{\circ} \mathrm{C}$ casein micelles aggregate if the calcium ion activity is $2.5 \mathrm{mM}$ or lower. At higher calcium ion activities the casein micelles appear stable against aggregation. By varying the calcium ion activity of skim milk, the $\mathrm{pH}$ and temperature of aggregation in the cold can be changed. The $\mathrm{pH}$ of aggregation in the cold varies among acidulant types. This can be explained by the differences in association of the acidulants with divalent cations. The extent of association of divalent cations with various types of acidulants 
will not only be important for the $\mathrm{pH}$ of aggregation in the cold, but also for the choice of an acidulant in other processes in which skim milk is acidified and the calcium ion activity plays an important role (e.g. renneting of milk).

\section{Acknowledgements}

The authors thank Jan van Iersel and the then students Ingrid Muis, Hans Voogt and Martijn de Vries for performing preliminary experiments, and Mrs J. Brigham (Unilever Research Colworth Laboratory) for making electron micrographs.

\section{References}

Bloomfield, V.A. and Morr, C.V. (1973) Structure of casein micelles: physical methods. Netherlands Milk and Dairy Journal 27, 103-120.

Cobos, A., Horne, D.S. and Muir, D.D. (1995) Rheological properties of acid milk gels. 1. Effect of composition, process and acidification conditions on products from recombined milks. Milchwissenschaft 50, 444-447.

Dalgleish, D.G. and Law, A.J.R. (1988) pH-induced dissociation of bovine casein micelles. 1. Analysis of liberated caseins. Journal of Dairy Research 55, 529-538.

Dalgleish, D.G. and Law, A.J.R. (1989) $\mathrm{pH}$-induced dissociation of bovine casein micelles. 2. Mineral solubilization and its relation to casein release. Journal of Dairy Research 56, 727-735.

De Kruif, C.G. and Roefs, S.P.M.F. (1996) Skim milk acidification at low temperatures: A model for the stability of casein micelles. Netherlands Milk and Dairy Journal 50, 113-120.

Hammelehle, B., Schkoda, P. and Kessler, H.G. (1997) Parameters for coagulation properties of direct acidified milk and for the structure of milk gels. Milchwissenschaft 52, 671-674.

Heertje, I., Visser, J. and Smits, P. (1985) Structure formation in acid milk gels. Food Microstructure 4, 267 277.

Holt, C., Dalgleish D.G. and Jenness, R. (1981) Calculation of the ion equilibria in milk diffusate and comparison with experiment. Analytical Chemistry 113, 154-163.

Johnston, D.E. and Murphy, R.J. (1992) Effects of some calcium-chelating agents on the physical properties of acid-set milk gels. Journal of Dairy Research 59, 197-208.

Jonkman, M.J., Vliet, T. van, Walstra, P. and Cebula, D.J. (1999) Influence of calcium ion activity on aggregation of casein micelles at $\mathrm{pH} 5$ in the cold. International Dairy Journal 9, 387-388.

Kim, B.Y. and Kinsella, J.E. (1989) Rheological changes during slow acid induced gelation of milk by dglucono- $\delta$-lactone. Journal of Food Science 54, 894-898.

Law, A.J.R. (1996) Effects of heat treatment and acidification on the dissociation of bovine casein micelles. Journal of Dairy Research 63, 35-48. 
Lindsay, R.C. (1996) Food additives. In Food chemistry, ed. O.R. Fennema. Marcel Dekker Inc., New York, p 818.

Lucey, J.A., Tet Teo, C., Munro, P.A. and Singh, H. (1997) Rheological properties at small (dynarnic) and large (yield) deformations of acid gels made from heated milk. Journal of Dairy Research 64, 591-600.

Mitchell, R.E. and Duke, F.R. (1970) Kinetics and equilibrium constants of the gluconic acid-gluconate sytem. Annals New York Academy of Sciences 172, 131-141.

Roefs, S.P.F.M. (1986) Structure of acid casein gels; a study of gels formed after acidification in the cold. Ph.D. Thesis Wageningen Agricultural University, the Netherlands.

Singh, H., Roberts, M.S., Munro, P.A. and Tet Teo, C. (1996) Acid-induced dissociation of casein micelles in milk: Effects of heat treatment. Journal of Dairy Science 79, 1340-1346.

Thompson, M.P. and Farrell, H.M. (1973) The casein micelle - the forces contributing to its integrity. Netherlands Milk and Dairy Journal 27, 220-239.

Van Hooydonk, A.C.M., Boerrigter, J.J. and Hagedoorn, H.G. (1986) pH-induced physico-chemical changes of casein micelles in milk and their effect on renneting of milk. 2. Effect of $\mathrm{pH}$ on renneting of milk. Netherlands Milk and Dairy Journal 40, 297-313.

Van Vliet, T. and Keetels, C.J.A.M.. (1995). Effect of preheating of milk on structure of acidified milk gels. Netherlands Milk and Dairy Journal 49, 27-35.

Walstra, P. (1979) The voluminosity of bovine casein micelles and some of its implications. Journal of Dairy Research 46, 317-323.

Walstra, P. and Jenness, R. (1984) Dairy Chemistry and Physics. John Wiley \& Sons, New York.

Walstra, P. (1990) On the stability of casein micelles. Journal of Dairy Science 73, 1965-1979. 


\section{Summary}

Some of the physical properties of ice cream are essential quality marks. These properties are mainly determined by the processing and the ingredients. From a scientific and technological point of view, ice cream is a complicated product; during manufacture several different unit operations are applied, various types of ingredients are used and the resulting product has a complex structure. Unit operations applied include: mixing, pasteurising, homogenising, ageing (= storage at refrigeration temperatures for several hours), freezing and aeration, packaging, hardening (= storage at very low temperatures e.g. $-30^{\circ} \mathrm{C}$ ), and storage. As a general term of reference, ice cream may contain by volume $50 \%$ of air and by weight $10 \%$ fat, $11 \%$ solids-not-fat from milk, $15 \%$ added sugar, a few tenths of a per cent stabilizer and emulsifier, and $63.5 \%$ water (for the most part frozen). Ice cream is a frozen emulsion as well as a foam dispersed in a concentrated sweetened phase to which polysaccharides have been added. This phase is called ice cream plasma.

The plasma of ice cream is generally derived from milk and then contains milk proteins. About $80 \%$ of the milk protein is casein. In milk, casein occurs in colloidal aggregates, called casein micelles. The diameter of these particles is $50-300 \mathrm{~nm}$. The casein micelle is a complicated particle, made up of various proteins (caseins), minerals (micellar calcium phosphate and counterions) and water. The undissolved micellar calcium phosphate exchanges with dissolved calcium and phosphate in the serum. The behaviour of casein micelles is important for the properties of many dairy products and is fairly well known for conditions as in milk. However, much less is known and understood for conditions as are prevalent in ice cream. It is thought that the casein in ice cream plays a number of roles, of which the most important ones may be acting as an emulsifier during homogenization and as a foaming agent during the freezing process. It is known that caseins in ice cream are present in three locations: at the fat-plasma interface, at the air-plasma interface and in the plasma. The properties of casein micelles in ice cream cannot be predicted from the knowledge of the effects of processing and conditions on the behaviour of casein in milk. The state of the casein may be of importance for the physical properties of ice cream. The work presented in this thesis aims at determining and understanding the behaviour of casein micelles in the plasma phase of ice cream.

First a model ice cream plasma was developed. The processing was done in such a way that it resembles normal ice cream processing as close as possible. Since we studied ice cream plasma, neither fat nor air were added. Also no stabilizers were added. From a practical point of view it was not possible to perform the experiments at $-18^{\circ} \mathrm{C}$. Therefore a temperature of $-10^{\circ} \mathrm{C}$ was chosen. After ageing the model ice cream mix for 1 night at $5^{\circ} \mathrm{C}$, it was frozen without aeration in a scraped surface heat exchanger and stored at $-10^{\circ} \mathrm{C}$. Plasma was pressed from the ice cream in a special press. The composition of this plasma was 
broadly: water $42.3 \%$, sucrose $38.4 \%$, lactose $4.6 \%$, casein $8.4 \%$, calcium $0.37 \%$ and phosphorus $0.31 \%$.

The distribution of salts over micelles and serum, the casein micelle size distribution, and the micelle voluminosity, were determined in ice cream plasma at $-10^{\circ} \mathrm{C}$. The serum was obtained by ultrafiltration of ice cream plasma. The micelle size distribution was derived from electron micrographs. The voluminosity of the casein micelle was determined by viscometry.

In the first part of this work, the behaviour of casein micelles in ice cream plasma was determined. It was observed that structure and composition of casein micelles in ice cream plasma at $-10^{\circ} \mathrm{C}$ did not differ greatly from those of casein micelles in milk. A slightly increased amount of salts was associated with the micelles in ice cream plasma. The micellar calcium to inorganic phosphate ratio in ice cream plasma was about the same as in milk. Electron microscopy showed that casein in ice cream plasma exists in the form of micelles and submicelles. However, compared to milk, fewer submicelles and small micelles were present. Since the voluminosity was about the same as in milk (about $4.0 \mathrm{ml} / \mathrm{g}$ ), it was concluded that the increase in micelle size was primarily caused by fusion of micelles and not by swelling. The $\mathrm{pH}$ and calcium ion activity at room temperature are lower than those in milk. Most of the properties of the casein micelles in ice cream plasma may be explained by a combination of the two conditions which differ significantly as compared to milk: a high concentration of milk components and of sucrose, and a low temperature. The effect of concentration on the micelle properties appears to be slightly stronger than, and opposite to, the effect of a decrease in temperature. Concentration of milk results, for instance, in an increase in micellar calcium phosphate. However a decrease in temperature of milk causes some dissociation of calcium phosphate from the micelle. If ice cream plasma is stored at room temperature, only the concentration effect is of importance. As expected, warming of ice cream plasma to room temperature caused a decrease in the percentages of salts present in the serum.

During processing of ice cream, the mix is usually pasteurised. In the second part of this study the influence of heating on the structure and behaviour of casein micelles in ice cream plasma was studied. The ice cream mix was preheated for 30 minutes at $90^{\circ} \mathrm{C}$. After this heat treatment all of the serum protein was denatured. It was observed while heating at a lower intensity $\left(30 \mathrm{~min}\right.$ at $74^{\circ} \mathrm{C}$ ) that denaturation of serum protein proceeded slower in ice cream plasma than in milk. The percentage of calcium and phosphate in the serum and the voluminosity of the casein micelles were not influenced by preheating. In ice cream plasma made from unheated milk the number average micelle diameter was smaller and the volumesurface average diameter was larger than in ice cream made from low heat milk. The increase in number average diameter may be due to formation during heating of whey protein aggregates, or of whey protein-casein complexes, or of small casein particles. Another possibility is that fusion of micelles during concentration was hindered by heat-induced association of whey proteins with casein micelles. The increase in volume-surface diameter 
could be a result of an increase in micelle size due to association of denatured whey proteins and/or heat coagulation. Studies on the effect of heating and concentration on casein micelle size in skim milk solutions did not lead to conclusions about the mechanism involved.

Frozen yoghurt is a well known type of ice cream. The $\mathrm{pH}$ of frozen yoghurt is rather low. In milk a decrease in $\mathrm{pH}$ results in dissolution of calcium phosphate from the micelle and generally in the aggregation of casein. To study the behaviour of casein micelles in frozen yoghurt plasma, the $\mathrm{pH}$ of the ice cream mix was lowered to $\mathrm{pH} 4.0$ by addition of lactic acid. It was observed that nearly all of the calcium and inorganic phosphorus was present in the serum of the frozen yoghurt plasma. Frozen yoghurt plasma formed a gel during storage, suggesting a network of casein to be present. On electron micrographs aggregates of casein particles could be seen. After 10 months storage cracks in the gel were observed and the rheological properties had changed too. In all probability these changes were due to very slow rearrangements in the casein particle network.

Since some interesting phenomena were observed on acidification of ice cream mix in the cold, aggregation of casein micelles at low temperatures was studied in more detail in the last part of this work. Not ice cream mix, but milk was chosen as the system. The influence of type of acidulant, addition of various salts, concentration, and preheat treatment on aggregation of casein micelles in the cold was studied. It was observed that skim milk and concentrated skim milk acidified with GDL formed a gel at $\mathrm{pH} 4.8$ and lower. Skim milk acidified with $\mathrm{HCl}$ had to reach a $\mathrm{pH}$ of 4.5 before casein aggregation occurred. Differences in shear during aggregation or in acidification rate were not responsible for the observed difference in $\mathrm{pH}$ of aggregation. It was observed that the $\mathrm{pH}$ of aggregation was related to the divalent cation activity. Skim milk acidified with GDL had a markedly lower calcium ion activity than skim milk acidified with $\mathrm{HCl}$, probably due to association of calcium with gluconate ions. Increasing the divalent cation activity of skim milk prior to acidification with GDL resulted in a decrease in firmness of the acidified skim milk gels. The same observations were found for preheated skim milk. The observed influence of divalent cations on the aggregation of micelles in the cold are hard to explain. It was postulated that a high divalent cation concentration could prevent the hairy layer, which sterically stabilizes the micelles, against collapse, possibly by crosslinking protruding peptide chains.

The ice cream plasma studied in this work is a model ice cream plasma. In real hardened ice cream, the temperature is lower, the plasma is more concentrated and stabilizers are present. It is assumed that as a result of a further decrease in temperature to e.g. $-18^{\circ} \mathrm{C}$, which also results in a further concentration of the plasma, the properties of the micelles will not change very much. However, the presence of stabilizers may have an effect. Thermodynamic incompatibility may result, which then can, in principle, induce phase separation. This might result in a phase rich in casein. In conclusion, although the system studied differs from real ice cream plasma, this study provides a sound knowledge base for understanding and influencing the role of casein in the physical properties of ice cream. 


\section{Samenvatting}

IJs is een populair toetje en snack dat in verschillende vormen al honderden jaren gegeten wordt. In Nederland wordt tegenwoordig jaarlijks circa 7,5 liter ijs per hoofd van de bevolking geconsumeerd. Zo'n $70 \%$ hiervan is industrieel bereid ijs. De markt voor dit ijs is erg dynamisch. Productintroducties en -verbeteringen zijn aan de orde van de dag. Om dit te kunnen realiseren moet de industrie onder andere een gedegen kennis van de eigenschappen van het product hebben. De kwaliteitseigenschappen van ijs worden vooral bepaald door de procesvoering en de samenstelling. Vanuit wetenschappelijk en technologisch oogpunt is roomijs een gecompliceerd product; er worden diverse processen toegepast, er worden veel verschillende ingrediënten gebruikt en het uiteindelijke product heeft een ingewikkelde structuur. De processen die gebruikt worden zijn: mengen van ingrediënten, pasteuriseren, homogeniseren, koelen en "rijpen"(= enige tijd koud bewaren), tegelijkertijd vriezen en lucht inslaan, verpakken, harden ( $=$ bewaren bij zeer lage temperatuur, bv $-30^{\circ} \mathrm{C}$ ) en koud bewaren. Roomijs bevat water (bv $63.5 \%$, grotendeels bevroren), bestanddelen uit magere melk $(11 \%)$, melkvet $(10 \%)$, sacharose $(15 \%)$ en hulpstoffen zoals verdikkingsmiddelen, emulgatoren, kleur- en smaakstoffen. IJs is een vast schuim van luchtbellen. Het schuim wordt gedeeltelijk gestabiliseerd door geklonterde vetbolletjes en door ijskristallen. Luchtbellen, vetbolletjes en ijskristallen zijn gedispergeerd in een geconcentreerde waterige oplossing die suikers, eiwitten, zouten, verdikkingsmiddelen etc. bevat. Deze laatste fase noemen we ijsplasma.

Omdat de meeste ijsproducten op basis van melk gemaakt worden bevatten ze melkeiwitten. Ongeveer $80 \%$ van het melkeiwit bestaat uit caseîne, die weer een mengsel is van 4 verschillende groepen eiwitten. De rest bestaat voornamelijk uit serumeiwitten, vaak ook wei-eiwitten genoemd. In melk komt caseïne voornamelijk voor in de vorm van caseïnemicellen. Dit zijn volumineuze aggregaten van eiwit en calciumfosfaat met een diameter van 50-300 nm. Dit onopgeloste calciumfosfaat is in dynamisch evenwicht met opgelost calcium en fosfaat in het serum van melk. De eigenschappen van caseïnemicellen zijn van groot belang voor de fysische eigenschappen van vele zuivelproducten, zoals bijvoorbeeld de viscositeit van yoghurt en de stremeigenschappen van melk voor de bereiding van kaas. Er is veel bekend over de eigenschappen van caseïnemicellen in melk. Dit is echter niet het geval onder omstandigheden als in ijs. Wat bekend is is dat caseïne op drie plaatsen in ijs aanwezig is: op het grensvlak lucht-plasma, op het grensvlak vet-plasma en in het plasma. De drie belangrijkste functies van caseïne in ijs zijn waarschijnlijk: werkzaam zijn als emulgator tijdens het homogeniseren en als schuimmiddel tijdens het vriezen, en het verhogen van de viscositeit van ijsplasma. Met behulp van de kennis van caseïnemicellen in melk kunnen de eigenschappen van caseïnemicellen in ijs niet voorspeld worden. Omdat deze wel van belang kunnen zijn voor de eigenschappen van het product, is het doel van dit onderzoek het onderzoeken en begrijpen van de samenstelling en stabiliteit van caseïnemicellen onder omstandigheden als in ijsplasma. 
Voor het uitgevoerde onderzoek is een model ijsplasma ontwikkeld. De bereiding is hierbij zoveel mogelijk gelijk aan die van roomijs gehouden. Omdat alleen ijsplasma onderzocht werd was het niet nodig vet en lucht toe te voegen. Ook zijn geen hulpstoffen toegevoegd. Vanuit praktisch oogpunt was het niet mogelijk om plasma te bereiden en te onderzoeken bij $-18^{\circ} \mathrm{C}$ en werd gekozen voor een temperatuur van $-10^{\circ} \mathrm{C}$. De eerste stappen van de bereiding zijn als volgt: oplossen van mager melkpoeder en suiker in water, een nacht rijpen bij $5^{\circ} \mathrm{C}$, vriezen zonder lucht in te slaan in een schrapende warmtewisselaar, bewaren bij $-10^{\circ} \mathrm{C}$. Het mengsel bevat nu naast ijsplasma ook ijs- en lactosekristallen. Het ijsplasma werd vervolgens met behulp van een speciale pers uit het ijs geperst. De globale samenstelling van het plasma was als volgt: water $42,3 \%$, sacharose $38,4 \%$, lactose $4,6 \%$, caseïne $8,4 \%$, calcium $0,38 \%$ en fosfaat $0,31 \%$.

In ijsplasma werd onder meer de zoutverdeling over de serum en de micellaire fase, en de grootteverdeling en de voluminositeit van de caseïnemicellen bepaald bij $-10^{\circ} \mathrm{C}$. Om het gehalte zouten in het serum (ijsplasma zonder caseïnemicellen) te kunnen bepalen werd serum verkregen door ultrafiltratie van ijsplasma. De grootteverdeling van de micellen werd bepaald door het meten van de grootte van micellen op elektronenmicroscopische opnames. De voluminositeit van de micellen werd door middel van viscositeitsmetingen bepaald.

In het eerste gedeelte van het onderzoek is gekeken naar de eigenschappen van de caseïnemicellen in het ijsplasma. Elektronenmicroscopische foto's lieten zien dat, net als in melk, caseïne in ijsplasma in de vorm van micellen en submicellen voorkomt. Vergeleken met melk waren er echter minder submicellen en kleine micellen aanwezig. Voor de aantalgemiddelde diameter $d_{10}$ werd een waarde gevonden van $39 \mathrm{~nm}$ en voor de volume/oppervlakte-gemiddelde diameter $d_{\mathrm{vs}} 101 \mathrm{~nm}$. In de literatuur wordt in melk een $d_{10}$ van $25 \mathrm{~nm}$ en een $d_{\mathrm{vs}}$ van $86 \mathrm{~nm}$ vermeld. De toename in grootte zou een gevolg kunnen zijn van het zwellen of van het versmelten van micellen. De voluminositeit van de micellen in ijsplasma was $4,0 \mathrm{ml} / \mathrm{g}$. Aangezien deze ongeveer hetzelfde was als in melk werd geconcludeerd dat de toename in grootte van de micellen waarschijnlijk veroorzaakt wordt door versmelten van de micellen. Vergeleken met melk was een iets grotere hoeveelheid zouten in ijsplasma geassocieerd met caseinemicellen. Alhoewel de omstandigheden in ijsplasma zo extreem zijn, lijken de structuur en samenstelling van caseïnemicellen dus niet veel van die in melk te verschillen. De eigenschappen van caseïnemicellen in ijsplasma kunnen verklaard worden door ijsplasma als geconcentreerde melk bij een lage temperatuur te beschouwen. Concentreren van melk heeft een toename van de grootte van micellen en een toename van het calcium en fosfaat in de micellen tot gevolg. Verlagen van de temperatuur heeft echter tot gevolg dat een gedeelte van het calciumfosfaat in de micellen oplost en het aantal kleine micellen en submicellen toeneemt. Het lijkt er dus op dat in ijsplasma bij $-10^{\circ} \mathrm{C}$ deze twee invloeden elkaar globaal opheffen. Als ijsplasma bewaard wordt bij kamertemperatuur en er ten opzichte van melk dus alleen het concentratie-effect een rol speelt, neemt de hoeveelheid calcium en citraat in het serum dan ook fors af. 
Aangezien alle ijsmix gepasteuriseerd wordt, is in het tweede gedeelte van het onderzoek gekeken naar de invloed van voorverhitten op eigenschappen van caseïnemicellen in ijsplasma. Hiertoe werd bij de bereiding de ijsmix gedurende 30 minuten bij $90^{\circ} \mathrm{C}$ verhit. Door deze verhitting was bijna al het serumeiwit gedenatureerd. Uit het toepassen van een verhitting bij een lagere temperatuur $\left(30\right.$ minuten $\left.74^{\circ} \mathrm{C}\right)$ bleek dat denaturatie van serum eiwit in ijsmix langzamer verloopt dan in melk. Dit kan waarschijnlijk verklaard worden door de hogere concentratie aan opgeloste stoffen (vooral suikers en zouten). Het percentage calcium en fosfaat in het serum en de voluminositeit van caseïnemicellen werden niet beïnvloed door de voorverhitting. Vergeleken met het onverhitte ijsplasma was echter $d_{10}$ kleiner en $d_{v s}$ groter in voorverhit ijsplasma. De afname in $d_{10}$ zou verklaard kunnen worden door de vorming van eiwitaggregaten gedurende de verhitting of doordat het versmelten van caseïnemicellen gehinderd wordt door de hitte geïnduceerde associatie van serumeiwit met caseïnemicellen. De toename in $d_{v s}$ zou veroorzaakt kunnen worden door een toename van de grootte van de micellen door de hitte geïnduceerde associatie van serumeiwit met caseïnemicellen en/of door hittecoagulatie. Om meer inzicht te krijgen in de veranderingen die plaatsvinden tijdens verhitten en concentreren is de invloed van deze factoren in magere melk onderzocht. Meer inzicht in het mechanisme werd hier echter niet mee verkregen.

Yoghurtijs is een bekende ijssoort. Een van de kenmerken van yoghurtijs is dat het een lage $\mathrm{pH}$ heeft. Om het effect van een $\mathrm{pH}$-verlaging op de eigenschappen van caseïnemicellen in ijsplasma te onderzoeken, werd door middel van het toevoegen van melkzuur de pH van de ijsmix verlaagd naar 4,0. Een pH-verlaging in melk leidt tot oplossen van het calciumfosfaat en aggregatie van de caseïnemicellen. Zoals verwacht is daarom in yoghurtijsplasma bijna al het calcium en anorganisch fosfaat aanwezig in het serum. Op electronenmicroscopische opnames werden aggregaten van caseïne in het plasma waargenomen. Het yoghurtijsplasma was na de persstap een zeer viskeuze vloeistof en het vormde bij bewaren bij $-10^{\circ} \mathrm{C}$ een gel. Dit betekent hoogstwaarschijnlijk dat een netwerk van caseïne aanwezig was. $\mathrm{Na} 10$ maanden bewaren werden scheuren in het gel waargenomen. De reologische eigenschappen van het plasma waren ook veranderd. De veranderingen in het gel zouden veroorzaakt kunnen zijn door een enzym, een zuur protease, dat de caseïne in brokstukken knipt. Aangezien geen degradatieproducten van caseine in het yoghurtplasma gevonden werden, is deze verklaring niet erg waarschijnlijk. Het is waarschijnlijk zo dat er een herrangschikking van het eiwitnetwerk heeft plaats gevonden. Dit gebeurt ook in andere caseïnegelen en kan bijvoorbeeld leiden tot vochtuitstoting (synerese) van een gel.

Omdat bij het verzuren van yoghurt ijsmix interessante waarnemingen werden gedaan, is in het laatste gedeelte van het onderzoek gekeken naar de invloed van aggregatie van caseïnemicellen in de kou. Als systeem werd hiervoor (geconcentreerde) gereconstitueerde, magere melk gekozen. Vrijwel alle experimenten in dit gedeelte van het onderzoek werden bij $4^{\circ} \mathrm{C}$ uitgevoerd een week na het toevoegen van het zuur. Als melk en geconcentreerde meik verzuurd werden met GDL (glucono- $\delta$-lacton) vormden ze een gel bij pH 4,8 en lager. Als 
melk echter met zoutzuur verzuurd werd, werden pas aggregaten gevonden bij pH 4,5, en wel in de vorm van een neerslag. Drie mogelijke verklaringen voor het verschil in $\mathrm{pH}$ van aggregatie zijn bestudeerd. De eerste hypothese was dat het verschil veroorzaakt werd doordat bij verzuring met zoutzuur geroerd werd en dat verzuring met GDL in rust plaatsvond. De tweede hypothese was dat monsters met GDL langzaam verzuurd werden en die met zoutzuur snel. Deze beide verklaringen konden echter weerlegd worden. De derde hypothese was dat de $\mathrm{pH}$ van aggregatie afhankelijk is van de activiteit (de effectieve concentratie) van tweewaardige kationen. Magere melk verzuurd met GDL had een veel lagere calciumionactiviteit dan melk verzuurd met zoutzuur. Waarschijnlijk werd dit veroorzaakt door binding van het calcium door gluconaationen. Het toevoegen van calcium en magnesiumionen aan de melk voor verzuren resulteerde dan ook in een afname van de stevigheid van de gelen. Het toevoegen van natriumionen had weinig effect. Dezelfde waarnemingen werden gedaan bij verzuring van voorverhitte melk in de kou. De waarnemingen zijn echter tegenovergesteld aan waarnemingen in de literatuur bij kamertemperatuur. Daar wordt gevonden dat een hogere calciumionactiviteit juist leidt tot stevigere gelen. Het effect van de activiteit van tweewaardige kationen op de aggregatie van caseïnemicellen in de kou is dan ook moeilijk te verklaren. Twee hypotheses zijn hiervoor gegeven.

Alhoewel in dit proefschrift gebruik gemaakt is van een model van ijsplasma, heeft het onderzoek een basis gelegd voor de kennis van de eigenschappen van caseïnemicellen in ijsplasma. Met deze kennis kan het gedrag van caseïne in de plasma van ijs begrepen en gestuurd worden. 
Het is zover .... het boekje is eindelijk af? Tussen de start van het onderzoek en de verschijning van dit proefschrift ligt een lange tijd. Mijn echte aio-tijd lijkt dan ook al lang geleden. Als ik op deze periode terugkijk, denk ik aan een erg koude, maar vooral leerzame en gezellige tijd. Een tijd die ik niet graag had willen missen! Veel mensen hebben een bijdrage geleverd aan het proefschrift. Een aantal van hen wil ik hier graag in het bijzonder bedanken.

Allereerst wil ik mijn promotor, Pieter Walstra, en mijn co-promotor Tiny van Boekel bedanken. Pieter, jouw enorme kennis op veel verschillende gebieden heeft mij elke keer weer versteld doen staan. Daarnaast heb ik veel geleerd van jouw manier van werken. Tiny, bedankt voor het vertrouwen en de ruimte die je me gaf. Naast Pieter en Tiny heeft ook Ton van Vliet een grote bijdrage geleverd. Ton, met name je hulp bij het werk aan aggregatie van caseïnemicellen in de kou is van grote waarde geweest.

I am very grateful to Unilever Research Colworth House for financing this project, for providing the facilities for doing part of the experiments and for sharing knowledge on ice cream with me. In my opinion it is an excellent example of how industry and universities can cooperate on research. I am grateful in particular to Don Darling for initiating the project and helping to decide on the direction of the project. Much appreciation goes to Deryck Cebula for all his help and enthusiasm at every stage of the project. I would like to thank Jennie Brigham and Colin Smith for making the electron micrographs. Barbara Pelan wil ik bedanken voor de discussies en de gezelligheid tijdens mijn bezoeken aan Colworth. Babs, ik vind het dan ook erg leuk dat je mijn paranimf wilt zijn!

Voor het praktische werk zijn Henk van der Stege en Maria Baltussen onmisbaar geweest. Henk, jij hebt me enorm geholpen met het geschikt maken van de votator voor jjsbereiding, de bereiding van het ijs en alle praktische zaken in het vrieslab. Ik ben blij dat ook jij mijn paranimf wilt zijn. Maria, bedankt voor je inzet bij alle chemische analyses.

In het kader van een afstudeervak of Erasmus-stage hebben Ingrid Muis, Hans Voogt, Clare Brooks, Rachel Cow, Eldert Bruinink en Martijn de Vries hun steentje bijgedragen aan dit proefschrift. Jan van Iersel heeft daarnaast in het kader van een NOP-project vier maanden aan het project gewerkt. Bedankt voor het vele werk en voor de leuke samenwerking!

Door de (aio-)collega's op het lab werd deze tijd ook een erg gezellige tijd. Ik zal de borrels, de 208 projects, het aio-reisje, de vierdaagse, international diners, de vele discussies ("mannen....!"), de saunabezoeken etc. niet snel vergeten. Mijn twee kamergenootjes Vesna en William wil ik speciaal noemen. Jullie zijn deze jaren echte vrienden geworden. Ik hoop dat onze kameretentjes nog jaren doorgaan. Het één na laatste 208 project is nu afgerond!

Paps en mams, ik wil speciaal jullie op deze plaats graag bedanken voor jullie grote betrokkenheid en steun. Dit is voor mij altijd een enorme stimulans geweest. Last, but not least, Peter. Bedankt voor al je geduld en support! Onze vakanties worden nu weer echte vakanties, onze weekenden gaan weer echte weekenden worden. Dat wordt nog meer genieten!

Margrethe 


\section{Curriculum vitae}

Margrethe Jeanette Jonkman was born on the 17th of January 1969 in Ulrum, the Netherlands. In 1987 she finished secondary school (Gymnasium B) at Christelijk Lyceum in Zeist. In September 1987 she started her study in Food Science at Wageningen University. The main topics during her study were process engineering and food physics. She spent her practical training period at the Indian Institute of Technology in Kharagpur, India. In June 1993 she graduated "cum laude".

From July 1993 till October 1998 she worked as a PhD-candidate at the Department of Food Science of Wageningen University. During this period, she performed the research described in this thesis. The research was done in co-operation with Unilever Research Colworth, United Kingdom. For two years she was a member of the University Council.

Since September 1997 she has been working for Friesland Coberco Dairy Foods. First she worked as a research scientist protein at the Research Centre in Deventer. From July 2000 she is manager R\&D of the operating company Friesche Vlag. 